\title{
Modelling the influence of biotic plant stress on atmospheric aerosol particle processes throughout a growing season
}

\author{
Ditte Taipale $^{1,2,3,4}$, Veli-Matti Kerminen ${ }^{1}$, Mikael Ehn ${ }^{1}$, Markku Kulmala ${ }^{1}$, and Ülo Niinemets ${ }^{2}$ \\ ${ }^{1}$ Institute for Atmospheric and Earth System Research/Physics, Faculty of Science, \\ University of Helsinki, P.O. Box 64, 00014 Helsinki, Finland \\ ${ }^{2}$ Institute of Agricultural and Environmental Sciences, Estonian University of Life Sciences, \\ Kreutzwaldi 1, Tartu 51006, Estonia \\ ${ }^{3}$ Institute for Atmospheric and Earth System Research/Forest Sciences, Faculty of Agriculture and Forestry, \\ University of Helsinki, P.O. Box 27, 00014 Helsinki, Finland \\ ${ }^{4}$ Hyytiälä Forestry Field Station, Hyytiäläntie 124, 35500 Korkeakoski, Finland
}

Correspondence: Ditte Taipale (ditte.taipale@ @elsinki.fi)

Received: 17 February 2021 - Discussion started: 12 March 2021

Revised: 3 October 2021 - Accepted: 30 October 2021 - Published: 1 December 2021

\begin{abstract}
Most trees emit volatile organic compounds (VOCs) continuously throughout their life, but the rate of emission and spectrum of emitted VOCs become substantially altered when the trees experience stress. Despite this, models to predict the emissions of VOCs do not account for perturbations caused by biotic plant stress. Considering that such stresses have generally been forecast to increase in both frequency and severity in the future climate, the neglect of stress-induced plant emissions in models might be one of the key obstacles for realistic climate change predictions, since changes in VOC concentrations are known to greatly influence atmospheric aerosol processes. Thus, we constructed a model to study the impact of biotic plant stresses on new particle formation and growth throughout a full growing season. We simulated the influence on aerosol processes caused by herbivory by the European gypsy moth (Lymantria dispar) and autumnal moth (Epirrita autumnata) feeding on pedunculate oak (Quercus robur) and mountain birch (Betula pubescens var. pumila), respectively, and also fungal infections of pedunculate oak and balsam poplar (Populus balsamifera var. suaveolens) by oak powdery mildew (Erysiphe alphitoides) and poplar rust (Melampsora larici-populina), respectively. Our modelling results indicate that all the investigated plant stresses are capable of substantially perturbing both the number and size of aerosol particles in atmospherically relevant conditions, with increases in the amount of newly formed particles by up to about an order of magnitude
\end{abstract}

and additional daily growth of up to almost $50 \mathrm{~nm}$. We also showed that it can be more important to account for biotic plant stresses in models for local and regional predictions of new particle formation and growth during the time of infestation or infection than significant variations in, e.g. leaf area index and temperature and light conditions, which are currently the main parameters controlling predictions of VOC emissions. Our study thus demonstrates that biotic plant stress can be highly atmospherically relevant. To validate our findings, field measurements are urgently needed to quantify the role of stress emissions in atmospheric aerosol processes and for making integration of biotic plant stress emission responses into numerical models for prediction of atmospheric chemistry and physics, including climate change projection models, possible.

\section{Introduction}

Formation and subsequent growth of atmospheric aerosol particles is globally a major source of cloud condensation nuclei (CCN) (Spracklen et al., 2008; Merikanto et al., 2009; Dunne et al., 2016). CCN impact various cloud processes, such as cloud formation, albedo and lifetime (Twomey, 1977; Albrecht, 1989; Makkonen et al., 2009; Kerminen et al., 2005), and atmospheric aerosol particles are thereby able to influence our climate indirectly, in addition to interacting 
directly with incoming solar radiation. Though atmospheric aerosol particles provide the single largest cooling effect on our climate, they are also connected with the greatest uncertainty in climate change projections (IPCC, 2013). Part of this uncertainty is caused by limited knowledge about the aerosol precursor molecules.

Oxidation products of certain volatile organic compounds (VOCs) participate in both the formation of new particles (Donahue et al., 2013; Schobesberger et al., 2013; Kulmala et al., 2014; Riccobono et al., 2014; Kirkby et al., 2016; Tröstl et al., 2016) and growth of existing particles via gas-toparticle condensation (Riipinen et al., 2012; Ehn et al., 2014; Bianchi et al., 2019). Globally, and especially in forested regions, the majority of these organic compounds originate from terrestrial vegetation (Kanakidou et al., 2005; Jimenez et al., 2009). Thus, increases in the emissions of certain biogenic VOCs can lead to enhanced formation of atmospheric aerosol particles and subsequently to a rise in $\mathrm{CCN}$ concentration (Kerminen et al., 2012; Paasonen et al., 2013).

Many plants emit VOCs constitutively; i.e. they emit VOCs regardless of the experience of stress. Biotic plant stress (i.e. stress caused to a plant by living species such as herbivores and pathogens) is known to substantially alter both the rates of emission and spectrum of VOCs emitted constitutively (Holopainen and Gershenzon, 2010; Niinemets, 2010; Niinemets et al., 2013; Faiola and Taipale, 2020). For example, constitutively emitted isoprene, which is thought to suppress the formation of new atmospheric aerosol particles (Kiendler-Scharr et al., 2009, 2012; Lee et al., 2016; McFiggans et al., 2019; Heinritzi et al., 2020), is usually reduced in response to such stress (e.g. Brilli et al., 2009; Copolovici et al., 2014, 2017; Jiang et al., 2016), while the emissions of other VOCs are greatly increased. Emissions of VOCs which are increased or start to be emitted in response to plant stress are referred to as induced volatile plant emissions. A large fraction of stress-induced compounds (e.g. monoterpenes, sesquiterpenes, 4,8-dimethyl1,3,7-nonatriene (DMNT), and methyl salicylate) have a high potential to produce and grow atmospheric aerosol particles (e.g. Mentel et al., 2013; Joutsensaari et al., 2015; Yli-Pirilä et al., 2016; Ylisirniö et al., 2020), while other induced compounds (e.g. methanol and lipoxygenase oxidation products (LOX), which mostly include $\mathrm{C}_{6}$ aldehydes, alcohols, and esters) are anticipated to suppress aerosol processes (e.g. Mentel et al., 2013).

While much attention has been given to representing constitutive emissions of VOCs in numerical models, VOC emissions caused by stress, and biotic stress in particular, have been mostly excluded (Grote et al., 2013; Faiola and Taipale, 2020), despite the fact that biotic plant stress is largely ubiquitous. This is mainly due to a lack of measurements, combined with the fact that variations in emission responses are highly stressor specific (e.g. Holopainen and Gershenzon, 2010; Niinemets, 2010; Faiola and Taipale, 2020). Thus, no consistent mechanism for the emissions of VOCs from plants under stress exists. Though the most extensively used biogenic emissions model, MEGAN (Guenther et al., 2012), considers a stress emission category, the treatment is not quantitative. The emission factor for stress VOCs is, for example, the same for all plant functional types and is supposed to represent a large range of different types of stresses. Recently, Grote et al. (2019) proposed a new modelling framework for estimating emissions of VOCs induced by both biotic and abiotic plant stresses, while Douma et al. (2019) developed a model to predict both the emissions and concentrations of stress-induced VOCs, which was parameterised to simulate a black poplar canopy infested by gypsy moths. Both are promising tools, but in their current states they exclude important storage emissions that are usually released upon wounding (e.g. Blande et al., 2009; Faiola et al., 2018; Kari et al., 2019), and they do not fully (Grote et al., 2019) consider - or take into account at all (Douma et al., 2019) how the constitutive emissions of isoprene are modulated. This is as such understandable considering that emissions of isoprene might be either reduced (e.g. Brilli et al., 2009; Copolovici et al., 2017) or increased (e.g. Schaub et al., 2010; Ye et al., 2019) in response to biotic plant stress, but this is nevertheless problematic since isoprene is globally the VOC that is emitted in the largest quantities (Guenther et al., 2012) and is thought to suppress the formation of aerosol particles (see above). Whilst Grote et al. (2019) assumed a linear response to the degree of damage, which has been shown not always to be true, especially at severe stress levels (e.g. Niinemets et al., 2013; Jiang et al., 2016; Yli-Pirilä et al., 2016; Copolovici et al., 2017; Faiola and Taipale, 2020), it is not obvious how the model results by Douma et al. (2019) depend on the degree of damage, as they operate with "number of larvae" rather than a stand level of defoliation. Additionally, Grote et al. (2019) did not account for an explicit dependency of the emissions on temperature, which is usually considered as one of the most important environmental parameters for emissions of VOCs (e.g. Grote et al., 2013). Common for both studies is that they only simulate rather short timescales (i.e. a few days).

Since measurements have clearly illustrated that biotic plant stress is able to significantly influence the amount and size of formed atmospheric aerosol particles over short periods at least (Mentel et al., 2013; Joutsensaari et al., 2015; Yli-Pirilä et al., 2016; Faiola et al., 2018, 2019) via perturbations in VOC emissions, there is an urgent need to quantify the atmospheric importance of biotic plant stress. This need is amplified by the fact that insect outbreaks and fungal diseases generally are expected to increase in both frequency and severity in the future (Cannon, 1998; Bale et al., 2002; Harrington et al., 2007; Pautasso et al., 2012; Boyd et al., 2013). Unfortunately, such quantitative estimates are currently very scarce, connected with a large degree of uncertainty, and not necessarily reaching the same conclusions. For example, Berg et al. (2013) used bark beetle-induced monoterpene emission responses and several years of bark 
beetle-induced tree mortality data from western North America as input to a global model in order to investigate the impact of bark beetle attacks on regional secondary organic aerosol (SOA) formation. The authors found that the concentration of SOA might increase regionally by up to $40 \%$ or $300 \%$ in cases of bark beetle attacks on lodgepole pine and spruce trees, respectively (Berg et al., 2013). At the same time, Berg et al. (2013) concluded that the enhancement in the concentrations of SOA is in most cases small in comparison to the impact of wildfires on total organic aerosol in western North America. Bergström et al. (2014), on the other hand, used a regional chemical transport model to simulate the impact of de novo emissions induced by aphid infestation on SOA formation and estimated that these induced emissions currently account for $20 \%-70 \%$ of total biogenic SOA in northern and central European forests. Meanwhile, Joutsensaari et al. (2015) calculated a local increase of up to $480 \%$ in aerosol mass and $45 \%$ in $\mathrm{CCN}$ concentration, when it was assumed that $10 \%$ of the boreal forest area experienced stress which increased constitutive monoterpenes emission rates by an order of magnitude. Using satellite observations, Joutsensaari et al. (2015) also found a 2-fold increase in aerosol optical depth over Canadian pine forests during a bark beetle outbreak. Thus, the degree of necessity of considering biotic plant stress emissions for predictions of new particle formation in the atmosphere is still uncertain, and therefore there is a great need for field observations of different scales to constrain and quantify the role of stress emissions in SOA formation but also for innovative model approaches that improve the quantitative representation of the emissions. To our knowledge, no one has previously considered the dynamics of insect herbivory when simulating the emitted VOCs and produced and grown aerosols from stressed plants. Additionally, there has so far been no attempt to measure or model the impact of pathogenic infections on atmospheric aerosol processes.

We constructed a conceptual model to investigate the atmospheric impacts of biotic plant stresses. We used this model to simulate formation and growth of atmospheric aerosol particles throughout a growing season in pure oak, poplar, and birch forest stands in stress-free conditions and under herbivory or fungal stress. By considering the dynamics of insect herbivory and pathogenic infections in combination with seasonal changes in environmental parameters, our aim was to contribute to a discussion about whether biotic plant stress perturbs atmospheric aerosol processes sufficiently to warrant their inclusion in larger-scale models.

\section{Materials and methods}

We constructed a OD box model that includes modules for emissions of VOCs from stress-free and biotically stressed tree species (Sect. 2.4), boundary layer meteorology (Sect. 2.5), atmospheric chemistry (Sect. 2.6), and aerosol dynamics (Sect. 2.7). The calculated canopy VOC emissions from biotically stressed trees depend on the dynamics of the biotic stressors of interest (Sect. 2.1 and 2.2) and changes in the leaf area index (Sect. 2.3). The model is programmed in Fortran and the time step for each module is $60 \mathrm{~s}$. The model was simulating $1 \mathrm{~d}$ at a time. The purpose of our study was to simulate the influence of low-volatility organic compounds on the evolution of aerosol number size distribution via new particle formation and subsequent particle growth. Thus, we were interested in changes in the nucleation mode dynamics, and not in aerosol mass concentration. The individual processes included in the model (Sect. 2.1-2.7) are aimed to imitate our best mechanistic understanding of those processes. The descriptions of several of the individual processes have been evaluated separately in earlier studies by either us or by other researchers (following the references provided in the sections below). The model's ability to reproduce the influence of organic compounds on aerosol formation and growth in biotically stress-free conditions has furthermore been tested by constraining and validating the model with observations from the SMEAR II station (the Station for Measuring Ecosystem-Atmosphere Relations II) in Hyytiälä, Finland (Taipale, 2021).

\subsection{Simulations of larval infestation dynamics}

Whereas mountain birch (Betula pubescens var. pumila; former spp. czerepanovii, Fig. 1c) is the main host for autumnal moths (Epirrita autumnata, Fig. 1g, Klemola et al., 2004; Ammunét et al., 2011), European gypsy moth (Lymantria dispar, Fig. 1d) is one of the major defoliating insects feeding on pedunculate oak (Quercus robur, Fig. 1a, https://www. cabi.org/isc/datasheet/31807\#tohostsOrSpeciesAffected, last access: 11 June 2021). The larval eggs of both moths hatch in spring synchronously with bud burst (Kaitaniemi et al., 1997; Kaitaniemi and Ruohomäki, 1999; Spear, 2005; McManus et al., 1989). Both sexes have five larval stages (instar), though female gypsy moths have six. These stages are separated by periods of molting where the larvae do not feed. A complete defoliation of vast areas can occur within 4-6 weeks by autumnal moth (Kaitaniemi and Ruohomäki, 1999) and within 6-8 weeks by gypsy moth (McManus et al., 1989). Several thousands of square kilometres of birch forests have previously been reported to become defoliated due to just a single outbreak of autumnal moth in Fennoscandia (Tenow, 1975; Nikula, 1993), while gypsy moth is estimated to have defoliated $>95$ million acres of forest in North America alone during the years 1920 to 2020 (Coleman et al., 2020). Adults do not feed on leaves (Tammaru et al., 1996; Waring and Townsend, 2009). For simulations of mountain birch infested by autumnal moth, our model incorporates atmospheric and ecological conditions observed at the Station for Measuring Ecosystem-Atmosphere Relations (SMEAR I, Fig. 1h), Värriö, eastern Finnish Lapland (e.g. Hari et al., 1994), due to the high data quality and availability, and since mountain birch 
infested by autumnal moth is common at the site (Hunter et al., 2014). In our simulations, bud burst occurs on 6 June, the subsequent full leaf state is attained on 10 June (dates are based on long-term observations from the station), and senescence onsets on 20 August (Gill et al., 2015). We assumed that the larvae feed for 5 weeks starting on 6 June and that they pupate on 11 July (Kaitaniemi and Ruohomäki, 1999). The larvae dynamics (i.e. relative leaf consumption and time spent in each larval stage) that are incorporated in our model are based on Lempa et al. (2004). For simulations of pedunculate oak infested by European gypsy moth, our model incorporates mainly atmospheric conditions observed at the Meteorological Observatory Hohenpeißenberg (e.g. Birmili et al., 2003) in rural southern Germany (Fig. 1h) since this station has been classified as a representative measurement location for central Europe (Naja et al., 2003), where oak is a very common species. In our simulations, bud burst occurs on 15 May, the subsequent full leaf state is attained $20 \mathrm{~d}$ later on 4 June, and senescence onsets on 20 September (Gill et al., 2015). Durations of the various developmental states of the larvae are based on Zúbrik et al. (2007), which is also in agreement with Stoyenoff et al. (1994). Though the length of the larval state of female larvae feeding on pedunculate oak is typically a few days longer than the total duration of the male larval state (e.g. Zúbrik et al., 2007), we did not differentiate between the two genders but utilised the length of the female larval state due to simplification and since the female is the main consumer (Miller et al., 1991). We assumed that the larvae feed for $41 \mathrm{~d}$ (Zúbrik et al., 2007) starting on 15 May and that they pupate on 25 June. The relative leaf consumption within the different larval stages is based on Kula et al. (2013). The ratio in relative leaf consumption between the fourth and fifth instar is also within the range that is reported by Stoyenoff et al. (1994) (where no other ratios were provided). We neglected periods of molting, as those are typically on the order of less than a day (Ayres and MacLean, 1987). We assumed that either $30 \%$ or $80 \%$ of the total leaf area in the forest stand was consumed by the end of the feeding period (Fig. 2a, b).

\subsection{Simulations of fungal infection dynamics}

Oak powdery mildew (Erysiphe alphitoides) is one of the main foliar diseases of pedunculate oak (Quercus robur) in Europe (Desprez-Loustau et al., 2011). Among the Melampsora species, Melampsora larici-populina is the most widespread poplar rust (Vialle et al., 2011). M. laricipopulina has five morphologically and functionally different spore stages during its life cycle, where the two first stages are retrieved on larch and the last three on poplar (Vialle et al., 2011). The pathogenic fungal infections do not decrease the leaf area of their victim, but as they cover the leaf, they absorb nutrients from the cells of the leaf (Glawe, 2008) and change the physiology of the leaf (e.g. Major et al., 2010; Voegele and Mendgen, 2003; El-Ghany et al., 2009). The severity and spread of fungal infections depend largely on weather and growth conditions (e.g. Åhman, 1998; Johansson and Alström, 2000; Covarelli et al., 2013), where especially high rainfall in the beginning of the summer greatly enhances both the severity and the onset of infection (Covarelli et al., 2013; Pinon et al., 2006). The onset of attack by oak powdery mildew is limited by its morphological development, hence the infection usually starts to appear between the end of June and August (in France; Marçais et al., 2009; Marçais and Desprez-Loustau, 2014; Bert et al., 2016). M. larici-populina has been observed to attack young poplar trees as early as June (in Italy, Covarelli et al., 2013), though generally the disease emerges between July and September (in France and Italy, Gérard et al., 2006; Covarelli et al., 2013). In our simulations, we assumed that both fungi started to infect their host on 1 August. In the case of $M$. larici-populina, we only simulated the attack on poplar as the host (and not larch). Populus balsamifera var. suaveolens was chosen as the poplar species due to the availability of suitable published VOC emissions measurements. Based on Bert et al. (2016), we assumed that the severity of infection increases linearly with time, starting on 1 August and ending on 20 September. We assumed that either $30 \%$ or $80 \%$ of the total leaf area in the forest stands was covered by fungi by the end of the growing season (Fig. 2c, d). For these simulations, our model incorporates the same atmospheric conditions as for simulations of oak infested by gypsy moth. Poplar bud burst occurs on 20 April in our model (Tripathi et al., 2016), and we assumed the same timing of senescence as for simulations of oak (Gill et al., 2015; Tripathi et al., 2016).

\subsection{Treatment of the leaf area index}

Low soil temperatures usually prevent growth of a second leaf flush in birch trees (Aphalo et al., 2006). Thus, we assumed that the leaf area index (LAI) of a non-infested mountain birch stand in Lapland increases linearly from 0$2.0 \mathrm{~m}^{2} \mathrm{~m}^{-2}$ (Dahlberg et al., 2004) in the time period 610 June (bud burst to full leaf), and stays constant until the onset of senescence (Fig. 3a). The LAI of an infested stand decreases proportionally with the level of defoliation (Fig. 3a). Refoliation only occurs in totally, or near-totally, defoliated mountain birch trees (Kaitaniemi et al., 1997). Hence, we assumed that the LAI of a heavily defoliated stand returns to $70 \%$ of the original LAI within 3 weeks of defoliation (Pekka Kaitaniemi, University of Helsinki, personal communication, 2018, Fig. 3a). Poplar trees produce leaves throughout the season, and we therefore assumed that the LAI of poplar stands increases quadratically from 20 April (bud burst) until 15 August (Fig. 3c, Tripathi et al., 2016). Oak, on the other hand, usually only produces one significant leaf flush, and hence we assumed that the LAI of oak stands increases with a sigmoid shape from 15 May (bud burst) until 4 June (full leaf state attained) (Fig. 3b, Oláh et al., 2012). In our simulations, the maximum LAI of poplar 


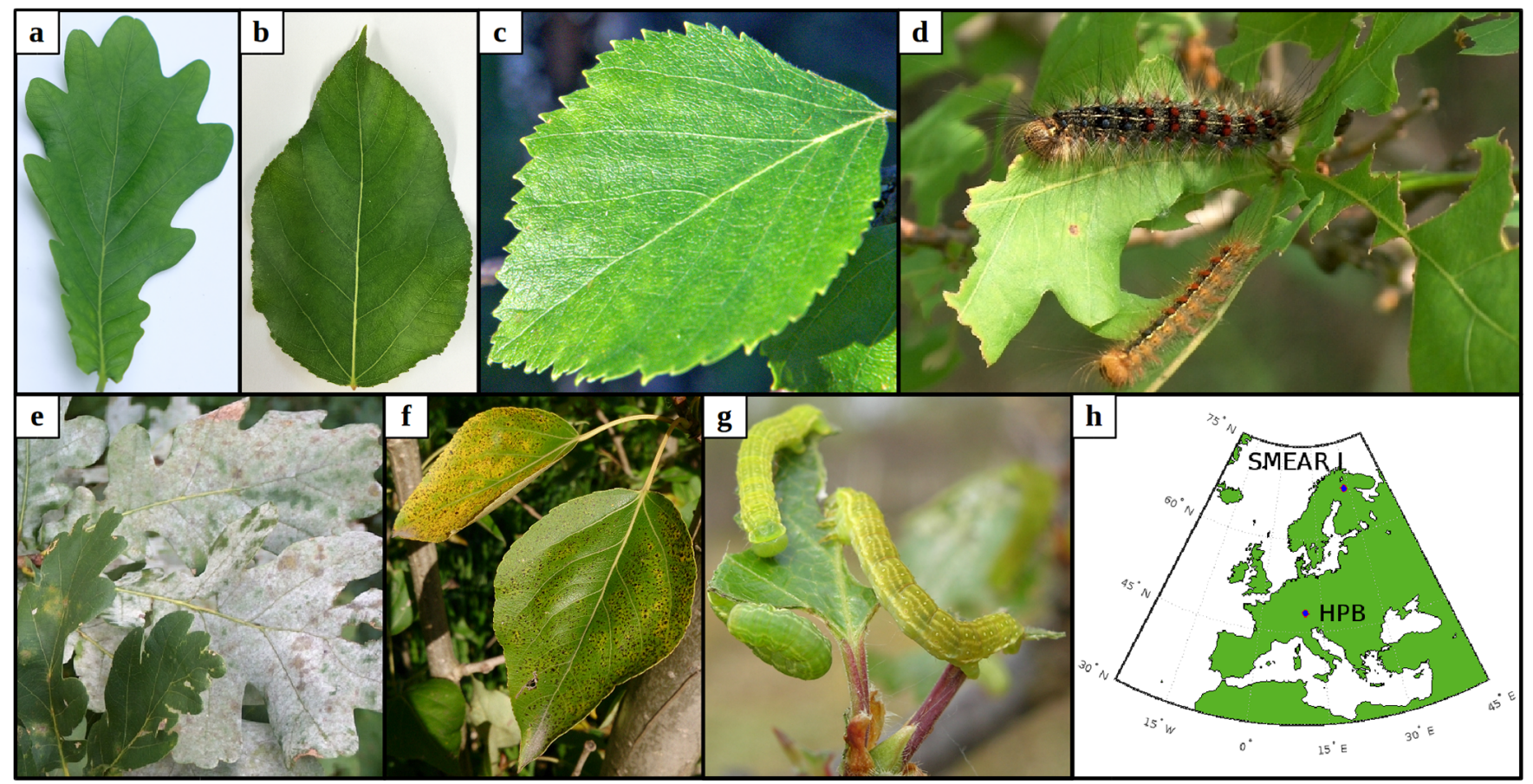

Figure 1. The plant species and biotic stresses we considered together with their locations. Panels (a-c) show examples of non-infected leaves of (a) pedunculate oak (Quercus robur), (b) balsam poplar (Populus balsamifera var. suaveolens), and (c) mountain birch (Betula pubescens var. pumila; former spp. czerepanovii). Panels (d-g) show fungal-infected or moth-infested leaves of pedunculate oak infested by (d) European gypsy moth (Lymantria dispar) or infected by (e) oak powdery mildew (Erysiphe alphitoides), (f) poplar infected by rust fungus (Melampsora larici-populina), and (g) mountain birch infested by autumnal moth (Epirrita autumnata). (h) Locations of the two sites that serve as boundary conditions in our simulations. Photos are provided courtesy of (a, c) Juho Aalto, (b) Yifan Jiang, (d, e) Haruta Ovidiu (University of Oradea, Bugwood.org), (f) Ülo Niinemets, and (g) Tero Klemola.

and oak is $5.0 \mathrm{~m}^{2} \mathrm{~m}^{-2}$. The LAI of an oak stand infested by gypsy moth decreases proportionally with the level of defoliation (Fig. 3b). The fungal infections do not decrease the leaf area of their host nor do they prevent the tree from producing multiple flushes of leaves (Marçais and Desprez-Loustau, 2014). The LAI might, however, in reality be less in an infected stand than in a non-infected stand, though this depends highly on the specific genotypes and their individual fungal resistance (Verlinden et al., 2013; Shifflett et al., 2016) but naturally also on the timing of infection. Since most summer leaves already appear before the onset of infection, we did not assume a decrease in LAI. Severe powdery mildew infection $(>50 \%)$ has been shown to greatly reduce the infected leaf lifespan (Hajji et al., 2009). The median time before shedding of deformed oak leaves has been estimated to be 10-31 d (Hajji et al., 2009). In our scenario of a heavily infected stand $(80 \%$ of the stand leaf area is infected by the end of the season), an infection level of $50 \%$ is reached on 1 September. Since senescence is assumed to onset on 20 September, we excluded an earlier shedding of leaves. Hence, in our simulations of fungal infections, we assumed that the LAI is the same as in a non-infected stand (Fig. 3b, c).

\subsection{Plant emissions of volatile organic compounds}

The plant emissions $\left(F_{i}\right)$ of individual VOCs $(i)$ from various pure stands were computed as follows:

$F_{i}=\varepsilon_{i} \times \mathrm{LAI} \times \gamma_{\mathrm{L}} \times \gamma_{\mathrm{T}}$,

where $\varepsilon_{i}$ is the emission rate of $i$ at standard conditions $\left(25^{\circ} \mathrm{C}, 1000 \mu \mathrm{mol} \mathrm{m}^{-2} \mathrm{~s}^{-1}\right)$, LAI is the one-sided leaf area index and treated as mentioned in Sect. 2.3, and $\gamma_{\mathrm{L}}$ and $\gamma_{\mathrm{T}}$ are the activity factors that account for changes in light and temperature from standard conditions. This expression is adopted from Guenther et al. (2012), Eqs. (1)-(2), when we assume that the soil moisture and ambient $\mathrm{CO}_{2}$ concentration in our stands are optimal. Generally, we excluded the effect of leaf age on the emissions of VOCs, since we do not know the effect of leaf age on stress-induced emissions. However, we also tested whether the impact of leaf maturity would be able to change the conclusions of our study when making certain assumptions about the leaf age effect. The treatment of the leaf age effects and the results of these tests are presented in Appendix B and discussed in Sect. 3.2.

Similarly to, e.g. Simpson et al. $(1999,2012)$ and Bergström et al. (2014), we utilised a simple non-canopy approach, where ambient and leaf temperature are assumed 

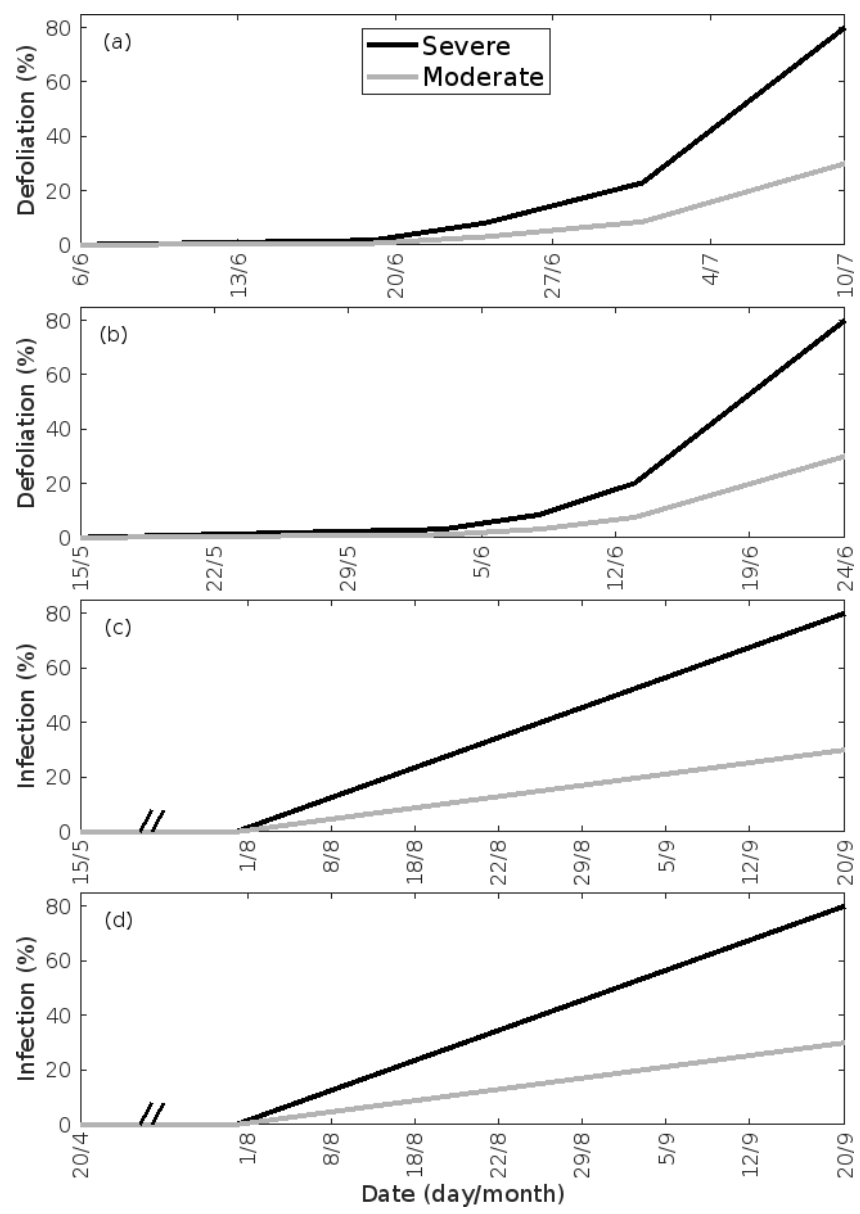

Figure 2. Infection dynamics. (a) Birch infested with autumnal moth larvae, (b) oak infested with European gypsy moth larvae, (c) oak infected by oak powdery mildew, and (d) poplar infected by rust fungus. The infection dynamics of oak powdery mildew and rust fungus are assumed to be similar, but the duration of growth of the two tree species is different. The dynamics are specific to the locations of Lapland (a) and central Europe (b-d). A total of $30 \%$ (moderate infection scenario) or $80 \%$ (severe infection scenario) of the total leaf area in the forest stands is assumed to be consumed by the end of the feeding period or infected by fungi by the onset of senescence. Note the different time axes.

to be equal and where the use of branch-level emission factors accounts for the canopy shading effect (Guenther et al., 1994). We utilised emission rates, reported as a function of the degree of damage, from Copolovici et al. (2017, 2014), Jiang et al. (2016), and Yli-Pirilä et al. (2016). The emission rates reported by Copolovici et al. $(2017,2014)$ and Jiang et al. (2016) were all retrieved by leaf-level measurements, and hence we decreased the reported emission rates by a factor of 0.57 , since branch-level emission factors for lightsensitive emissions are typically a factor of 1.75 smaller than the corresponding leaf-level values (Simpson et al., 1999, 2012). We did not decrease the emission rates reported by Yli-Pirilä et al. (2016), since these were based on measure-
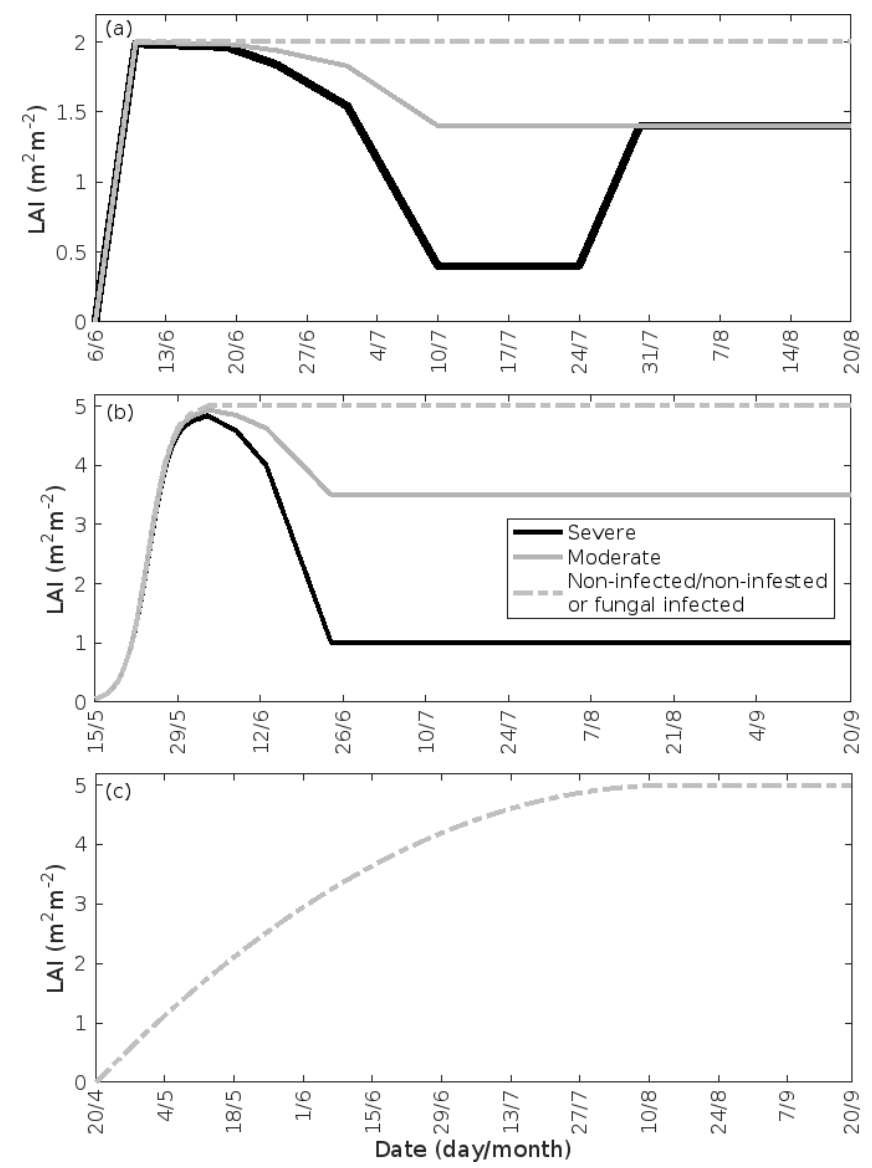

Figure 3. Leaf area index throughout the growing season in infected and non-infected forest stands: (a) mountain birch, (b) oak, and (c) poplar. A total of $30 \%$ (moderate infection scenario) or $80 \%$ (severe infection scenario) of the total leaf area in the forest stands is assumed to be consumed by the end of the feeding period in simulations of herbivory, while fungal infections do not decrease the leaf area. Note the different time axes.

ments of the whole plant. Instead, the emission rates from mountain birch seedlings (Yli-Pirilä et al., 2016) were upscaled in order to represent the emissions from mature trees, assuming a leaf mass area of $75 \mathrm{~g} \mathrm{~m}^{-2}$ for leaves growing on mature mountain birch trees (Riipi et al., 2005). Since emission response measurements are usually stopped, at a maximum, a few days after the herbivore activity has ceased, we assumed that the effect of stress on the emissions of VOC stops the day that the larvae pupate (e.g. Yli-Pirilä et al., 2016) in order to not overestimate the impact of the stress. The light- and temperature-dependent emission activity factors are computed using Eq. (2) in Guenther (1997), since none of the considered broadleaved species possess storage structures and birch has specifically been shown to only emit de novo (Ghirardo et al., 2010). Similarly to Guenther et al. (2012), we assumed that stress-induced emissions are controlled by light and temperature in the same way as constitutive emissions; thus, the used emission rates from the liter- 
ature were standardised according to Eq. (1). Copolovici et al. (2014) and Jiang et al. (2016) have also shown that the emissions of isoprene from oaks and poplars infected with oak powdery mildew and rust have the same response to light as control plants. Copolovici et al. (2014) additionally demonstrated that the emissions of monoterpenes from oak infected by oak powdery mildew depend strongly on light, even though the majority of emitted monoterpenes were not, e.g. ocimene and linalool, which are known to be light dependent (Niinemets et al., 2002; Arimura et al., 2008). LOX (lipoxygenase pathway volatile) compounds, on the other hand, are released shortly after damage of leaf tissue, independent of the light conditions (Arimura et al., 2008). LOX compounds do not contribute to the formation and growth processes of atmospheric aerosol particles, but they were included in the model in order to illustrate the changes in the atmospheric concentrations of LOX as a function of stress severity and stress type and for evaluating the reliability of our modelling results, since LOX in reality affect the atmospheric concentration of $\mathrm{OH}$, which was constrained in the model. The equations, which we used in the model for linking the emission factors to the severity of stress, are provided in Table 1 together with the parameters needed for the equations. The emission factors at a few different degrees of stress are written out in Table A1 in Appendix A. It was assumed that the emitted VOCs were instantaneously evenly distributed within the mixing volume, which is defined by the boundary layer height.

\subsection{Meteorological conditions}

The daily maximum radiation during the entire growing season was fixed to $1000 \mu \mathrm{mol} \mathrm{m}^{-2} \mathrm{~s}^{-1}$ (Table 2), which corresponds to the average maximum photosynthetic photon flux density (PPFD) observed at the SMEAR I station during the growing seasons of 2015-2017 (Aalto et al., 2019). The daily pattern of PPFD then follows the solar zenith angle. For simulations of mountain birch, we utilised the maximum and minimum mean temperatures on every day in the growing season during 2015-2017 observed at $9 \mathrm{~m}$ at the SMEAR I station (Aalto et al., 2019). The daily maximum and minimum temperatures ranged from 9.8 to $19.6^{\circ} \mathrm{C}$ and from 2.0 to $11.3{ }^{\circ} \mathrm{C}$, respectively, in the time period of interest (6 June-20 August, Fig. 4a). For simulations of oak and poplar, we utilised the maximum and minimum temperatures for southern Germany averaged over the past 3 decades (data obtained via https://www.currentresults.com/ Weather/Germany/average-annual-temperatures.php, last access: November 2021). This was done due to availability and restriction of data obtained at the Hohenpeißenberg Meteorological Observatory and since our aim was not as such to simulate the atmospheric impact at Hohenpeißenberg but instead at any relevant location, i.e. where oaks and poplars, including the biotic stresses of interests, are common. The monthly averaged daily maximum and minimum
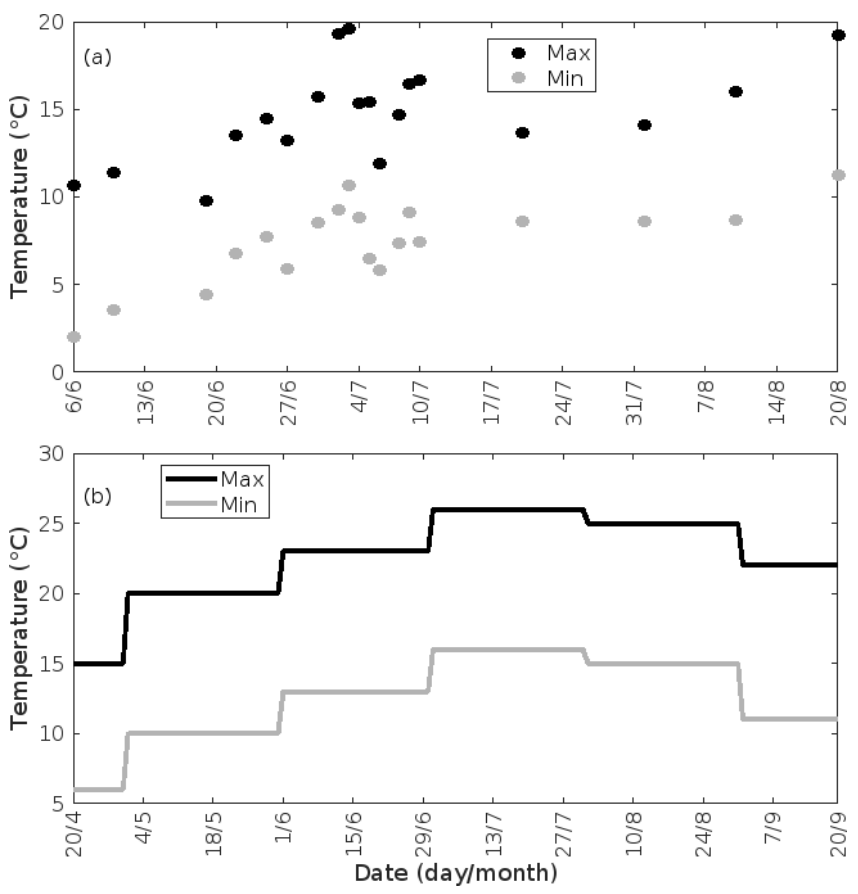

Figure 4. Daily maximum and minimum temperatures throughout the growing season at (a) SMEAR I, Lapland, and (b) southern Germany, used as default model input. Note the different time axes.

temperatures ranged from 15 to $26^{\circ} \mathrm{C}$, and from 6 to $16^{\circ} \mathrm{C}$, respectively, in the time period of interest (April-September, Fig. 4b). For simplicity, the daily temperature pattern followed that of the solar zenith angle with a forward shift of $1 \mathrm{~h}$. The default daytime mixing length was kept constant to a value of $700 \mathrm{~m}$ (simulations of mountain birch) and $2000 \mathrm{~m}$ (simulations of oak and poplar) above ground level (Seidel et al., 2012) (Table 2).

\subsection{Atmospheric gas-phase chemistry}

We prescribed the concentrations of atmospheric oxidants within the model, though in reality the concentration of atmospheric oxidants can decrease or increase depending on changes in the concentrations of individual specific VOCs (Table 3). This was done partly because it is difficult to accurately predict the concentration of oxidants (e.g. Di Carlo et al., 2004; Sinha et al., 2010; Mogensen et al., 2011, 2015; Nölscher et al., 2012, 2016; Zannoni et al., 2016; Praplan et al., 2019; Lelieveld et al., 2008; Taraborrelli et al., 2012) and partly because accounting for varying oxidant concentrations is not necessary for the objectives of our study (Sect. 3.2, Fig. 11a-b, f-g, k-1, p-q). Thus, in our simulations the default daily maximum concentration of $\mathrm{OH}$ is therefore fixed to $6 \times 10^{6}$ molec. $\mathrm{cm}^{-3}$ (Petäjä et al., 2009) and $8 \times 10^{5}$ molec. $\mathrm{cm}^{-3}$ (calculated using observed summertime UVB radiation from the SMEAR I station and the proxy presented by Petäjä et al., 2009) for simulations of Hohen- 
Table 1. Equations to calculate the emission factors $\left(\varepsilon_{i, E E}\right.$, in $\mathrm{nmol} \mathrm{m}^{-2}$ one-sided LAI s $\left.{ }^{-1}\right)$, as a function of the degree of stress $(A E)$, together with the parameters needed for the equations. The equations are valid for infection levels ranging from $0 \%$ to $80 \%$ unless otherwise stated. The emission factors for oak and poplar are presented without the downscaling by a factor of 0.57 (see Sect. 2.4). LMA $_{\mathrm{f}}$ is the fraction of the leaf mass area of leaves growing on mature mountain birch divided by leaves growing on mountain birch seedlings, which is included so that the emission factors for mountain birches are also representative of mature trees. ISO stands for isoprene, MT stands for monoterpenes, MeSa stands for methyl salicylate, LOX stands for lipoxygenase pathway volatile compounds, DMNT stands for 4,8-dimethyl-1,3,7-nonatriene, $\mathrm{MeOH}$ stands for methanol, SQT stands for sesquiterpenes, and $\alpha$-Eud stands for $\alpha$-Eudesmol.

\begin{tabular}{|c|c|c|c|c|c|c|}
\hline VOC & $\varepsilon_{i, E}\left(\mathrm{nmol} \mathrm{m}^{-2} \mathrm{~s}^{-1}\right)$ & $\varepsilon_{i, 0}\left(\mathrm{nmol} \mathrm{m}^{-2} \mathrm{~s}^{-1}\right)$ & $A\left(\mathrm{nmol} \mathrm{m}^{-2} \mathrm{~s}^{-1}\right)$ & $B$ & $C\left(\mathrm{nmol} \mathrm{m}^{-2} \mathrm{~s}^{-1}\right)$ & \\
\hline ISO & $\begin{array}{l}\varepsilon_{i, 0}+\frac{E \times A}{B+E}, 0 \leq E \leq 60 \\
\varepsilon_{i, 60} \times 0.5,60<E \leq 80\end{array}$ & 30.26 & -47.40 & 34.48 & & \\
\hline MT & $\varepsilon_{i, 0}+\frac{E \times A}{B+E}$ & $4.0 \times 10^{-2}$ & 9.22 & 33.42 & & \\
\hline MeSa & $A E \times A$ & & $3.5 \times 10^{-3}$ & & & \\
\hline LOX & $A \times E^{2}+C \times A$ & & $1.1 \times 10^{-3}$ & & $4.7 \times 10^{-2}$ & \\
\hline DMNT & $A \times E^{2}+C \times A$ & & $1.0 \times 10^{-5}$ & & $1.3 \times 10^{-3}$ & \\
\hline \multicolumn{7}{|c|}{ Infection of pedunculate oak (Quercus robur) by oak powdery mildew (Erysiphe alphitoides) based on Copolovici et al. (2014) } \\
\hline VOC & $\varepsilon_{i, E}\left(\mathrm{nmol} \mathrm{m}^{-2} \mathrm{~s}^{-1}\right)$ & $\varepsilon_{i, 0}\left(\mathrm{nmol} \mathrm{m}^{-2} \mathrm{~s}^{-1}\right)$ & $A\left(\mathrm{nmol} \mathrm{m}^{-2} \mathrm{~s}^{-1}\right)$ & $B\left(\mathrm{nmol} \mathrm{m}^{-2} \mathrm{~s}^{-1}\right)$ & $C\left(\mathrm{nmol} \mathrm{m}^{-2} \mathrm{~s}^{-1}\right)$ & \\
\hline ISO & $\varepsilon_{i, 0}+A \times E+B \times E^{2}+C \times E^{3}$ & 10.6 & -0.244 & $3.69 \times 10^{-3}$ & $-2.05 \times 10^{-5}$ & \\
\hline MT & $\varepsilon_{i, 0}+A \times E+B \times E^{2}+C \times E^{3}$ & $4.0 \times 10^{-2}$ & $8.7 \times 10^{-3}$ & $-7.1 \times 10^{-5}$ & $3.7 \times 10^{-7}$ & \\
\hline $\mathrm{MeSa}$ & $\begin{array}{l}0, \nexists E=0 \\
A \times \frac{\varepsilon_{M T, A}}{\varepsilon_{M T, 60}}, 0<A \leq 80\end{array}$ & & 0.437 & & & \\
\hline LOX & $A+B \times E$ & & $2.13 \times 10^{-3}$ & $6.24 \times 10^{-3}$ & & \\
\hline \multicolumn{7}{|c|}{ Infection of balsam poplar (Populus balsamifera var. suaveolens) by poplar rust (Melampsora larici-populina) based on Jiang et al. (2016) } \\
\hline VOC & $\varepsilon_{i, E}\left(\mathrm{nmol} \mathrm{m}^{-2} \mathrm{~s}^{-1}\right)$ & $\varepsilon_{i, 0}\left(\mathrm{nmol} \mathrm{m}^{-2} \mathrm{~s}^{-1}\right)$ & $A\left(\mathrm{nmol} \mathrm{m}^{-2} \mathrm{~s}^{-1}\right)$ & $B\left(\mathrm{nmol} \mathrm{m}^{-2} \mathrm{~s}^{-1}\right)$ & $C$ & $E\left(\mathrm{nmol} \mathrm{m}^{-2} \mathrm{~s}^{-1}\right)$ \\
\hline ISO & $A+\frac{B}{C+A}$ & & 12.3 & 366.8 & 4.98 & \\
\hline MT & $\begin{array}{l}0.0625, A E=0 \\
A+B \times A+E \times E^{2}, 0<A \leq 80\end{array}$ & & 0.112 & $1.84 \times 10^{-3}$ & & $1.5 \times 10^{-4}$ \\
\hline $\mathrm{MeSa}$ & $A \times A E+B \times E^{2}+E \times E^{3}$ & & $6.32 \times 10^{-3}$ & $-8.6 \times 10^{-5}$ & & $5.75 \times 10^{-7}$ \\
\hline LOX & $\begin{array}{l}0.4814, E=0 \\
\left(A+B \times A+E \times E^{2}\right) \times C, 0<A \leq 80\end{array}$ & & 2.51 & $-2.51 \times 10^{-2}$ & $\begin{array}{r}0.76,0<E<30 \\
0.85,30 \leq E<60 \\
0.93,60 \leq E \leq 80\end{array}$ & $3.25 \times 10^{-3}$ \\
\hline DMNT & $\begin{array}{l}\varepsilon_{\mathrm{DMNT}, 60} \times \frac{\varepsilon_{\mathrm{MeSa},}}{\varepsilon_{\mathrm{MeSa}, 60}}, 0 \leq A E<60 \\
\varepsilon_{\mathrm{MeSa}, E} \times C, 60 \leq A \leq \leq 0\end{array}$ & & & & 0.36 & \\
\hline $\mathrm{MeOH}$ & $\varepsilon_{i, 0}+A \times A+B \times A^{2}$ & 16.9 & -0.338 & $1.36 \times 10^{-2}$ & & \\
\hline SQT & $\begin{array}{l}\varepsilon_{\mathrm{SQT}, 60} \times \frac{\varepsilon_{\mathrm{MeSa}, E}}{\varepsilon_{\mathrm{MSa}, 60}}, 0 \leq E<60 \\
\varepsilon_{\mathrm{MeSa}, E} \times C, 60 \leq E \leq 80\end{array}$ & & & & 2.414 & \\
\hline$\alpha$-Eud & $\begin{array}{l}\varepsilon_{\alpha \text {-Eud, } 60} \times \frac{\varepsilon_{\mathrm{MeSa}, E}}{\varepsilon_{\mathrm{MeS}, 60}}, 0 \leq E<60 \\
\varepsilon_{\mathrm{MeSa}, E} \times C, 60 \leq A E \leq 80\end{array}$ & & & & 0.397 & \\
\hline \multicolumn{7}{|c|}{ Infestation of mountain birch (Betula pubescens var. pumila) by autumnal moth (Epirrita autumnata) based on Yli-Pirilä et al. (2016) } \\
\hline VOC & $\varepsilon_{i, E}\left(\mathrm{nmol} \mathrm{m}^{-2} \mathrm{~s}^{-1}\right)$ & $A$ & $B$ & $C$ & $E\left(\mathrm{nmol} \mathrm{m}^{-2} \mathrm{~s}^{-1}\right)$ & $\mathrm{LMA}_{\mathrm{f}}$ \\
\hline MT & $\left(A+\frac{E \times B}{\sqrt{1+\frac{B^{2} \times E^{2}}{C^{2}}}}\right) \times E \times \mathrm{LMA}_{\mathrm{f}}$ & $7.65 \times 10^{-2}$ & $9.33 \times 10^{-3}$ & 0.2146 & 0.769 & 2.23 \\
\hline LOX & $(A \times A+B) \times E \times \mathrm{LMA}_{\mathrm{f}}$ & $6.325 \times 10^{-3}$ & $4.868 \times 10^{-2}$ & & 0.8 & 2.23 \\
\hline DMNT & $\left(A+\frac{E \times B}{\sqrt{1+\frac{B^{2} \times A^{2}}{C^{2}}}}\right) \times E \times \mathrm{LMA}_{\mathrm{f}}$ & $7.11 \times 10^{-4}$ & $3.39 \times 10^{-4}$ & $8.63 \times 10^{-3}$ & 0.769 & 2.23 \\
\hline SQT & $\frac{\varepsilon_{\mathrm{MT}, E}}{3}$ & & & & & \\
\hline
\end{tabular}


Table 2. Model inputs. Representative summertime conditions in rural central Europe (here indicated by HPB, i.e. the Hohenpeißenberg Meteorological Observatory) and Lapland (here indicated by the SMEAR I station) are used as default model input. The conditions are chosen such that they are realistic and representative, but they do not inhibit the formation of new particles. The concentrations of $\mathrm{OH}$ and sulfuric acid are provided as daily maxima in the table, but their concentrations decrease as a function of the decrease in solar light in the simulations. The concentration of ozone and the condensation sink (CS) are both kept constant throughout the simulations. BLH is the planetary boundary layer height. The photosynthetic photon flux density (PPFD) is provided as the daily maximum in the table, but the daily pattern of PPFD follows the solar zenith angle in the model.

\begin{tabular}{lrr}
\hline & HPB & SMEAR I \\
\hline$\left[\mathrm{O}_{3}\right](\mathrm{ppb})$ & 45 & 30 \\
{$[\mathrm{OH}]_{\max }\left(\right.$ molec. $\left.\mathrm{cm}^{-3}\right)$} & $6 \times 10^{6}$ & $8 \times 10^{5}$ \\
{$\left[\mathrm{H}_{2} \mathrm{SO}_{4}\right]_{\max }\left(\right.$ molec. $\left.\mathrm{cm}^{-3}\right)$} & $1 \times 10^{7}$ & $2.5 \times 10^{6}$ \\
$\mathrm{CS}\left(\mathrm{s}^{-1}\right)$ & $2.5 \times 10^{-3}$ & $7 \times 10^{-4}$ \\
$\mathrm{BLH}(\mathrm{m})$ & 2000 & 700 \\
$\mathrm{PPFD}_{\max }\left(\mu \mathrm{mol} \mathrm{m}^{-2} \mathrm{~s}^{-1}\right)$ & 1000 & 1000 \\
\hline
\end{tabular}

peißenberg and Lapland, respectively (Table 2). The daily pattern of the $\mathrm{OH}$ concentration then follows the solar zenith angle. The concentration of ozone is kept constant to a value of $45 \mathrm{ppb}$ (Naja et al., 2003) and $30 \mathrm{ppb}$ (Ruuskanen et al., 2003) for simulations of oak and poplar (Hohenpeißenberg conditions) and mountain birch (SMEAR I conditions), respectively (Table 2). $\mathrm{NO}_{3}$ was not considered, since emission and atmospheric processes were only simulated during daytime, when the concentration of $\mathrm{NO}_{3}$ is insignificant.

The only source of sulfuric acid $\left(\mathrm{H}_{2} \mathrm{SO}_{4}\right)$ in our model is the reaction between $\mathrm{OH}$ and $\mathrm{SO}_{2}$, while the only sink is the condensation sink. The concentration of $\mathrm{SO}_{2}$ is chosen such that the default daytime maximum concentration of $\mathrm{H}_{2} \mathrm{SO}_{4}$ is $1 \times 10^{7}$ molec. $\mathrm{cm}^{-3}$ in Hohenpeißenberg (Petäjä et al., 2009; Birmili et al., 2003) and $2.5 \times 10^{6}$ molec. $\mathrm{cm}^{-3}$ in Lapland (Kyrö et al., 2014) (Table 2). The size distribution of the pre-existing particle population is kept fixed during the simulations, and thus the number concentration of preexisting particles is defined by the condensation sink (CS), which is kept constant to a value of $2.5 \times 10^{-3} \mathrm{~s}^{-1}$ (in rural southern Germany) and $7 \times 10^{-4} \mathrm{~s}^{-1}$ (in Lapland; Dal Maso et al., 2007; Vana et al., 2016) (Table 2).

We included reactions for the atmospheric oxidation of $\mathrm{SO}_{2}$ and the emitted VOCs (Appendix C). Certain VOCs, especially VOCs with endocyclic double bonds, can form HOM (highly oxygenated organic molecules) upon oxidation by $\mathrm{O}_{3}$ in particular but also by $\mathrm{OH}$ and $\mathrm{NO}_{3}$ (e.g. Ehn et al., 2012, 2014; Jokinen et al., 2015; Berndt et al., 2016; Bianchi et al., 2019; Zhao et al., 2021). HOM have been found to be a major component of secondary organic aerosol (e.g. Ehn et al., 2014; Mutzel et al., 2015). HOM yields are specific to individual molecules and isomers and most yields have not been investigated for the exact compounds, which are emitted from the tree species considered in this study. Thus, the yields applied for the production of HOM in the model (Appendix C) are connected with a large degree of uncertainty. The influence of changing HOM yields on our results was therefore also investigated (Sect. 3.2, Fig. 11e, $\mathrm{j}, \mathrm{o}, \mathrm{t}$ ). Formation of oxygenated organics from oxidation of sesquiterpenes and methyl salicylate are also included (Appendix C). The sum of all organic compounds, which contribute to aerosol processes, is referred to as "OxOrg". The chemistry was solved by the ordinary differential equation solver DLSODE (Radhakrishnan and Hindmarsh, 1993), and it was assumed that the concentrations of all considered atmospheric molecules were homogeneously distributed within the mixing volume.

\subsection{Calculation of the formation and growth of secondary organic aerosol particles}

The clustering and activation of new particles are expressed by a formation rate of neutral $2 \mathrm{~nm}$ clusters, $J_{2}\left(\mathrm{~cm}^{-3} \mathrm{~s}^{-1}\right)$, which is computed by Eq. (20) using coefficients $\left(\alpha_{1-3}\right)$ from Table 3, both found in Paasonen et al. (2010):

$$
\begin{aligned}
J_{2} & =\alpha_{1} \times\left[\mathrm{H}_{2} \mathrm{SO}_{4}\right]^{2}+\alpha_{2} \times\left[\mathrm{H}_{2} \mathrm{SO}_{4}\right][\mathrm{OxOrg}] \\
& +\alpha_{3} \times[\mathrm{OxOrg}]^{2} .
\end{aligned}
$$

It is here assumed that new particles are formed via heteromolecular homogeneous nucleation between sulfuric acid and oxidised organic compounds (OxOrg) and via homogeneous nucleation of sulfuric acid and OxOrg alone. For simplification, we only operated with one growing aerosol mode and therefore included a unit-less correction term (KK) that determines how large a fraction of the activated clusters reaches the growing mode (Kerminen and Kulmala, 2002):

$\mathrm{KK}=\exp \left(\eta \times\left[1 / D_{\mathrm{p}}-1 / D_{\text {clus }}\right]\right)$,

where $D_{\mathrm{p}}$ and $D_{\text {clus }}$ are the diameters of the growing mode and clusters, respectively, and $D_{\text {clus }}=2 \mathrm{~nm}$ as stated above. Further, $\eta(\mathrm{nm})$ is (Eqs. 11-12 and Table 1 in Kerminen and Kulmala, 2002) calculated as follows:

$\eta=1830 \mathrm{~nm}^{2} \mathrm{sh}^{-1} \times \mathrm{CS} / \mathrm{GR}$,

where CS $\left(\mathrm{s}^{-1}\right)$ is the condensation sink. When used together with Eq. (3), the value of CS is that of sulfuric acid. The condensational particle diameter growth rate $\left(\mathrm{GR}, \mathrm{nm} \mathrm{h}^{-1}\right)$ of newly formed $2-3 \mathrm{~nm}$ particles is calculated according to Nieminen et al. (2010):

$\mathrm{GR}_{2-3 \mathrm{~nm}}=0.5 \mathrm{~nm} \mathrm{~h}^{-1} \times \mathrm{CC} \times 10^{-7} \mathrm{~cm}^{3}$,

where $\mathrm{CC}$ is the concentration of condensable vapours, which we assumed to be the sum of sulfuric acid and OxOrg. In addition, we assumed that the molar mass of OxOrg 
Table 3. Common changes in the atmospheric concentrations of volatile organic compounds (VOC) and OH during biotic plant stress. LOX are lipoxygenase pathway volatile compounds.

\begin{tabular}{|c|c|c|c|}
\hline & $\begin{array}{l}\text { Change in VOC } \\
\text { concentration }\end{array}$ & Change in $\mathrm{OH}$ concentration & Reference \\
\hline \multirow[t]{3}{*}{ Stress $\uparrow$} & $\begin{array}{l}{[\mathrm{LOX}] \uparrow} \\
{[\text { methyl salicylate }] \uparrow} \\
{[\text { methanol }] \uparrow} \\
{[\text { monoterpenes }] \uparrow}\end{array}$ & {$[\mathrm{OH}] \downarrow$} & $\begin{array}{l}\text { Mentel et al. (2013) } \\
\text { Calvert et al. (2000) } \\
\text { Atkinson et al. (1992) } \\
\text { Hakola et al. (1994) }\end{array}$ \\
\hline & [sesquiterpenes] $\uparrow$ & {$[\mathrm{OH}] \uparrow$} & $\begin{array}{l}\text { Atkinson and Arey (2003) } \\
\text { Winterhalter et al. (2009) }\end{array}$ \\
\hline & [isoprene $] \downarrow$ & {$[\mathrm{OH}]$ ? but most probably $[\mathrm{OH}] \uparrow$} & $\begin{array}{l}\text { Lelieveld et al. (2008) } \\
\text { Taraborrelli et al. (2012) } \\
\text { Wells et al. (2020) }\end{array}$ \\
\hline
\end{tabular}

is 3.5 times larger than that of sulfuric acid (Ehn et al., 2014):

$\mathrm{CC}=\left[\mathrm{H}_{2} \mathrm{SO}_{4}\right]+[\mathrm{OxOrg}] \times 3.5^{1 / 3}$.

It is a complex matter to model nanoparticle growth, especially in forested environments, since thousands of individual molecules with different vapour pressures contribute to the growth, but particle growth rates have been observed to be strongly size dependent in the field (Hirsikko et al., 2005; Yli-Juuti et al., 2011; Häkkinen et al., 2013). Hence, we accounted for this size dependency by enhancing the growth rates of particles larger than $3 \mathrm{~nm}$, following Hirsikko et al. (2005) and Yli-Juuti et al. (2011):

$$
\begin{aligned}
& \mathrm{GR}_{3-7 \mathrm{~nm}}=2 \times \mathrm{GR}_{2-3 \mathrm{~nm}} \\
& \mathrm{GR}_{>7 \mathrm{~nm}}=2.3 \times \mathrm{GR}_{2-3 \mathrm{~nm}} .
\end{aligned}
$$

The increase in the diameter of the growing mode $\left(D_{\mathrm{p}}\right)$ is defined by the growth rate:

$$
\Delta D_{\mathrm{p}} / \Delta t=\mathrm{GR} / 3600 \mathrm{sh}^{-1}
$$

while the increase in the number of new particles $\left(N_{\mathrm{p}}, \mathrm{cm}^{-3}\right)$ is determined by the formation of new particles that reaches the growing mode and the coagulation of particles in the growing mode by

$\Delta N_{\mathrm{p}} / \Delta t=J_{2} \times \mathrm{KK}-\mathrm{CoagS} \times N_{\mathrm{p}}$,

where the coagulation sink (CoagS, $\left.\mathrm{s}^{-1}\right)$ is calculated according to Lehtinen et al. (2007):

$\operatorname{CoagS}=\mathrm{CS} \times\left(0.71 \mathrm{~nm} / D_{\mathrm{p}}\right)^{1.6}$.

\section{Results and discussion}

\subsection{Simulations of biotically stressed and non-infected forest stands throughout a growing season}

Simulation results of one full growing season from various non-infected and moderately and severely infected for- est stands are presented in Figs. 5-9. In the figures, emissions, concentrations, the isoprene-to-monoterpenes carbon concentration ratio $(R=$ [isoprene $\mathrm{C}] /[$ monoterpenes $\mathrm{C}]=0.5 \times[$ isoprene $] /[$ monoterpenes $])$, the formation and growth rates, and number of newly formed particles are expressed as median values during 10:00-16:00 LT, while the particle diameter of the growing mode is provided as the daily maximum. We underline that our modelling study is of a conceptual character and that the modelling results therefore also should be treated accordingly. Modelling results are compared in detail to observations in the sections below in order to put our findings into perspective.

\subsubsection{Canopy emissions of VOCs}

The emissions of VOCs (Figs. 5a, c, e, g, 7a, b, 8a, b, 9a-c) change throughout the season due to variations in temperature, light, LAI, and infection severity. The impact of leaf maturity development on emission predictions are presented in Appendix B, and its atmospheric relevance is discussed in Sect. 3.2. Canopy emissions of VOCs are highly different from non-infected and infected forest stands due to plant stress responses and also due to a decrease in LAI in case of larval infestations (Figs. 5a, c, e, g, 9a-c). Constitutive isoprene emitters (i.e. oak and poplar) decrease their emissions of isoprene significantly during the episodes of biotic stress, and a stronger reduction is observed as a function of an increase in stress severity (Figs. 5a, 7a, 8a). All investigated stresses cause the plants to increase their emissions of monoterpenes greatly (Figs. $5 c, 7 b, 8 b, 9 a)$. The induction in the emissions of monoterpenes increases as a function of stress severity per unit leaf area, but the LAI simultaneously decreases in case of larval infestations, which result in smaller canopy-scale emissions from severely defoliated stands compared to moderately stressed stands (Figs. 5c, 9a). In addition, the emissions of compounds and groups of compounds, such as methyl salicylate, LOX, methanol, DMNT, sesquiterpenes, and oxygenated sesquiterpenes, are signifi- 
cantly increased as a result of biotic plant stress (Figs. 5e, g, $7 \mathrm{a}, \mathrm{b}, 8 \mathrm{a}, \mathrm{b}, 9 \mathrm{~b}, \mathrm{c})$. These compounds, together with monoterpenes, are in most cases not emitted constitutively at all or only in very small abundances from the considered tree species. Though the emissions of all induced VOCs increase as a function of the degree of damage, the responses to the level of stress severity are not necessarily the same for all VOCs and all individual stresses. This difference can, for example, be seen in the emissions of monoterpenes (Fig. 5c) and LOX compounds (Fig. 5e) from oak forests infested by gypsy moth, which do not peak at the same time in the season.

\subsubsection{Ambient concentrations of VOCs and OxOrg}

Since the concentrations of $\mathrm{OH}$ and $\mathrm{O}_{3}$ are constrained within the simulations, the VOC emission patterns are reflected in the concentration patterns (Figs. 5b, d, f, h, 7ce, $8 \mathrm{c}-\mathrm{e}, 9 \mathrm{e}-\mathrm{g})$. All VOCs, except LOX and methanol, contribute to the formation of OxOrg (Figs. 6a, 7c, 8c, 9d), but the contributions from oxidation of the individual VOCs or groups of VOCs vary between the various stress cases and infection severity levels due to differences in emission rates and OxOrg-forming yields (Appendix C). For example, in herbivory-infested stands, OxOrg originating from monoterpenes make up by far the largest fraction of total OxOrg. This is mainly due to the fact that the induced emissions of monoterpenes are significantly higher than the emissions of other VOCs that contribute to OxOrg formation (Figs. 5c, g, 9a, c). In the case of oak infected by oak powdery mildew, HOM from monoterpenes and oxygenated organics from methyl salicylate reactions contribute about evenly to the total OxOrg. The reason for this is that the canopy emissions of these VOCs are roughly similar (Fig. 7a, b), the OxOrg yield of methyl salicylate is significantly higher than that of monoterpenes, but oxidation of methyl salicylate is correspondingly slower (Appendix C). The main contributor to the total OxOrg in poplar stands infected by poplar rust is sesquiterpenes. Contributions from methyl salicylate, DMNT, and $\alpha$-Eudesmol to total OxOrg are individually rather small, but together they are close to matching the contribution from monoterpenes. When emissions of sesquiterpenes are omitted from simulations of a severely rust-infected poplar stand, the concentration of OxOrg decreases with $\sim 46 \%$, while in comparison the concentration of OxOrg decreases with $\sim 30 \%$ if the emissions of monoterpenes are instead excluded.

In the simulations, the daily median (10:00-16:00 LT) ambient concentration of OxOrg is at maximum $\sim 4.2 \times$ $10^{7} \mathrm{~cm}^{-3}$ in an oak stand infested by gypsy moth (Fig. 6a), $\sim 1.1 \times 10^{7} \mathrm{~cm}^{-3}$ in an oak stand infected by oak powdery mildew (Fig. $7 \mathrm{c}$ ), $\sim 4.2 \times 10^{7} \mathrm{~cm}^{-3}$ in a poplar stand infected by rust (Fig. $8 \mathrm{c}$ ), and $\sim 3.3 \times 10^{7} \mathrm{~cm}^{-3}$ in a mountain birch stand infested by autumnal moth (Fig. 9d). The ambient concentration of OxOrg is much higher in oak stands infested by gypsy moth than in a non-infested oak stand during the period of stress (Fig. 6a). When the period of feeding has been concluded, the concentration of OxOrg is higher in noninfested oak stands than in stands that have been exposed to stress due to a higher LAI. However, the concentration of OxOrg is then only $\sim 15 \%-20 \%$ of the OxOrg concentration during the period of stress, and it is almost exclusively composed of HOM originating from isoprene. The concentration of OxOrg increases as a function of fungal infection severity, and in our simulations the concentration of OxOrg is higher in fungally infected stands by a factor of up to $\sim 6.9$ (oak stands infected by oak powdery mildew, Fig. 7c) and $\sim 3.3$ (poplar stands infected by poplar rust, Fig. 8c). Since the investigated poplar species is a great constitutive isoprene emitter, relatively high concentrations of OxOrg are predicted for the non-infected poplar stand (Fig. 8c). In mountain birch stands, the concentration of OxOrg is up to 2-2.5 times higher in stands infested by autumnal moth during the feeding period than in a non-infested birch stand (Fig. 9d). The difference in OxOrg concentration between moderately and severely infested birch stands is small due to the combined effects of stress response (which is a function of the degree of damage) and LAI reduction (Fig. 9d), but towards the conclusion of the feeding period the concentration of OxOrg is significantly higher in the less defoliated stand.

\subsubsection{Formation of new particles}

New particles are assumed to be formed from OxOrg and sulfuric acid (Sect. 2.7, Eq. 2). Since the concentration of sulfuric acid is constrained within the simulations, the concentration pattern of OxOrg is reflected in the seasonal pattern of the formation rates (Figs. 6c-e, 7f, 8f, 9h, i). Thus, in case of oak infested by gypsy moth, the formation rates are much higher (increase by up to a factor of $\sim 5\left(J_{2}\right), \sim 7$ $\left(J_{3}\right)$, and $\left.\sim 11\left(J_{10}\right)\right)$ in stressed stands than in non-infested stands during the period when the plants are exposed to stress (Fig. 6c-e). The predicted $J_{2}$ in oak stands infested by gypsy moth is comparable to, e.g. observations from Melpitz, Germany ( $\sim 9.4 \mathrm{~cm}^{-3} \mathrm{~s}^{-1}$, Paasonen et al., 2010), and San Pietro Capofiume, Italy ( $\sim 13 \mathrm{~cm}^{-3} \mathrm{~s}^{-1}$, Paasonen et al., 2010). Both Melpitz and San Pietro Capofiume are rural sites influenced by anthropogenic pollution (Paasonen et al., 2010). The modelled $J_{2}$ in a non-infested oak stand is comparable to observations from Hohenpeißenberg $\left(\sim 2.3 \mathrm{~cm}^{-3} \mathrm{~s}^{-1}\right.$, Paasonen et al., 2010) and similar or even higher than typical formation rates measured in the boreal Scots pine forest in Hyytiälä, Finland $\left(\sim 1-2 \mathrm{~cm}^{-3} \mathrm{~s}^{-1}\right.$, Paasonen et al., 2010; Kulmala et al., 2012, 2013; Vana et al., 2016), and in the hemiboreal forest in Järvseljä, Estonia $(\sim 1.09 \pm$ $1.06 \mathrm{~cm}^{-3} \mathrm{~s}^{-1}$, Vana et al., 2016). By analysing data from Hyytiälä and Järvseljä, Vana et al. (2016) showed that the values of $J_{3}$ were in general about $60 \%-80 \%$ of those of $J_{2}$. Our simulations of a non-infested oak stand follow this threshold; thus, the predicted $J_{3}$ in a non-infested oak 
stand is somewhat higher than observations from Hyytiälä $\left(\sim 0.6 \mathrm{~cm}^{-3} \mathrm{~s}^{-1}\right.$, Kulmala et al., 2012, 2013; Nieminen et al., 2014; Vana et al., 2016) and Järvseljä $\left(\sim 0.8 \mathrm{~cm}^{-3} \mathrm{~s}^{-1}\right.$, Vana et al., 2016). $J_{3}$ in oak stands infested by gypsy moth is high, but similar values have occasionally been observed in Hyytiälä (up to about $10 \mathrm{~cm}^{-3} \mathrm{~s}^{-1}$, Nieminen et al., 2014). Formation rates of $5 \mathrm{~nm}$ particles $\left(J_{5}=1.0 \pm 1.1 \mathrm{~cm}^{-3} \mathrm{~s}^{-1}\right.$, Yu et al., 2014) measured in an oak forest in Missouri, USA, are much less than $J_{10}$ in our simulated infested stands as are, e.g. formation rates of $10 \mathrm{~nm}$ particles $\left(J_{10}=1.2 \mathrm{~cm}^{-3} \mathrm{~s}^{-1}\right.$, Yli-Juuti et al., 2009) measured in a mixed forest in K-puszta in rural Hungary. Thus, the predicted formation rates in a non-infested oak stand are comparable, and in the case of gypsy moth infested oak stands, often much higher than observations from forests with intense new particle formation events.

The formation rates of new particles are always higher in oak powdery mildew infected oak stands than in a noninfected oak stand (Fig. 7f), though the fungus is not able to perturb the formation rates as strongly (increase by up to a factor of $\sim 2.3\left(J_{2}\right), \sim 3.0\left(J_{3}\right)$, and $\left.\sim 5.3\left(J_{10}\right)\right)$ as herbivory by gypsy moth larvae.

Simulations of poplar stands suggest that particles will be formed at high rates in the range $\sim 3.6-11.4 \mathrm{~cm}^{-3} \mathrm{~s}^{-1}\left(J_{2}\right)$ and $\sim 2.7-10.6 \mathrm{~cm}^{-3} \mathrm{~s}^{-1}\left(J_{3}\right)$ during the late summer when the full leaf state has been attained, and our simulations suggest that new particles will be formed the fastest in severely rust-infected stands (increase of up to a factor of $\sim 3.2\left(J_{2}\right)$, and $\left.\sim 3.9\left(J_{3}\right)\right)$.

In our simulations, herbivory by autumnal moth increases the formation rates of new particles in mountain birch stands by up to a factor of $\sim 2.5\left(J_{2}\right)$ and $\sim 2.6\left(J_{3}\right)$. The formation rates of 2 and $3 \mathrm{~nm}$ particles are predicted to vary between 0.38 and $2.5 \mathrm{~cm}^{-3} \mathrm{~s}^{-1}\left(J_{2}\right)$, and 0.31 and $2.5 \mathrm{~cm}^{-3} \mathrm{~s}^{-1}$ $\left(J_{3}\right)$ in stressed stands, and between 0.32 and $1.1 \mathrm{~cm}^{-3} \mathrm{~s}^{-1}$ $\left(J_{2}\right)$, and 0.26 and $0.99 \mathrm{~cm}^{-3} \mathrm{~s}^{-1}\left(J_{3}\right)$ in non-infested stands. The higher end of these values is comparable to rates observed in Hohenpeißenberg and Hyytiälä (see above). Kyrö et al. (2014) reported that the monthly averaged formation rate of $3 \mathrm{~nm}$ particles during 2005-2011, at the SMEAR I station in Värriö, varied throughout the year by $0.04-0.45$ and by $0.16-0.23 \mathrm{~cm}^{-3} \mathrm{~s}^{-1}$ during the summer months. Analysis of years 2013 and 2014, also at Värriö, led to a median formation rate of $0.14 \pm 0.05 \mathrm{~cm}^{-3} \mathrm{~s}^{-1}\left(J_{3}\right)$ (Vana et al., 2016). Thus, the predicted formation rates especially in non-infested mountain birch stands in Lapland are generally within range, but often somewhat higher than observations from the same location. It should, however, be mentioned that these literature values cannot be used to validate our simulation results, since Scots pines and not mountain birches dominate the SMEAR I site (Kyrö et al., 2014), and the LAI of mountain birches at the station is significantly lower than $2 \mathrm{~m}^{2} \mathrm{~m}^{-2}$ (Ylivinkka et al., 2020). The modelled formation rates are not compared to observations from the areas dominated by mountain birch in Lapland, since such observations do not, to our knowledge, exist.

A very recent investigation of long-term field observations (25 years) from the SMEAR I station (Ylivinkka et al., 2020), where autumnal moth larvae are prominent defoliators of mountain birches, did, however, not find any evidence that herbivory by autumnal moth would enhance the formation or growth of atmospheric aerosol particles during the summer of infestation. Instead there was some evidence of elevated total particle concentrations for a few years after summers with larval infestation, which was speculated to be caused by delayed defence responses of mountain birches. It is, however, possible that the total foliage mass of mountain birches in the area is too small or that the level of infestation was too low during the investigated time period, in order to cause detectable changes in aerosol variables (Ylivinkka et al., 2020).

The amount of newly formed particles is predicted to be up to about an order of magnitude higher in an oak stand infested by gypsy moth than in a non-infested oak stand, with a 10:00-16:00 LT median of up to $\sim 1.4 \times 10^{5} \mathrm{~cm}^{-3}$ in an infested stand (Fig. 6f). Such a high production of new particles is comparable to observations from, e.g. Melpitz (Größ et al., 2018). The number of produced particles in a non-infested oak stand $\left(\sim 1.1 \times 10^{4} \mathrm{~cm}^{-3}\right.$; Fig. $\left.6 \mathrm{f}\right)$ is comparable to, e.g. the number of new particles produced during a typical new particle formation event in Hyytiälä $\left(\sim 1-2 \times 10^{4} \mathrm{~cm}^{-3}\right.$; Dal Maso et al., 2008; Nieminen et al., 2014) but significantly higher than observations from a Missouri oak forest, where sub-5 $\mathrm{nm}$ particles were measured to be up to $\sim 2 \times 10^{4} \mathrm{~cm}^{-3}$ and 5-25 nm particles up to $\sim 3000 \mathrm{~cm}^{-3}$ during typical new particle formation events (Yu et al., 2014). After the period of stress, the number of particles in the growing mode is predicted to range between $\sim 7 \times 10^{3}$ and $\sim 17 \times 10^{3} \mathrm{~cm}^{-3}$ in a non-infested stand, $\sim 6 \times 10^{3}$ and $\sim 12 \times 10^{3} \mathrm{~cm}^{-3}$ in a $30 \%$ defoliated stand, and between $\sim 3 \times 10^{3} \mathrm{~cm}^{-3}$ and $\sim 5 \times 10^{3} \mathrm{~cm}^{-3}$ in a $80 \%$ defoliated oak stand (Fig. 6f). Oak powdery mildew is predicted to enhance the number of particles in the growing mode by up to a factor of $\sim 4$ compared to the corresponding non-infected stand, resulting in a maximum of $\sim 1.7 \times 10^{4} \mathrm{~cm}^{-3}$ in an infected stand under the used border conditions (Fig. 7g). Under the same environmental conditions, a poplar stand severely infected by poplar rust is predicted to produce up to about 5 times as many new particles as a non-infected poplar stand, leading to a maximum of about $1.1 \times 10^{5} \mathrm{~cm}^{-3}$ in a severely infected stand (Fig. $8 \mathrm{~h}$ ). Finally, it is predicted that herbivory by autumnal moth enhances the amount of produced particles by up to a factor of $\sim 2.7$, with a maximum number of particles in the growing mode of $\sim 3 \times 10^{4} \mathrm{~cm}^{-3}$ in an infested birch stand (Fig. 9j). The predicted amount of particles in a non-infested mountain birch stand is in the same order as observations from Finnish Lapland (Komppula et al., 2006). 


\subsubsection{New particle growth}

New particles are assumed to grow by sulfuric acid and OxOrg (Sect. 2.7, Eqs. 5-8); hence, the seasonal patterns of formation rates and OxOrg concentration are reflected in the pattern of the growth rates (Figs $6 \mathrm{~g}, 7 \mathrm{~h}, 8 \mathrm{~g}, 9 \mathrm{k}$ ) and therefore also in the season pattern of the number (Figs. 6f, $7 \mathrm{~g}$, $8 \mathrm{~h}, 9 \mathrm{j}$ ) and size (Figs. $6 \mathrm{~h}, 7 \mathrm{~g}, 8 \mathrm{~g}, 9 \mathrm{l}$ ) of the growing particle mode. We predict that the 10:00-16:00 LT median growth rate in an oak stand infested by gypsy moth is at maximum $\sim 5.9 \mathrm{~nm} \mathrm{~h}^{-1}$ under the assumed boundary conditions, whereas the corresponding growth rate in a non-infested oak stand is around $1.6 \mathrm{~nm} \mathrm{~h}^{-1}$, when the full leaf state has been attained (Fig. 6g). For comparison, the growth rate of new particles has been reported to range from 0.5 to $12 \mathrm{~nm} \mathrm{~h}^{-1}$ in Hyytiälä (Dal Maso et al., 2007), with median values of $2.1 \mathrm{~nm} \mathrm{~h}^{-1}$ (Vana et al., 2016), $2.5 \mathrm{~nm} \mathrm{~h}^{-1}$ (Dal Maso et al., 2007), and $3.3 \mathrm{~nm} \mathrm{~h}^{-1}$ (Paasonen et al., 2010), depending on which years the data covered. Dal Maso et al. (2007) reported that the growth rate of new small particles in Aspvreten, a rural site in Sweden dominated by deciduous and conifer forests and some farmlands, ranged between 1 and $11 \mathrm{~nm} \mathrm{~h}^{-1}$, with a median value of $3.4 \mathrm{~nm} \mathrm{~h}^{-1}$. The growth rate was found to range from 2.1 to $22.9 \mathrm{~nm} \mathrm{~h}^{-1}$, with a median value of $7.25 \mathrm{~nm} \mathrm{~h}^{-1}$ during spring in a mixed deciduous forest area close to Heidelberg, Germany, under the influence of anthropogenic pollution (Fiedler et al., 2005). Growth rates from an oak forest in Missouri, USA, were in the range 1.6-11.2 $\mathrm{nm} \mathrm{h}^{-1}$ (Yu et al., 2014). Median values for the growth rate have been reported to be $4.2 \mathrm{~nm} \mathrm{~h}^{-1}$ in Melpitz (Paasonen et al., 2010), $4.6 \mathrm{~nm} \mathrm{~h}^{-1}$ in Järvseljä (Vana et al., 2016), $4.8 \mathrm{~nm} \mathrm{~h}^{-1}$ in Hohenpeißenberg (Paasonen et al., 2010), and $9.5 \mathrm{~nm} \mathrm{~h}^{-1}$ in San Pietro Capofiume (Paasonen et al., 2010). Thus, we can conclude that our predicted growth rates are comparable to atmospheric observations from several different rural sites. Growth rates obtained from areas influenced by anthropogenic pollution are generally higher than our simulated rates, but this is expected since our model is constrained by conditions representative for rural sites.

Growth rates are predicted to be lower in an oak forest infected by oak powdery mildew than in an oak forest infested by gypsy moth. The rates are predicted to be (at a maximum) $\sim 2.0 \mathrm{~nm} \mathrm{~h}^{-1}$ (80\% of leaf area covered by mildew), $\sim 1.6 \mathrm{~nm} \mathrm{~h}^{-1}$ (30\% of leaf area covered by mildew), and $\sim 1.2 \mathrm{~nm} \mathrm{~h}^{-1}$ (non-infected, in the same environmental conditions as the infected trees) (Fig. 7h). Thus, the growth rates are similar to the lower end of the observed range.

The growth of small particles in non-infected and rustinfected poplar stands are predicted to range between $\sim 2.1$ and $\sim 5.7 \mathrm{~nm} \mathrm{~h}^{-1}$ during the late summer when the full leaf state has been attained, with the fastest growth in a heavily rust-infected forest stand (Fig. 8g). This range in growth rates is thus similar to simulation results of herbivory-infested oak (see above; Fig. 6g).
The predicted growth rates are smallest in simulations of non-infested mountain birch stands in Lapland. The 10:0016:00 LT median growth rate is at maximum predicted to be $\sim 1.4 \mathrm{~nm} \mathrm{~h}^{-1}$ in an infested stand and varies between $\sim 0.6$ and $\sim 2.0 \mathrm{~nm} \mathrm{~h}^{-1}$ in a non-infested stand (Fig. 9k). These values are in line with observations from Värriö (median of $1.6 \pm 0.9 \mathrm{~nm} \mathrm{~h}^{-1}$, Vana et al., 2016; monthly summer mean of 3.7-4.4 $\mathrm{nm} \mathrm{h}^{-1}$, Kyrö et al., 2014; range of $1-10 \mathrm{~nm} \mathrm{~h}^{-1}$ and median of $2.4 \mathrm{~nm} \mathrm{~h}^{-1}$, Dal Maso et al., 2007) and from Pallas, Finnish Lapland (median of $2.0 \mathrm{~nm} \mathrm{~h}^{-1}$ and daily range of $0.5-11 \mathrm{~nm} \mathrm{~h}^{-1}$, Dal Maso et al., 2007; monthly range of 1.9-4.6 $\mathrm{nm} \mathrm{h}^{-1}$, Asmi et al., 2011).

According to our predictions, new particles will grow up to about $46 \mathrm{~nm}$ larger in an oak stand infested by oak gypsy moth compared to a non-infested oak stand within $1 \mathrm{~d}$ (Fig. 6h). Simulation results for the other species and stressors show that new particles will grow up to about $8 \mathrm{~nm}$ more in a stand infected by oak powdery mildew (Fig. $7 \mathrm{~g}$ ), $\sim 28 \mathrm{~nm}$ more in a poplar stand infected by poplar rust (Fig. $8 \mathrm{~g}$ ), and $\sim 26 \mathrm{~nm}$ larger in a mountain birch stand infested by autumnal moth (Fig. 9l) within $1 \mathrm{~d}$ compared to their corresponding non-infected stands. In our simulations, the newly formed particles in non-infected oak stands are always mainly formed and grown by sulfuric acid (Figs. 6h, $7 \mathrm{~g}$ ), but in modelling of non-infected poplar, more than half of the formation and growth is due to HOM originating from isoprene (Fig. 8g), while HOM formed from monoterpenes account for a large fraction of the predicted formation and growth in non-infested birch stands (Fig. 91).

\subsubsection{R: the isoprene-to-monoterpenes carbon concentration ratio}

Previous chamber studies (Kiendler-Scharr et al., 2009, 2012; McFiggans et al., 2019; Heinritzi et al., 2020) have suggested that isoprene suppresses the formation of new particles from monoterpenes when the isoprene-to-monoterpene carbon concentration ratio (R) becomes too high. New particle formation has rarely been observed in the field when $R>1$ (e.g. Kanawade et al., 2011; Pöschl et al., 2010; Pöhlker et al., 2012; Lee et al., 2016). For example, Yu et al. (2014) observed formation of sub-5 $\mathrm{nm}$ particles during $64 \%$ of the measured days in an oak forest, though $R$ was $15.3 \pm 7.2$ during the campaign period. However, since the formation of new particles occurs on a regional scale, the authors suggested that the detected particles could have been formed at lower $R$ and advected to their measurement site. Contrarily, it has earlier been proposed that oxidation products of isoprene (e.g. IEPOX) promote the growth of existing new particles $\left(D_{\mathrm{p}}>3 \mathrm{~nm}\right.$, e.g. Surratt et al., 2010; Lin et al., 2013), while Heinritzi et al. (2020) observed the growth of particles above $3.2 \mathrm{~nm}$ to be unaffected by the concentration of isoprene. It is thus likely that the zone of $R$ values, inside which the probability for new particle formation to oc- 
cur changes, is influenced by other environmental factors and is therefore location and/or season dependent.

New particle formation has also been observed in the upper troposphere in tropical regions (Andreae et al., 2018; Williamson et al., 2019) where isoprene dominates the emission spectrum greatly. The hypothesis is that isoprene is vertically transported via strong convection and new particles are formed from isoprene oxidation products, which is possible due to lower-temperature conditions in the upper troposphere.

The concentration ratio of isoprene-to-monoterpene carbon is very high in non-infected oak and poplar stands and in oak stands that are no longer exposed to herbivory (Figs. 6b, $7 \mathrm{~d}, 8 \mathrm{~d}$ ), and it is therefore questionable whether particles will be formed at all in the atmospheric boundary layer from these stands when they are not experiencing stress. Biotic stress greatly reduces $R$ in all three cases. $R$ is most significantly decreased to a minimum 10:00-16:00 LT median value of 0.004 in simulations of oak stands infested by gypsy moth (Fig. 6b), but the period with low $R$ values is rather short. For example, $R<1$ during only 11 and $4 \mathrm{~d}$, respectively, while $R<22.5$ (probably the highest ratio at which new particles formation has been observed in the field, Yu et al., 2014) during 32 and $21 \mathrm{~d}$ in our simulations of oak stands that are severely and moderately infested, respectively, by European gypsy moth (Fig. 12e). $R$ is predicted to be close to 1 (though never below 1) in simulations of both oak stands infected by oak powdery mildew and rust-infected poplar stands. The duration where $R$ is, e.g. less than 22.5 is $39 \mathrm{~d}$ in a severely mildew-infected oak stand, $31 \mathrm{~d}$ in a moderately mildewinfected oak stand, and $27 \mathrm{~d}$ in a severely rust-infected poplar stand (Fig. 12e). For comparison, $R$ is never predicted to be less than 22.5 in a moderately infected poplar stand (Fig. 8d). Even if new particles are not formed from stands infected by oak powdery mildew or poplar rust in the boundary layer, then both the potential to form new particles in the upper troposphere (Figs. 7f, g, 8f, h) and the potential to grow already existing particles, which are formed in nearby stands and horizontally transported to the infected stands (Figs. $7 \mathrm{~g}, \mathrm{~h}, 8 \mathrm{~g}$ ), are still predicted to be greater than in our simulations of the correspondingly non-infected stands. $R$ is not relevant in the case of mountain birch, since this tree species does not emit isoprene constitutively or in response to herbivory stress by autumnal moth larvae (Yli-Pirilä et al., 2016; Rieksta et al., 2020).

\subsection{Estimating the reliability of our results}

Since aerosol processes are very sensitive to changes in environmental conditions, conditions that can vary greatly both interannually and from day to day, we investigated the influence of a wide range of realistic and relevant environmental conditions (Table D1 in Appendix D) on our model predictions (Figs. 10-11, D1-D2 in Appendix D). Nine different sensitivity tests (ST1-9) were conducted for all plant species and infections, where only one parameter was changed at a time (Table D1). For these simulations, the default values listed in Table 2 were used, while the default maximum daily temperature at Hohenpeißenberg and SMEAR I were assigned to 25 and $20^{\circ} \mathrm{C}$, respectively, and the default LAI for oak (and poplar) and birch was assumed to be 5 and $2 \mathrm{~m}^{2} \mathrm{~m}^{-2}$, respectively. All aerosol parameters (formation and growth rates, diameter, number of particles) show a similar response to changes in the considered environmental parameters, thus only the impact on the number of newly formed particles (Figs. 10-11) and the rate at which new small particles grow (Figs. D1-D2) is displayed.

As is also observed in nature, certain conditions suppress or prevent the formation of new particles, such as a high condensation sink (Fig. 11d, i, n, s; e.g. Hyvönen et al., 2005; Nieminen et al., 2015; Vana et al., 2016) and low sulfuric acid concentration (Fig. 11c, h, m, r; e.g. Boy et al., 2005; Nieminen et al., 2014), making the atmospheric relevance of the forest stands minor. Since we have assumed realistic conditions but at the same time conditions that do not prevent the formation of new particles in our simulations, the number of predicted days with occurring new particle formation is the theoretical maximum for clean environments, which our aerosol theory is based on (Sect. 2.7). Though the absolute number of predicted new particles depends highly on the assumed environmental conditions (Figs. 10-11), the relative difference between non-infected and stressed stands of the same tree species is not impacted; e.g. the number of new particles is always significantly higher in oak stands infested by gypsy moth and infected by oak powdery mildew than in non-infected oak stands when the environmental conditions are assumed to be the same in all stands (Figs. 10a-h, 11a-j). Likewise, more particles are always formed in moderately, than severely, moth infested oak and birch stands, since the decrease in LAI is stronger than the increase in the stressinduced emission response per unit leaf area (Figs. 10a-d, $\mathrm{m}-\mathrm{p}, 11 \mathrm{a}-\mathrm{e}, \mathrm{p}-\mathrm{t})$. This is emphasised in very severely infested mountain birch stands (e.g. $80 \%$ defoliation), where the number of produced particles is always less than in its corresponding non-infested stand (Figs. 10m-p, 11p-t).

Sensitivity tests were also carried out in order to assess whether the simplifications made in the model are valid.

1. As mentioned earlier (Sect. 2.4), we did not incorporate a full canopy environment in the model - an approach that has also been taken by other investigators (e.g. Simpson et al., 1999, 2012; Bergström et al., 2014). In ST2 (Table D1, Figs. 10b, f, j, n, D1b, f, j, n), changes in light conditions exclusively impact the predicted emissions of VOCs. From Figs. 10b, f, j, n, D1b, $\mathrm{f}, \mathrm{j}$, and $\mathrm{n}$ it is clear that even assuming extremely different light environments would not change our conclusions about the atmospheric importance of biotic plant stresses, since our results show that stressed forest with a maximum light availability down to $200 \mu \mathrm{mol} \mathrm{m}^{-2} \mathrm{~s}^{-1}$ 

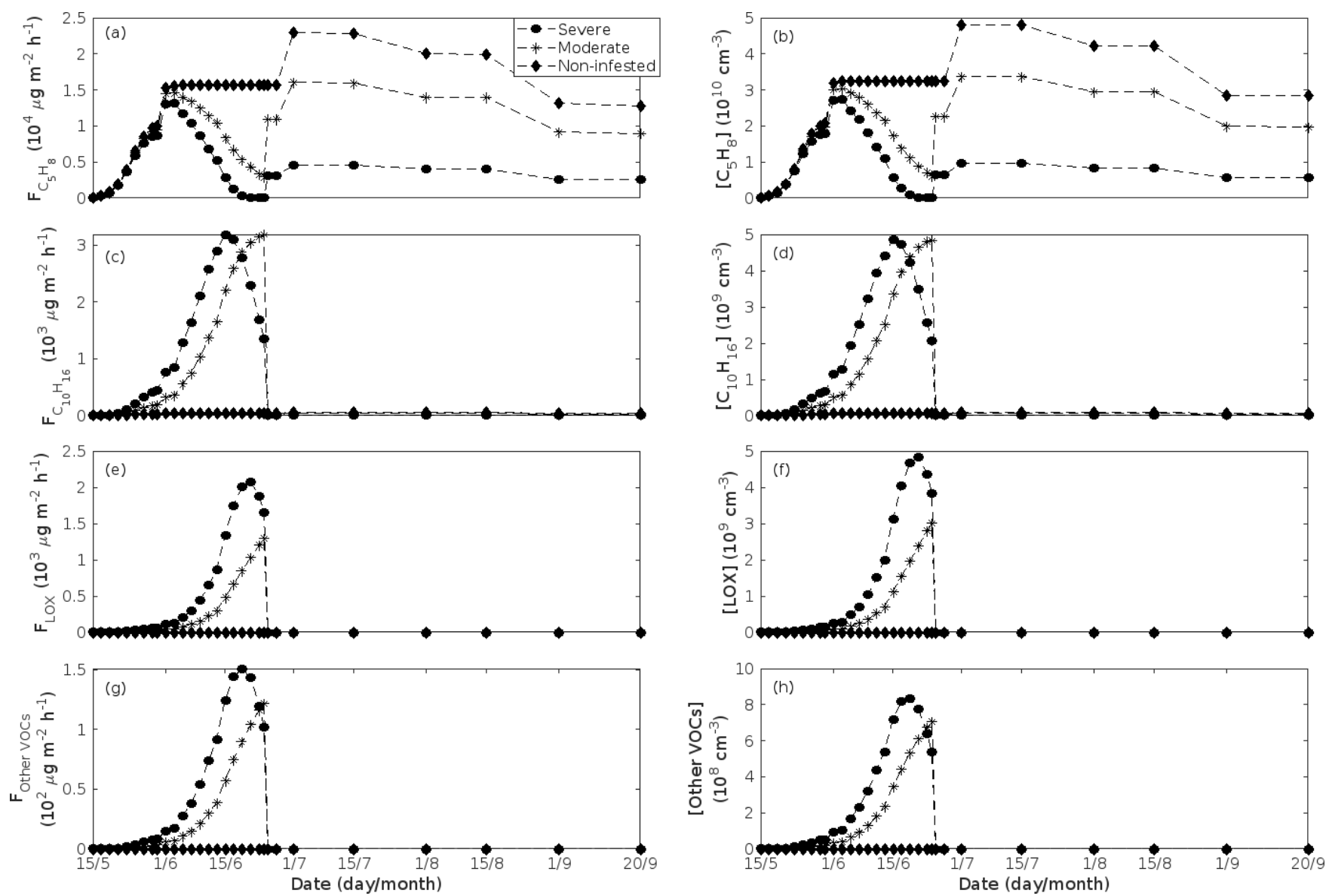

Figure 5. A pure oak stand infested with European gypsy moth larvae in comparison to a non-infested pure oak stand. Canopy emissions of (a) isoprene, (c) monoterpenes, (e) lipoxygenase pathway volatiles (LOX), and (g) the sum of other VOCs that contribute to OxOrg formation (i.e. methyl salicylate and dimethyl-nonatriene). Atmospheric concentrations of (b) isoprene, (d) monoterpenes, (f) lipoxygenase pathway volatiles, and (h) the sum of other VOCs which contribute to OxOrg formation. "Moderately" and "severely" refer to $30 \%$ and $80 \%$, respectively, of the leaf area that has been consumed by the end of the feeding period.

would still produce more new particles than its correspondingly non-infected stand at theoretically clear sky conditions (Fig. 10b, f, j, n). A mountain birch stand that is highly stressed by autumnal moth (80\% defoliation) would possibly produce slightly more particles than a non-infested stand if a full canopy environment would be considered. For example, the number of produced particles is slightly higher in a birch stand experiencing a stress level of $80 \%$ under $1000 \mathrm{umol} \mathrm{m}^{-2} \mathrm{~s}^{-1}$ than a non-infested stand under $400 \mu \mathrm{mol} \mathrm{m} \mathrm{m}^{-2} \mathrm{~s}^{-1}$ (Fig. 10n). However, the LAI of mountain birch stands is usually rather low (Heiskanen, 2006), making the difference in light environment between a non-infested and a highly defoliated stand small. Since mildew and rust do not decrease the leaf area of their host, a different treatment of the light environment would not influence the relative atmospheric importance of fungally infected oak and poplar vs. their corresponding non-infected stands (Fig. 10f, j).
2. In ST3 (Table D1, Figs. 10c, g, k, o, D1c, g, k, o) and in our seasonal simulations (Figs. 5-9), the change of temperature only impacts the emission rates of VOCs. In reality, the vapour pressures of oxidised compounds increase non-linearly with an increase in temperature (e.g Bilde et al., 2015), and less HOM and other oxidised organic compounds will therefore condense at higher temperatures, whereby the formation and subsequent growth of particles will decrease (Stolzenburg et al., 2018; Simon et al., 2020). Gas-phase chemistry, including the formation of HOM, is also in reality temperature dependent (e.g. Quéléver et al., 2019). These effects have not been included in the model. Since the range of daily maximum temperatures throughout the growing season is assumed to be rather narrow (Fig. 4), this effect does not greatly impact our results (Sect. 3.1), but it means that the number of particles produced at high temperatures (Fig. 10c, g, k, o) and the growth rate 

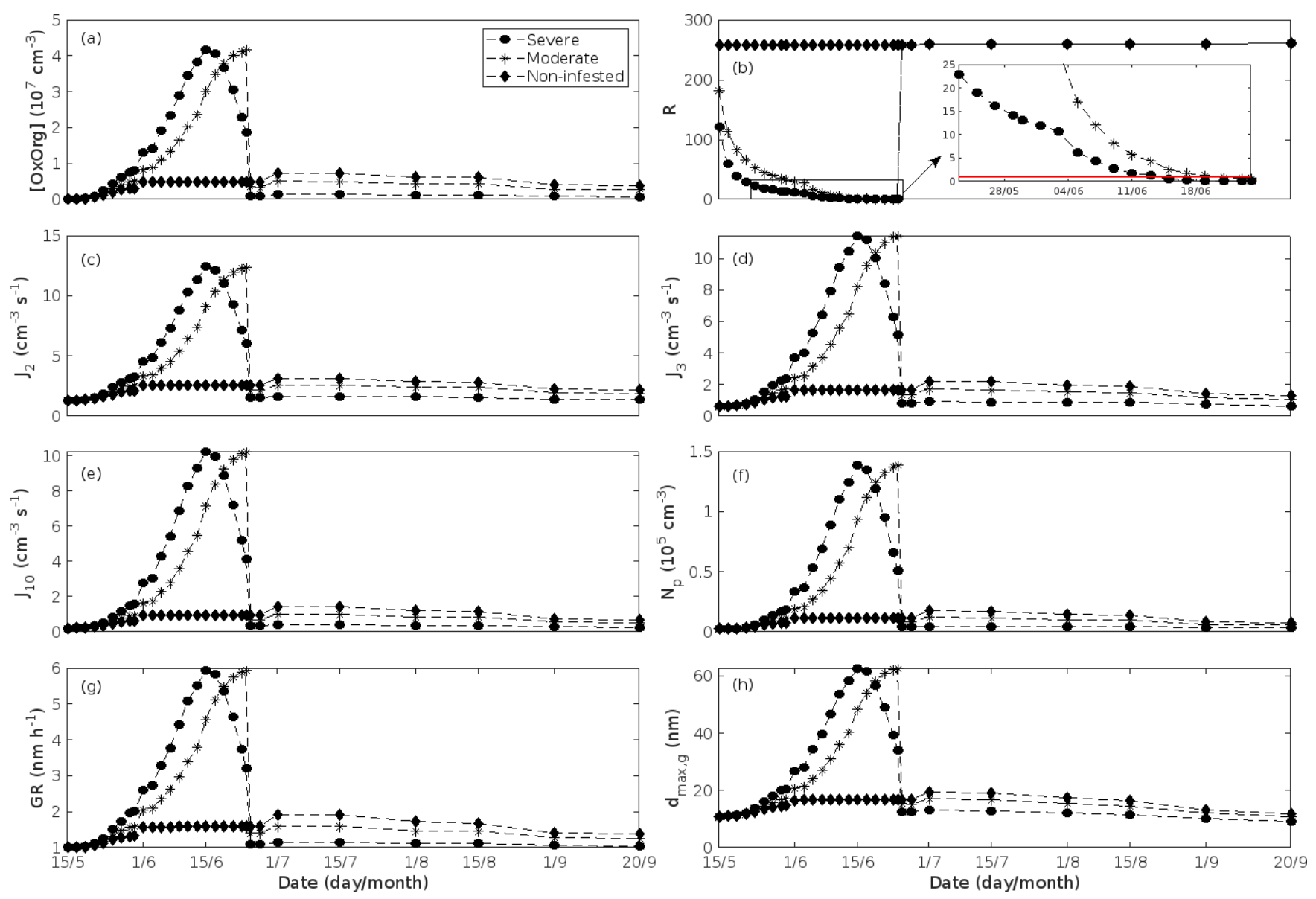

Figure 6. A pure oak stand infested with European gypsy moth larvae in comparison to a non-infested pure oak stand. (a) Atmospheric concentrations of OxOrg. (b) The ratios of isoprene-to-monoterpenes carbon concentrations, where the red line indicates $R=1$. Formation rates of (c) 2, (d) 3, and (e) $10 \mathrm{~nm}$ particles. (f) Number concentrations of formed particles, (g) growth rates of newly formed particles, and (h) the daily maxima diameter of the growing particle mode. "Moderately" and "severely" refer to $30 \%$ and $80 \%$, respectively, of the leaf area that has been consumed by the end of the feeding period.

at which they are produced (Fig. D1c, g, k, o) are overestimated for both non-infected and stressed forests.

3. The concentrations of ozone and $\mathrm{OH}$ were unaltered between simulations of non-infected forests and forests under varying degrees of infection (Sect. 2.6), although in reality the atmospheric oxidation capacity is controlled by changes in the concentration of atmospheric trace gases, including VOCs. The total emission of VOCs from oak and poplar stands is greatly dominated by isoprene, but the emission of isoprene decreases as a function of biotic stress severity (Figs. 5a, 7a, 8a). In contrast, the emission of LOX, methyl salicylate, methanol, monoterpenes, and sesquiterpenes increases as the level of stress increases (Figs. 5c, e, g, 7a, b, $8 \mathrm{a}, \mathrm{b})$. The oxidation of isoprene, LOX, methyl salicylate, and methanol is primarily driven by reactions with $\mathrm{OH}$, and monoterpenes also react with $\mathrm{OH}$, which all leads to reductions in the concentration of $\mathrm{OH}(\mathrm{Ta}-$ ble 3), although, e.g. ozonolysis of monoterpenes also produce $\mathrm{OH}$, which thus counters part of the reduction. When considering the reaction rates and emission rates of the considered VOCs in simulations of oak and poplar stands, the concentration of $\mathrm{OH}$ is mainly controlled by changes in the emission of isoprene. Thus, we expect that the concentration of $\mathrm{OH}$ will increase as the degree of stress increases, but even a strong shift in the concentration of $\mathrm{OH}$ will not change the conclusion about the relative atmospheric importance of stressed vs. stress-free oak and poplar forests (Figs. 11b, g, 1, q, D2b, g, l, q). The absolute number of predicted new particles in herbivory-stressed oak stands will, however, be predicted to be smaller at higher levels of $\mathrm{OH}$ (Fig. 11b) because the oxidation of monoterpenes is then more strongly controlled by $\mathrm{OH}$, which leads to a smaller production of $\mathrm{HOM}$, as monoterpenes typically form HOM at a considerably lower yield from reactions with $\mathrm{OH}$ than ozone (Appendix C). A similar 

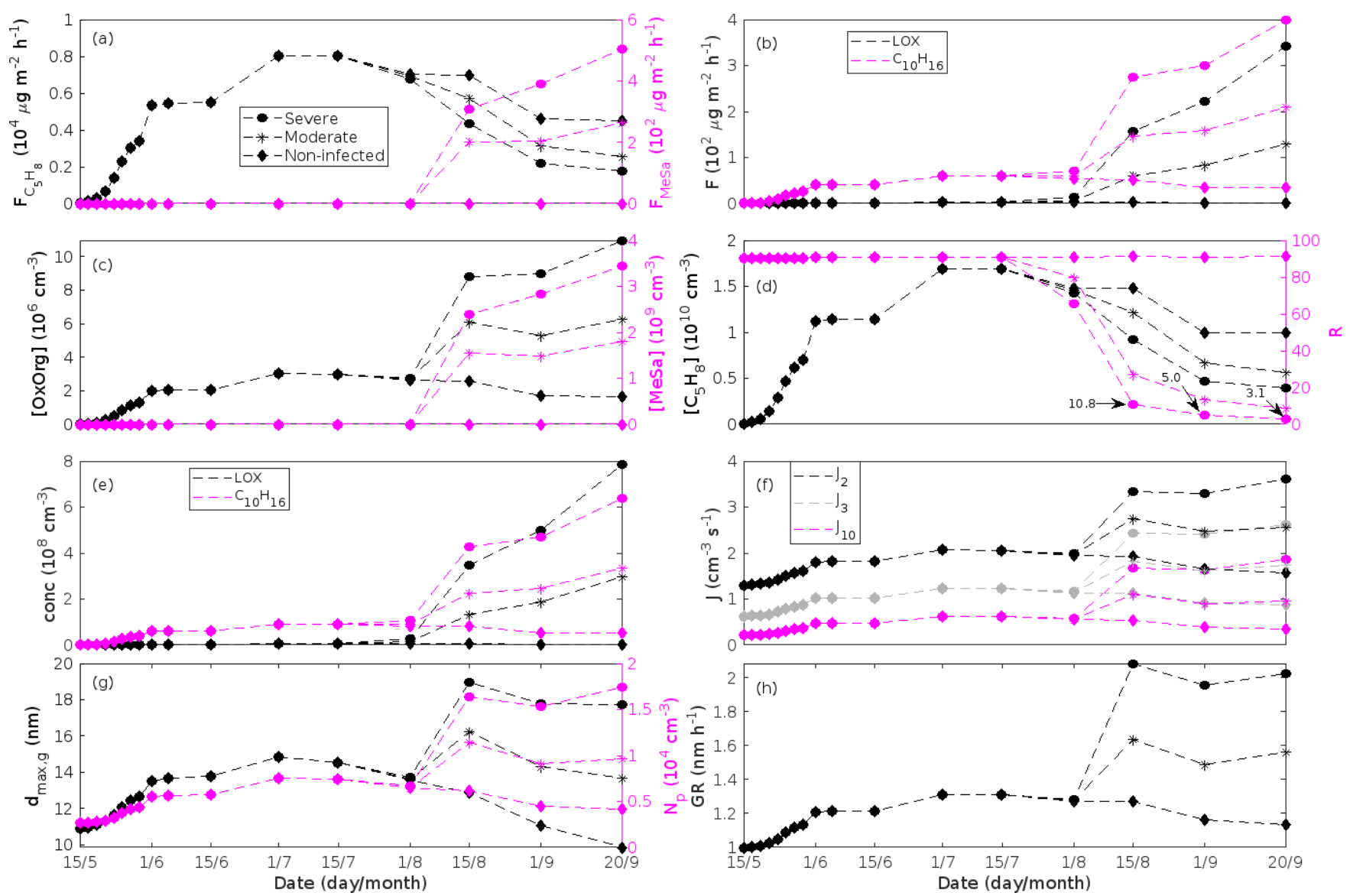

Figure 7. A pure oak stand infected by oak powdery mildew in comparison to a non-infected pure oak stand. Canopy emissions of (a, left axis) isoprene, (a, right axis) methyl salicylate, and (b) lipoxygenase pathway volatiles and monoterpenes. Atmospheric concentrations of (c, left axis) OxOrg, (c, right axis) methyl salicylate, (d, left axis) isoprene, and (e) lipoxygenase pathway volatiles and monoterpenes. (d, right axis) The ratios of isoprene-to-monoterpene carbon concentrations. (f) Formation rates of 2, 3, and $10 \mathrm{~nm}$ particles. (g, left axis) Daily maxima diameter of the growing particle mode and (g, right axis) number concentrations of formed particles. (h) Growth rates of newly formed particles. "Moderately" and "severely" refer to $30 \%$ and $80 \%$, respectively, of the leaf area that has been infected by fungi by the onset of senescence.

shift in the oxidation of monoterpenes is happening in case of oak infected by oak powdery mildew, but the effect is counted by an increase in the formation of oxidised organic compounds from oxidation of methyl salicylate at high levels of $\mathrm{OH}$, leading to higher predicted particle number concentrations (Fig. 11g). Considering the emissions from biotically stressed and non-infested mountain birch, we estimate that the concentration of $\mathrm{OH}$ should stay largely the same or potentially decrease slightly at higher levels of infestation, which will enhance the oxidation of monoterpenes by ozone and lead to a larger production of HOM and thereby a slightly higher predicted number of new particles (Fig. 11q). In the atmosphere, the production of sulfuric acid is limited by the availability of $\mathrm{OH}$, and it is therefore possible that the effects of changes in the concentration of $\mathrm{OH}$ (Fig. 11b, q) and sulfuric acid (Fig. 11c, r) in herbivorystressed stands on the absolute number of predicted new particles will cancel out or even lead to a stronger particle production than predicted. In case of oak infected by oak powdery mildew, the two effects will enhance each other and result in an even higher number of predicted particles. In clean, low- $\mathrm{NO}_{x}$ environments, which we aimed to simulate, the concentration of ozone is largely unaffected by the ambient concentration of isoprene (e.g. Jenkin et al., 2015). However, isoprene forms ozone progressively with an increased availability of $\mathrm{NO}_{x}$ (e.g. Jenkin and Clemitshaw, 2000). Higher ozone levels support enhanced formation of HOM and thus aerosol processes, but the production of HOM is also known to decrease as a function of increased $\mathrm{NO}_{x}$ concentration (e.g. Ehn et al., 2014), whereby the formation and growth of new particles becomes suppressed (e.g. Yan et al., 2020; Pullinen et al., 2020). 

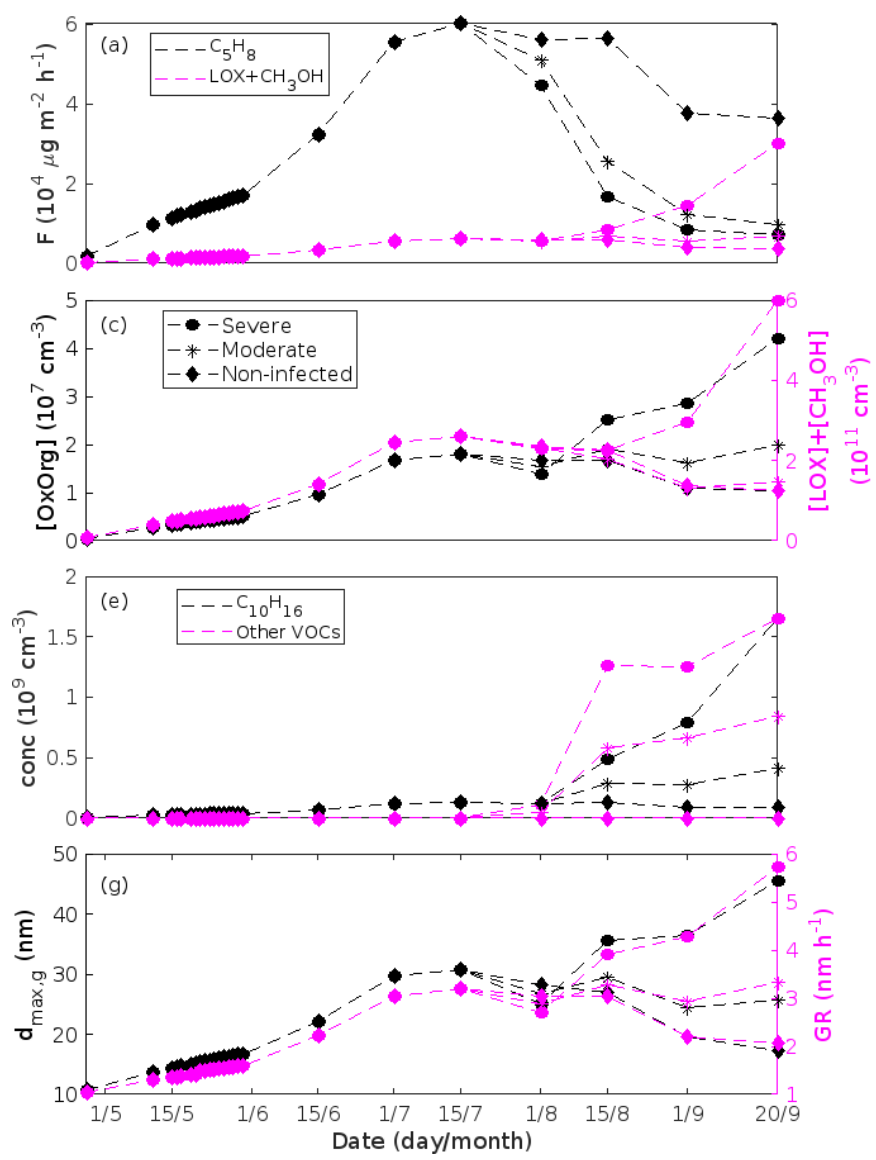
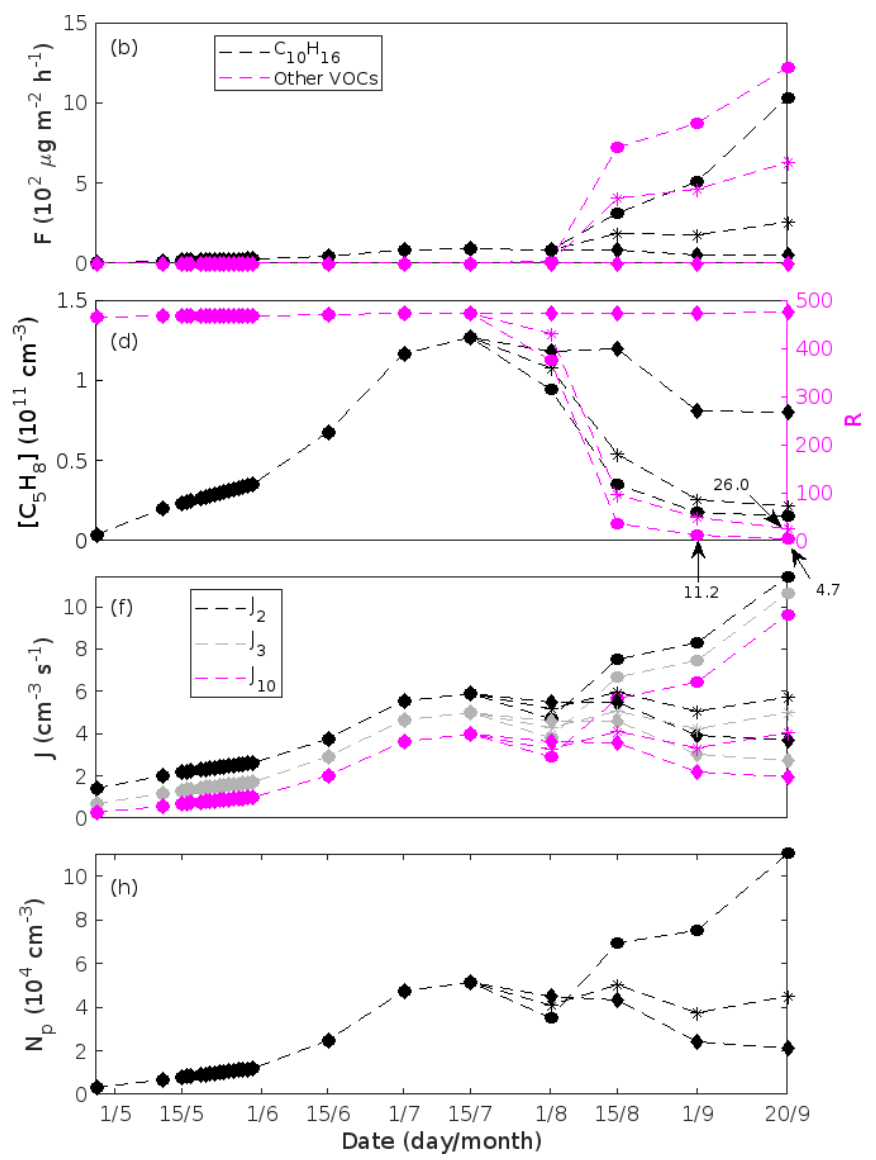

Figure 8. A pure poplar stand infected by rust fungi in comparison to a non-infected pure poplar stand. Canopy emissions of (a) isoprene and the sum of lipoxygenase pathway volatiles and methanol and (b) monoterpenes and the sum of other VOCs that contribute to OxOrg formation (i.e. methyl salicylate, dimethyl-nonatriene, $\alpha$-Eudesmol, and sesquiterpenes). Atmospheric concentrations of (c, left axis) OxOrg, (c, right axis) the sum of lipoxygenase pathway volatiles and methanol, (d, left axis) isoprene, and (e) monoterpenes and the sum of other VOCs that contribute to OxOrg formation. (d, right axis) The ratios of isoprene-to-monoterpene carbon concentrations. (f) Formation rates of 2, 3, and $10 \mathrm{~nm}$ particles. (g, left axis) Daily maxima diameter of the growing particle mode and (g, right axis) growth rates of newly formed particles. (h) Number concentrations of formed particles. "Moderately" and "severely" refer to $30 \%$ and $80 \%$, respectively, of the leaf area that has been infected by fungi by the onset of senescence.

4. As mentioned earlier (Sect. 2.6), many HOM yields have not been investigated for the exact compounds that are emitted from the tree species, which are the focus of this study. From Fig. 11e, j, o, and $t$ it is obvious that even if all the OxOrg yields used for simulations of only biotically stressed forests were to be decreased significantly - in cases of moderately herbivory-infested oak (30\% of leaf area defoliated) by down to about $95 \%$ - biotically stressed oak, poplar, and mountain birch forests would still, in most cases, produce more particles than non-infected forests of the same tree species. The yields at which HOM are formed have been treated as fixed values (Appendix C) in the seasonal simulations (Sect. 3.1), but the yields actually depend on several factors, such as the concentration of $\mathrm{NO}_{x}$ (point 3 above; Ehn et al., 2014), temperature (point 3 above; Quéléver et al., 2019; Simon et al., 2020), and the ambi- ent blend of VOCs (Sect. 3.1.5; McFiggans et al., 2019). Exactly how the formation and growth of new particles depend on the VOC blend is still uncertain, but it has recently been demonstrated that a linear addition of the yields from the individual yields of components in the VOC mixture will result in an overestimation of both the number and size of particles (McFiggans et al., 2019). As we have followed a similar procedure, this effect might cause our predicted aerosol processes (Sect. 3.1) to be overestimated, but since the ratio of isoprene-tomonoterpenes carbon concentration is much higher in non-infected oak and poplar stands than in the correspondingly stressed stands (Figs. 6b, 7d, 8d), the overestimation is expected to be more pronounced in the noninfected stands (McFiggans et al., 2019). The difference in the atmospheric importance of non-infected and bi- 

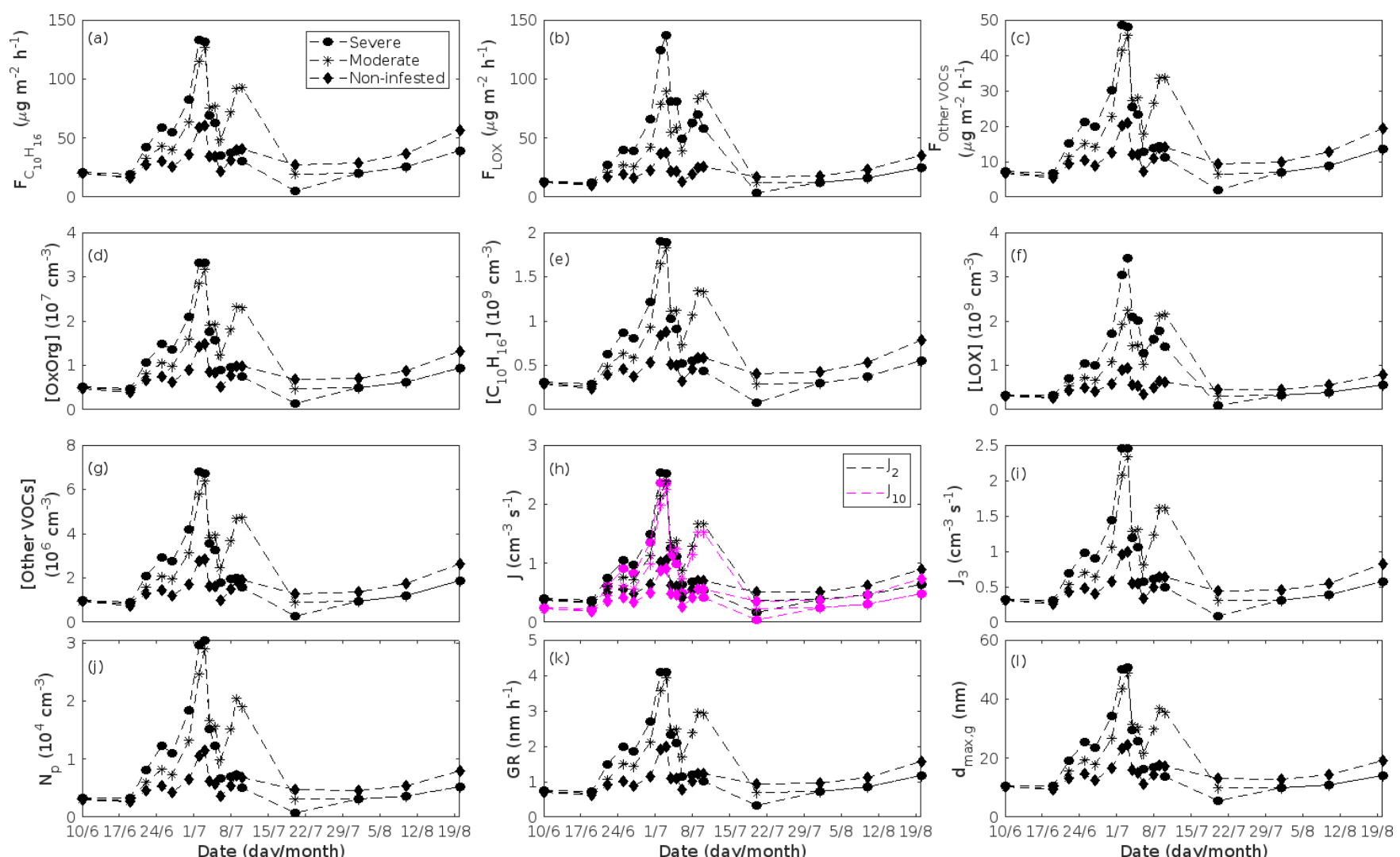

Figure 9. A pure mountain birch stand infested with autumnal moth larvae in comparison to a non-infested pure mountain birch stand. Canopy emissions of (a) monoterpenes, (b) lipoxygenase pathway volatiles, and (c) the sum of other VOCs that contribute to OxOrg formation (here i.e. dimethyl-nonatriene and sesquiterpenes). Atmospheric concentrations of (d) OxOrg, (e) monoterpenes, (f) lipoxygenase pathway volatiles, and (g) the sum of other VOCs which contribute to OxOrg formation. Formation rates of (h) 2, 10, and (i) $3 \mathrm{~nm}$ particles. (j) Number concentrations of formed particles. (k) Growth rates of newly formed particles. (l) Daily maxima diameter of the growing particle mode. "Moderately" and "severely" refer to $30 \%$ and $80 \%$, respectively, of the leaf area that has been consumed by the end of the feeding period.

otically stressed oak and poplar stands thereby widens (Fig. 11e, j, o).

It is well known that the potential for foliage to emit VOCs depends on the age of the foliage: emerging and growing foliage usually emits isoprene at reduced rates (e.g. Guenther et al., 1991, 2012; Goldstein et al., 1998; Petron et al., 2001) and monoterpenes at enhanced rates (e.g. Guenther et al., 1991, 2012; Aalto et al., 2014; Taipale et al., 2020) compared to that of its corresponding mature foliage. Old leaves do usually additionally emit isoprene at decreased rates (Monson et al., 1994; Schnitzler et al., 1997; Sun et al., 2012). These effects were not considered in our simulations (Sect. 3.1) since the effect of leaf age on biotic plant stress emissions is unexplored. Considering a similar treatment of the impact of leaf maturity on the emissions of VOCs as Guenther et al. (2012) (see Appendix B) would only influence the predicted number and size of particles in herbivory-stressed and non-infested oak forests insignificantly (Fig. B2). However, it would decrease the ratio of isoprene-to-monoterpenes carbon so significantly in oak stands infested by gypsy moth that the possible suppression of aerosol processes by isoprene would disappear during most of the duration (or even the entire duration) of the stress (Fig. B2b). Applying a similar leaf age effect as described in Guenther et al. (2012) on simulations of fungally infected oak and poplar forests would not decrease the ratio of isoprene-to-monoterpenes carbon sufficiently in order to avoid the possible suppression effect of isoprene, since Guenther et al. (2012) only assume a reduction of $10 \%$ on the emissions of isoprene from old leaves. We investigated that the emission of isoprene from mildewinfected oak would need to decrease by $\sim 68 \%-96 \%$ (severity of stress ranging from $80 \%-9 \%$ ) in comparison to simulations where the leaf age effect is not considered in order to reach $R \leq 1$, whereas the emission of isoprene from noninfected oak would need to decrease by $\sim 99 \%$ (Fig. B3a). In comparison, the emission of isoprene from a non-infected poplar stand would need to decline by $99.8 \%$ and from a rust-infected poplar stand by at least $79 \%$ in order to attain $R \leq 1$ (Fig. B4a). In order to reach $R \leq 22.5$, the upper limit at which new particle formation has been observed in the at- 
mosphere (Yu et al., 2014), the emission of isoprene from a non-infected poplar stand would need to decrease by $\sim 95 \%$, whereas heavily rust-infected poplar forest would already be below this limit without considering an age-dependent reduction of the emission potential (Fig. B4a). Simulations were not done for mountain birch forest stands, since no emissions are suppressed upon herbivory stress of mountain birch (YliPirilä et al., 2016) and since Yli-Pirilä et al. (2016) did not provide age information on the leaves they measured.

\subsection{Implications and remaining issues to be explored}

Our simulation results (Figs. 5-9) illustrate that biotic plant stresses are capable of substantially perturbing both the number and size of atmospheric aerosol particles throughout a significant fraction of the year (summarised in Fig. 12). Considering that we calculated daily new particle growth, our results point to the direction that induced plant emissions will subsequently lead to more efficient $\mathrm{CCN}$ production in the atmosphere (Fig. 12), which will moreover affect cloud properties such as cloud albedo and lifetime (Twomey, 1977; Albrecht, 1989; Gryspeerdt et al., 2014; Rosenfeld et al., 2014). The amplitude of the enhancement, however, depends strongly on the specific stressor and tree species that are attacked.

Naturally, both the duration of stress (Fig. 12e) and the predicted number (Fig. 12d) and size (Fig. 12c) of new particles depend highly on our assumptions about, e.g. when the fungi start to attack their host, how fast the fungi spread, whether the larval eggs hatch simultaneously with budburst, how fast larval development occurs, and when senescence onsets, all of which depend strongly on environmental conditions. It is furthermore probable that emissions are also induced from fungally infected leaves during senescence, which was not simulated here. The duration of stress can thus be significantly longer than what is summarised in Fig. 12e, whereby the post-defoliation period, in cases of herbivory infestations, will also be shorter and the atmospheric importance of the stresses stronger.

We have also shown that it can be more important to account for biotic plant stresses in models for local and regional predictions of new particle formation and growth during the time of infestation or infection than significant variations in those environmental parameters that predictions of VOC emissions are currently controlled by, e.g. light conditions (Fig. 10b, f, j, n), temperature (Fig. 10c, g, k, o), and LAI (Fig. 10d, h, 1, p). Considering changes in the emissions of VOCs caused by stress also seems to be more crucial than accounting for large changes in the concentrations of $\mathrm{O}_{3}$ (Fig. 11a, f, k, p) and $\mathrm{OH}$ (Fig. 11b, g, 1, q).

Considering the frequency and scale of the investigated biotic stresses is important in order to properly evaluate the impact of the stresses on the atmosphere and climate: fungi are largely ubiquitous and account for $\sim 10 \%$ of all yearly recorded damage symptoms on trees growing in European forests (ICP Forests, 2020). To put that number in perspective, $\sim 87 \%$ of all investigated broadleaved trees ( $>50000)$ are reported yearly to have damage symptoms in European forests (ICP Forests, 2020). Considering the duration of stress and the predicted increase in the number and size of atmospheric aerosol particles in response to fungal infections, together with the fact that oak powdery mildew in particular is one of the most common plant diseases, with e.g. $\sim 9 \%$ of pedunculate and sessile oak reported to be infected by powdery mildew in Europe yearly (ICP Forests, 2020), our findings call for initiatives to account for fungal stress emission responses in numerical models in a robust manner. Though larvae are present every summer, the population density of both gypsy and autumnal moths is cyclic, with 8-10 years or 4-5 years between gypsy moth outbreaks depending on the forest type (mesic vs. xeric sites; Johnson et al., 2006), and 911 years between autumnal moth outbreaks (Haukioja et al., 1988; Ruohomäki et al., 2000; Ylivinkka et al., 2020). Gypsy moth is estimated to have defoliated $>38$ million ha of forest in North America alone during the period from 1920 to 2020 (Coleman et al., 2020), and gypsy moth larvae are usually reported to defoliate between $\sim 0.2-0.8$ million ha of forested land yearly in the US but with values as high as $\sim 5$ million ha $\mathrm{yr}^{-1}$ (Karel and Man, 2017). In comparison, the total area of forested land in the US is $\sim 333$ million ha (https: //www.fs.usda.gov, last access: 26 November 2021). In European forests, the mean level of defoliation of pedunculate and sessile oak is reported to be $\sim 27 \%$ yearly, while most of the trees are $10 \%-25 \%(\sim 39 \%$ of trees $)$ or $25 \%-40 \%$ defoliated ( $\sim 28 \%$ of trees, ICP Forests, 2020$)$. In comparison, only $\sim 19 \%$ of deciduous temperate oak trees in European forests are reported yearly as having a defoliation level ranging between 0-10\% (ICP Forests, 2020). Since European gypsy moth is one of the major defoliating insects feeding on pedunculate oak (https://www.cabi.org/isc/datasheet/31807\# tohostsOrSpeciesAffected, last access: 11 June 2021), it must be reasonable to assume that a significant fraction of the reported defoliation is caused by feeding by gypsy moth larvae, and thus it is likely that accounting for stress emissions in response to feeding by gypsy moth larvae is important for realistic predictions of new particle formation and growth. It is also likely that the reported defoliation that is not caused by gypsy moth larvae but instead by other herbivores also impacts new particle formation, though to which direction and with which amplitude this occurs is currently unknown. When the larval density of autumnal moth in Fennoscandia is low, the level of defoliation usually remains less than $15 \%$ (Bylund 1995), but during outbreak years large areas (in the order of several thousands of square kilometres) can become either completely or severely defoliated (e.g. Ruohomäki et al., 2000; Tenow 1975; Nikula, 1993). Thus, considering the scale of autumnal moth infestation combined with our findings about both the order of the increase in atmospheric new particle formation and growth caused by autumnal moth infestations, and also the absolute number and size of newly 

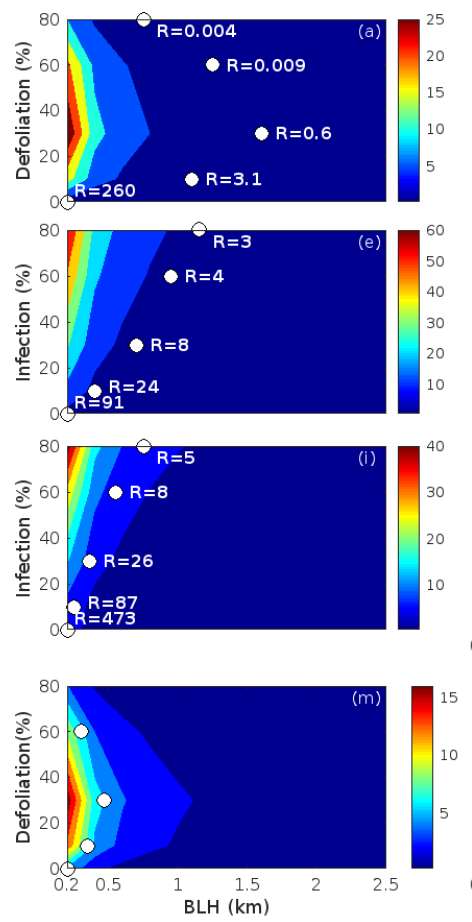
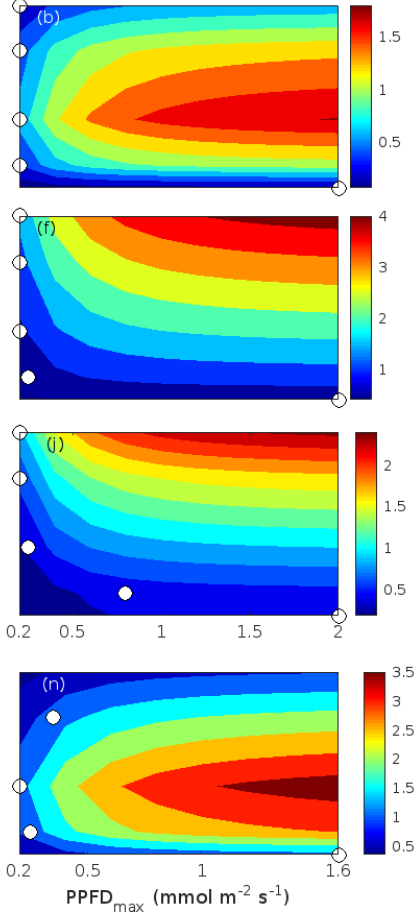
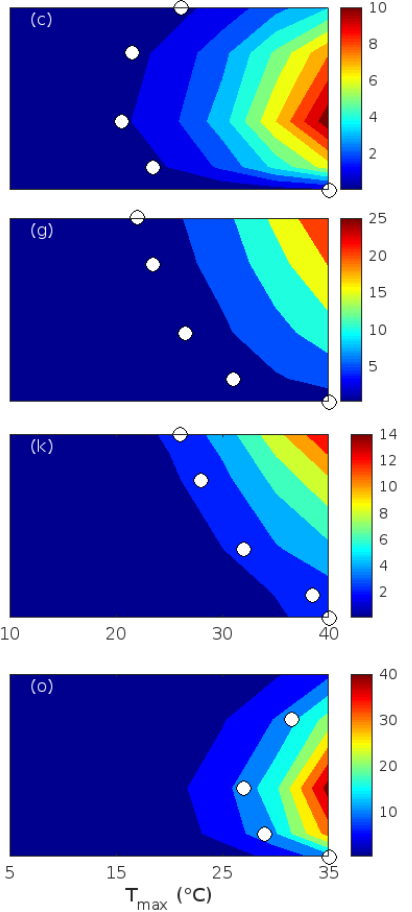
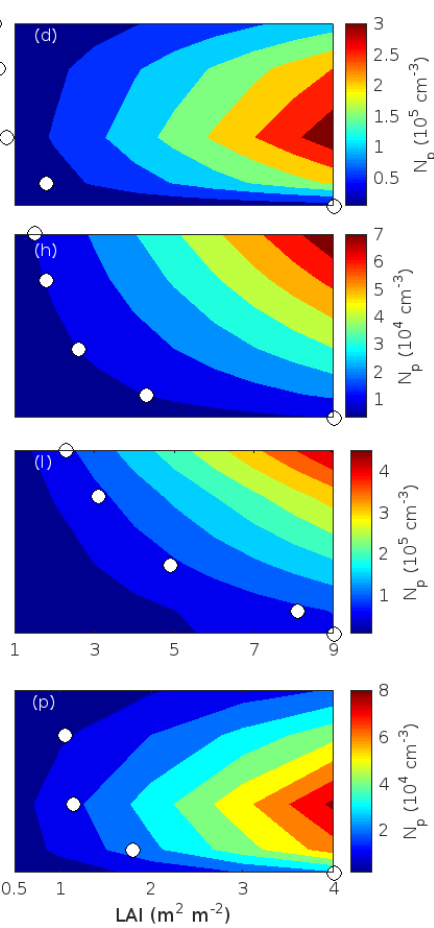

Figure 10. Impact of changed boundary conditions on the number concentrations of newly formed particles in non-infected and biotically stressed forest stands. The number concentration of newly formed particles is expressed as a function of changes in the boundary layer height $(\mathbf{a}, \mathbf{e}, \mathbf{i}, \mathbf{m})$, light $(\mathbf{b}, \mathbf{f}, \mathbf{j}, \mathbf{n})$, temperature $(\mathbf{c}, \mathbf{g}, \mathbf{k}, \mathbf{o})$, and leaf area index $(\mathbf{d}, \mathbf{h}, \mathbf{l}, \mathbf{p})$ for non-infected and infected oak (a-d, gypsy moth; e-h, powdery mildew), poplar (i-l), and birch $(\mathbf{m}-\mathbf{p})$ stands. Light $(\mathbf{b}, \mathbf{f}, \mathbf{j}, \mathbf{n})$ and temperature $(\mathbf{c}, \mathbf{g}, \mathbf{k}, \mathbf{o})$ are given as the daily maxima, but in the simulations the parameters follow a daily cycle. The displayed LAI $(\mathbf{d}, \mathbf{h}, \mathbf{l}, \mathbf{p})$ is that of a non-infected stand; e.g. at $\mathrm{LAI}=7 \mathrm{~m}^{2} \mathrm{~m}^{-2}$, the simulation for a larval infestation level of $80 \%$ has been conducted with LAI $=1.4 \mathrm{~m}^{2} \mathrm{~m}^{-2}$, which is $20 \%$ of the non-infected stand LAI value. Optimal conditions (i.e. leading to highest number concentrations) for non-infected stands are indicated with white markers at an infection level of $0 \%$. White markers located at various infection levels mark the conditions at which an identical or slightly higher number concentration, as produced by a non-infected forest stand at optimal conditions, is reached. No markers are used for $80 \%$ defoliated mountain birch (m-p), since the corresponding number concentrations are always lower than in a non-infested birch stand at optimal conditions. Be aware that white markers in (d) and (p) are not located at the LAI of a non-infected stand but instead at the values used for the simulations. $R$ values $(\mathbf{a}, \mathbf{e}, \mathbf{i})$ indicate the ratio of isoprene carbon/monoterpene carbon at the locations of the write markers. Be aware that the $x$ axes are different for simulations in Hohenpeißenberg (a-l) and SMEAR I conditions ( $\mathbf{m}-\mathbf{p})$ except in the case of changing boundary layer height (a, e, $\mathbf{i}, \mathbf{m})$.

formed particles, it could seem that the importance of accounting for autumnal moth infestation in models to predict aerosol formation is minor. It should, however, be emphasised that in our simulations we did not account for delayed defence responses that mountain birches are known to possess (e.g. Kaitaniemi et al., 1998; Ruuhola et al., 2007) and that possibly cause elevated total particle concentrations for a few years after larval infestation (Ylivinkka et al., 2020). In addition, we did not take multiple co-occurring stresses into account, which are often the rule in nature and which generally enhance the already induced emission response due to biotic plant stress (e.g. Blande et al., 2007; Vapaavuori et al., 2009; Holopainen and Gershenzon, 2010; Kivimäenpää et al., 2016; Ghimire et al., 2017). For example, Li et al. (2019) recently showed that warming significantly amplifies the emission response due to autumnal moth feeding. Thus, there is a great need for new field observations in or- der to validate modelling studies such as ours and in general to quantify the role of stress emissions in the formation and subsequent growth of new particles. This is especially important because enclosure studies, which currently are close to the only published measurements studies that have investigated the ability of biotic plant stress to influence aerosol processes, often do not accurately represent what is observed on canopy to landscape scales. In addition to this, robust representations of stress emissions and the drivers of the emissions are needed before it is possible to integrate stress emissions into large-scale models without introducing errors in the models. 

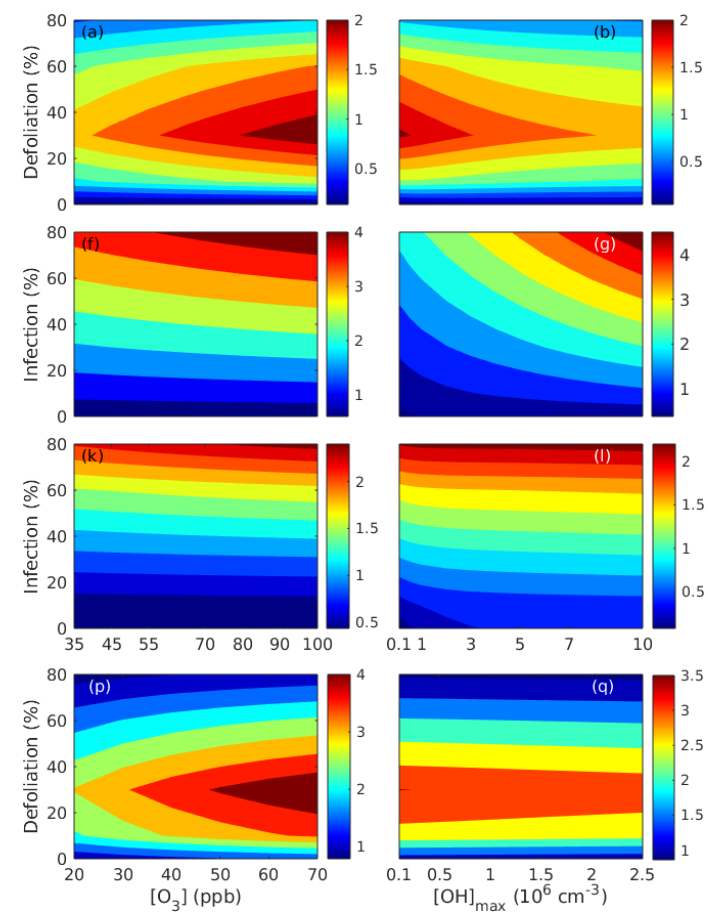
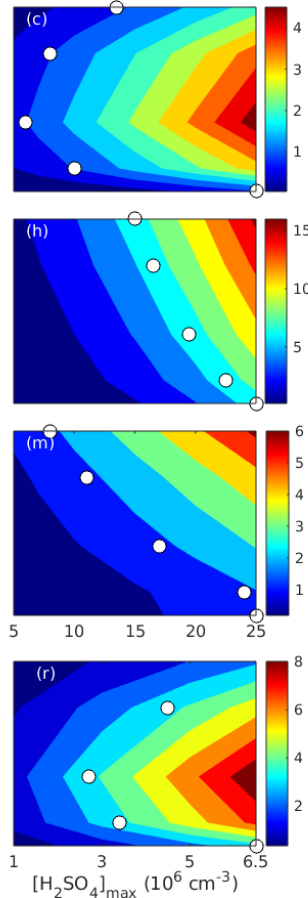
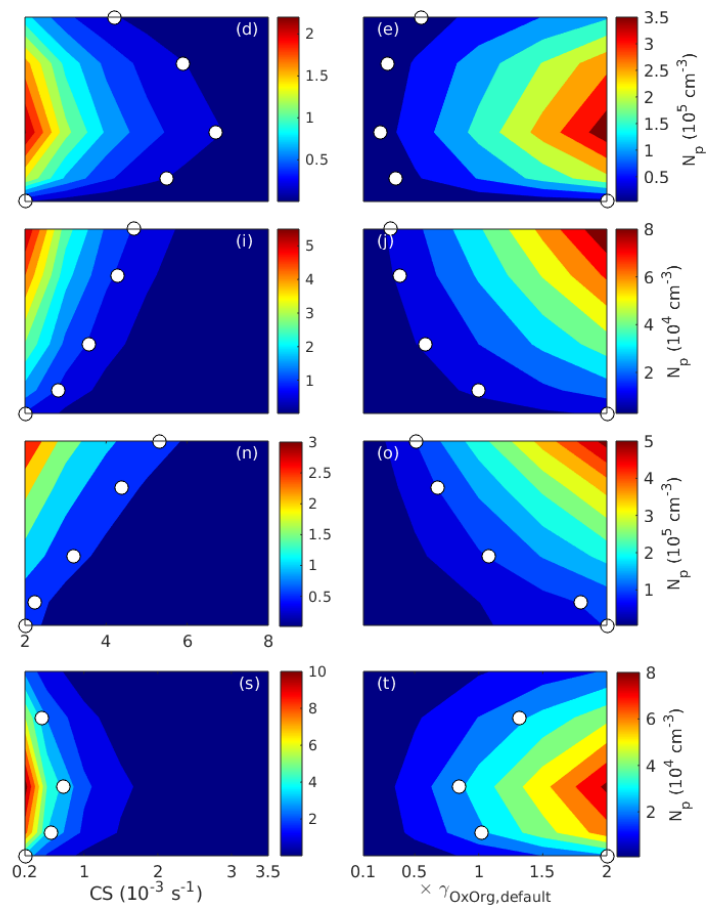

Figure 11. Impact of changed boundary conditions on the number concentrations of newly formed particles in non-infected and biotically stressed forest stands. The number concentration of newly formed particles is expressed as a function of changes in the concentration of ozone $(\mathbf{a}, \mathbf{f}, \mathbf{k}, \mathbf{p}), \mathrm{OH}(\mathbf{b}, \mathbf{g}, \mathbf{l}, \mathbf{q})$, and sulfuric acid $(\mathbf{c}, \mathbf{h}, \mathbf{m}, \mathbf{r})$, the condensation sink $(\mathbf{d}, \mathbf{i}, \mathbf{n}, \mathbf{s})$ and OxOrg yields $(\mathbf{e}, \mathbf{j}, \mathbf{o}, \mathbf{t})$ for non-infected and infected oak (a-e, gypsy moth, $\mathbf{f}-\mathbf{j}$, powdery mildew), poplar (k-o), and birch (p-t) stands. The concentrations of $\mathrm{OH}(\mathbf{b}, \mathbf{g}, \mathbf{l}, \mathbf{q})$ and sulfuric acid $(\mathbf{c}, \mathbf{h}, \mathbf{m}, \mathbf{r})$ are given as the daily maxima, but in the simulations the parameters follow a daily cycle. White markers are used in a similar way as in Fig. 10. Be aware that the $x$ axes are different for simulations in Hohenpeißenberg (a-o) and SMEAR I conditions (p-t) except in the case of changing OxOrg yields $(\mathbf{e}, \mathbf{j}, \mathbf{o}, \mathbf{t})$.

\section{Conclusions}

We constructed a conceptual model to simulate new particle formation and growth in various broadleaved forest stands in clean low $\mathrm{NO}_{x}$ environments under biotically stressed and stress-free conditions throughout a full growing season. Unsurprisingly, we found that the predicted atmospheric importance of biotic plant stress highly depends on the specific individual stressor and tree species that are attacked. Thus, the amount of newly formed particles was predicted to be up to about an order of magnitude higher in an oak stand infested by gypsy moth than in a non-infested oak stand. In comparison, the number of new particles was simulated to be up to about a factor of 3, 4, and 5 higher in mountain birch, pedunculate oak, and balsam poplar stands infected by autumnal moth, oak powdery mildew, and poplar rust, respectively. We furthermore predicted that the new particles will grow up to about $46,28,26$, and $8 \mathrm{~nm}$ larger in an oak stand infested by gypsy moth, a poplar stand infected by rust, a mountain birch stand infested by autumnal moth, and in an oak stand infected by oak powdery mildew, respectively, compared to their corresponding non-infected stands within $1 \mathrm{~d}$. To our knowledge, this study is the first to investigate the at- mospheric impact of biotic plant stresses throughout a full growing season.

Our modelling results generally indicate that all the investigated plant stresses are capable of substantially perturbing both the number and size of atmospheric aerosol particles, and it is thus likely that the induced emissions will subsequently lead to more efficient $\mathrm{CCN}$ production in the atmosphere. We also showed that it can be more important to account for biotic plant stresses in models for local and regional predictions of new particle formation and growth during the time of infestation or infection than significant variations in, e.g. LAI and temperature and light conditions, which are currently the main parameters controlling predictions of VOC emissions. Considering our findings together with the fact that insect outbreaks and fungal diseases are generally expected to increase in both frequency and severity in the future, our study underlines the need for new field measurements to quantify the role of stress emissions in atmospheric aerosol processes and for making integration of biotic plant stress emission responses into numerical models possible. 

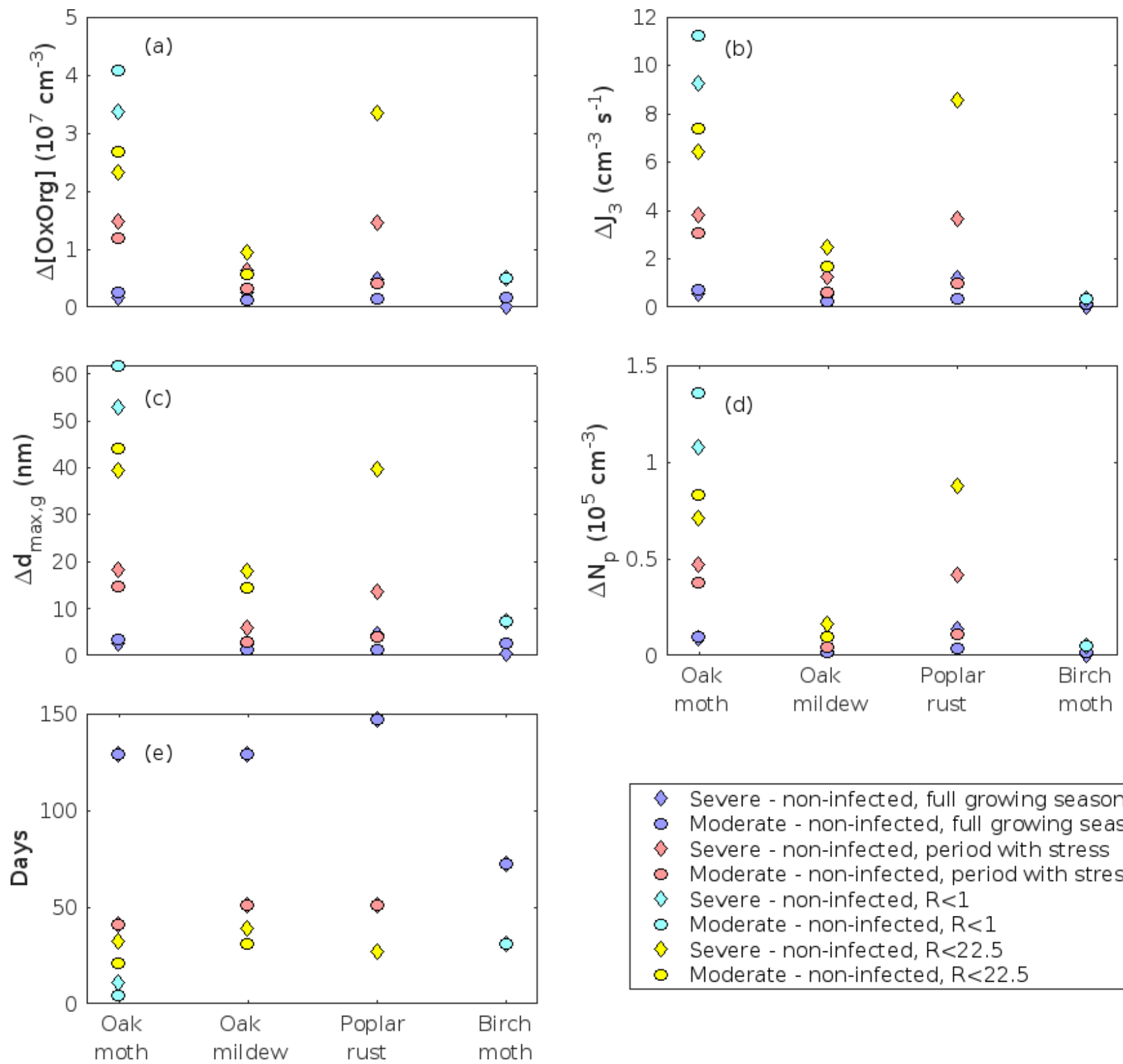

\begin{tabular}{|ll|}
\hline & Severe - non-infected, full growing season \\
& Moderate - non-infected, full growing season \\
$\diamond$ & Severe - non-infected, period with stress \\
& Moderate - non-infected, period with stress \\
$\diamond$ & Severe - non-infected, $\mathrm{R}<1$ \\
& Moderate - non-infected, $\mathrm{R}<1$ \\
$\diamond$ & Severe - non-infected, $\mathrm{R}<22.5$ \\
& Moderate - non-infected, $\mathrm{R}<22.5$
\end{tabular}

Figure 12. Differences in atmospheric response from various non-infected and biotically stressed plant species. (a) Atmospheric concentrations of OxOrg, (b) formation rates of $3 \mathrm{~nm}$ particles, (c) daily maximum diameter of the growing particle mode, (d) number concentration of formed particles, and (e) amount of days considered. Panels (a)-(d) are provided as the differences between the averaged parameter in a stressed and stress-free forest stand of the same plant species type. Differences and averages are considered based on the complete growing season, the period with stress, when the ratio of isoprene-to-monoterpenes carbon concentration is less than 1 or less than 22.5 . Be aware that $R$ is always zero in simulations of birch. In cases where $R$ does not reach less than 1 or less than 22.5 in the atmosphere surrounding a non-infected forest stand but does in the case of the corresponding stressed stand, it is assumed that the atmospheric parameter in the noninfected stand is zero, and hence the difference is given as the value of the stressed stand. The concentration differences of OxOrg, formation rates, and number concentrations are calculated based on an average, for the period of interest, of the median values during 10:00-16:00 LT. "Severe" and "moderate" refer to $80 \%$ or $30 \%$ of the total leaf area having been consumed or infected by the end of the feeding or infection period, respectively. Southern Germany has been used as border conditions for simulations of oak and poplar, while SMEAR I (Finnish Lapland) has been used for modelling of birch. 


\section{Appendix A: Emission factors at a few different degrees}

\section{of stress}

The emission factors utilised in our simulations depend on the degree of stress. The equations to calculate the emission factors, as a function of the degree of stress, are presented in Table 1 in the main paper. In this appendix, the emission factors at a few different degrees of stress are shown (Table A1). $25^{\circ} \mathrm{C}$ and $1000 \mu \mathrm{mol} \mathrm{m}^{-2} \mathrm{~s}^{-1}$ are here considered standard conditions (see Sect. 2.4).

Table A1. Emission factors $\left(\varepsilon_{i, E}\right.$, in nmol m ${ }^{-2}$ one-sided LAI s $\left.{ }^{-1}\right)$ at a few different degrees of stress ( $\left.A E\right)$. ISO stands for isoprene, MT stands for monoterpenes, MeSa stands for methyl salicylate, LOX stands for lipoxygenase pathway volatile compounds, DMNT stands for 4,8-dimethyl-1,3,7-nonatriene, MeOH stands for methanol, SQT stands for sesquiterpenes, and $\alpha$-Eud stands for $\alpha$-Eudesmol.

\begin{tabular}{l} 
Infestation of pedunculate oak (Quercus robur) by European \\
gypsy moth (Lymantria dispar) based on Copolovici et al. (2017). \\
\hline E $(\%)$
\end{tabular}

Infection of pedunculate oak (Quercus robur) by oak powdery mildew (Erysiphe alphitoides) based on Copolovici et al. (2014).

\begin{tabular}{lrrrrr}
\hline$A E(\%)$ & 0 & 10 & 30 & 60 & 80 \\
$\varepsilon_{\text {iso }}\left(\mathrm{nmol} \mathrm{m}^{-2} \mathrm{~s}^{-1}\right)$ & 10.6 & 8.50 & 6.04 & 4.79 & 4.17 \\
$\varepsilon_{\mathrm{MT}}\left(\mathrm{nmol} \mathrm{m}^{-2} \mathrm{~s}^{-1}\right)$ & 0.0400 & 0.120 & 0.247 & 0.386 & 0.471 \\
$\varepsilon_{\mathrm{MeSa}}\left(\mathrm{nmol} \mathrm{m}^{-2} \mathrm{~s}^{-1}\right)$ & 0.0 & 0.136 & 0.279 & 0.437 & 0.533 \\
$\varepsilon_{\mathrm{LOX}}\left(\mathrm{nmol} \mathrm{m}^{-2} \mathrm{~s}^{-1}\right)$ & 0.00213 & 0.0645 & 0.189 & 0.377 & 0.501 \\
\hline Infection of balsam poplar $($ Populus balsamifera var. suaveolens $)$ by & \\
poplar rust $($ Melampsora larici-populina $)$ based on Jiang et al. $(2016)$. & \\
\hline E $(\%)$ & 0 & 10 & 30 & 60 & 80 \\
$\varepsilon_{\text {iso }}\left(\mathrm{nmol} \mathrm{m}^{-2} \mathrm{~s}^{-1}\right)$ & 86.0 & 36.8 & 22.8 & 17.9 & 16.6 \\
$\varepsilon_{\mathrm{MT}}\left(\mathrm{nmol} \mathrm{m}^{-2} \mathrm{~s}^{-1}\right)$ & 0.0625 & 0.145 & 0.302 & 0.762 & 1.22 \\
$\varepsilon_{\mathrm{MeSa}}\left(\mathrm{nmol} \mathrm{m}^{-2} \mathrm{~s}^{-1}\right)$ & 0.0 & 0.0552 & 0.128 & 0.194 & 0.249 \\
$\varepsilon_{\mathrm{LOX}}\left(\mathrm{nmol} \mathrm{m}^{-2} \mathrm{~s}^{-1}\right)$ & 0.481 & 1.96 & 3.96 & 11.8 & 19.8 \\
$\varepsilon_{\mathrm{DNMT}}\left(\mathrm{nmol} \mathrm{m}^{-2} \mathrm{~s}^{-1}\right)$ & 0.0 & 0.0199 & 0.0460 & 0.0698 & 0.0898 \\
$\varepsilon_{\text {MeOH }}\left(\mathrm{nmol} \mathrm{m}^{-2} \mathrm{~s}^{-1}\right)$ & 16.9 & 14.9 & 19.0 & 45.6 & 76.9 \\
$\varepsilon_{\mathrm{SQT}}\left(\mathrm{nmol} \mathrm{m}^{-2} \mathrm{~s}^{-1}\right)$ & 0.0 & 0.133 & 0.308 & 0.468 & 0.602 \\
$\varepsilon_{\alpha \text {-Eud }}\left(\mathrm{nmol} \mathrm{m}^{-2} \mathrm{~s}^{-1}\right)$ & 0.0 & 0.0219 & 0.0507 & 0.0768 & 0.0989 \\
\hline
\end{tabular}

Infestation of mountain birch (Betula pubescens var. pumila) by autumnal moth (Epirrita autumnata) based on Yli-Pirilä et al. (2016).

\begin{tabular}{lrrrrr}
\hline$E(\%)$ & 0 & 10 & 30 & 60 & 80 \\
$\varepsilon_{\text {MT }}\left(\mathrm{nmol} \mathrm{m}^{-2} \mathrm{~s}^{-1}\right)$ & 0.131 & 0.278 & 0.423 & 0.475 & 0.485 \\
$\varepsilon_{\text {LOX }}\left(\mathrm{nmol} \mathrm{m}^{-2} \mathrm{~s}^{-1}\right)$ & 0.0868 & 0.200 & 0.425 & 0.764 & 0.989 \\
$\varepsilon_{\text {DNMT }}\left(\mathrm{nmol} \mathrm{m}^{-2} \mathrm{~s}^{-1}\right)$ & 0.00122 & 0.00662 & 0.0125 & 0.0148 & 0.0153 \\
$\varepsilon_{\text {SQT }}\left(\mathrm{nmol} \mathrm{m}^{-2} \mathrm{~s}^{-1}\right)$ & 0.0437 & 0.0926 & 0.141 & 0.158 & 0.161 \\
\hline
\end{tabular}




\section{Appendix B: Leaf age effect}

\section{B1 Simulations of pedunculate oak infested with European gypsy moth larvae}

It seems likely that Copolovici et al. (2017) conducted their measurements on leaves that emit isoprene at peak rate, since their reported emission rate of isoprene from non-infested leaves is comparable to the rates reported from mature leaves in previous studies (e.g. Smiatek and Steinbrecher, 2006; Perez-Rial et al., 2009; van Meeningen et al., 2016). The impact of leaf age was tested during the period with stress utilising the modifications shown in Table B1. The first period covers the number of days between bud break and the induction of isoprene emission, while the second period ends when initiation of peak isoprene emission rates has been reached. The duration of these two periods were calculated using Eqs. (18a) and (19) in Guenther et al. (2006) and our assumptions about the ambient temperature conditions (Fig. 4b). Since isoprene does not show an induced response in emission upon gypsy moth herbivory, the emission rate of isoprene was reduced in simulations of both non-infested and infested oak forest. The applied factors used for reductions are from Guenther et al. (2012). The emission rate of monoterpenes was increased in the beginning of the growing season for simulations of a non-infested oak stand utilising the coefficients from Guenther et al. (2012). Stress-induced emissions were not altered since we do not know the effect of leaf age on these types of emissions and Guenther et al. (2012) also assumed the same. The results are shown in Figs. B1-B2.

\section{B2 Simulations of pedunculate oak infected by oak powdery mildew and balsam poplar infected by rust fungi}

The emission rates used for simulations of oak and poplar with and without pathogenic infection were measured in the middle and at the beginning of September, respectively, in Estonia (Copolovici et al., 2014; Jiang et al., 2016). Representative photographs of control leaves indicate that the measured leaves were mature and without any visible signs of senescence (Copolovici et al., 2014; Jiang et al., 2016).

When leaves grow old, they eventually lose their ability to photosynthesise and produce isoprene (Monson et al., 1994; Schnitzler et al., 1997; Sun et al., 2012), and Guenther et al. (2012) assumed a reduction of $10 \%$ in the emissions of isoprene from senescing leaves (compared to that of mature leaves). However, a reduction on such a scale (i.e. $10 \%$ ) is not sufficient to decrease the ratio of isoprene-tomonoterpene carbon concentration to less than 1 in our simulations of oak and poplar infected by fungi. The impact of leaf age was therefore tested during the period with stress by decreasing the emission rate of isoprene to such a degree that $R$ was either just under 22.5 or just under 1 . Since isoprene does not show an induced response in emission upon oak powdery mildew or rust infection, the emission rate of isoprene was reduced in simulations of both non-infected and stressed oak and poplar forest. The results are shown in Figs. B3-B4.

Table B1. Modifications done in order to consider the effect of leaf age. $\varepsilon_{\text {isoprene }}$ and $\varepsilon$ monoterpenes are the emission factors of isoprene and monoterpenes, respectively, used in the simulations when the leaf age effect has been considered, while $\varepsilon_{\text {iso,mature }}$ and $\varepsilon_{\text {mono,mature }}$ are the emission factors of isoprene and monoterpenes, respectively, used in the default simulations (i.e. resulting in Figs. 5-6). The modifications have been applied to the simulations of either only non-infested oak or both non-stressed and stressed oak as indicated under "simulations".

\begin{tabular}{lllll}
\hline Time period & $\varepsilon_{\text {isoprene }}$ & Simulations & $\varepsilon_{\text {monoterpenes }}$ & Simulations \\
\hline 15-26 May & $0.05 \times \varepsilon_{\text {iso, mature }}$ & $\begin{array}{l}\text { Non-infested, moderate } \\
\text { stress, severe stress }\end{array}$ & $2 \times \varepsilon_{\text {mono, mature }}$ & Non-infested \\
\hline 27 May-11 June & $0.6 \times \varepsilon_{\text {iso, mature }}$ & $\begin{array}{l}\text { Non-infested, moderate } \\
\text { stress, severe stress }\end{array}$ & $1.8 \times \varepsilon_{\text {mono, mature }}$ & Non-infested \\
\hline 12 June- & $\varepsilon_{\text {iso, mature }}$ & $\begin{array}{l}\text { Non-infested, moderate } \\
\text { stress, severe stress }\end{array}$ & $\varepsilon_{\text {mono, mature }}$ & $\begin{array}{l}\text { Non-infested, moderate } \\
\text { stress, severe stress }\end{array}$ \\
\hline
\end{tabular}



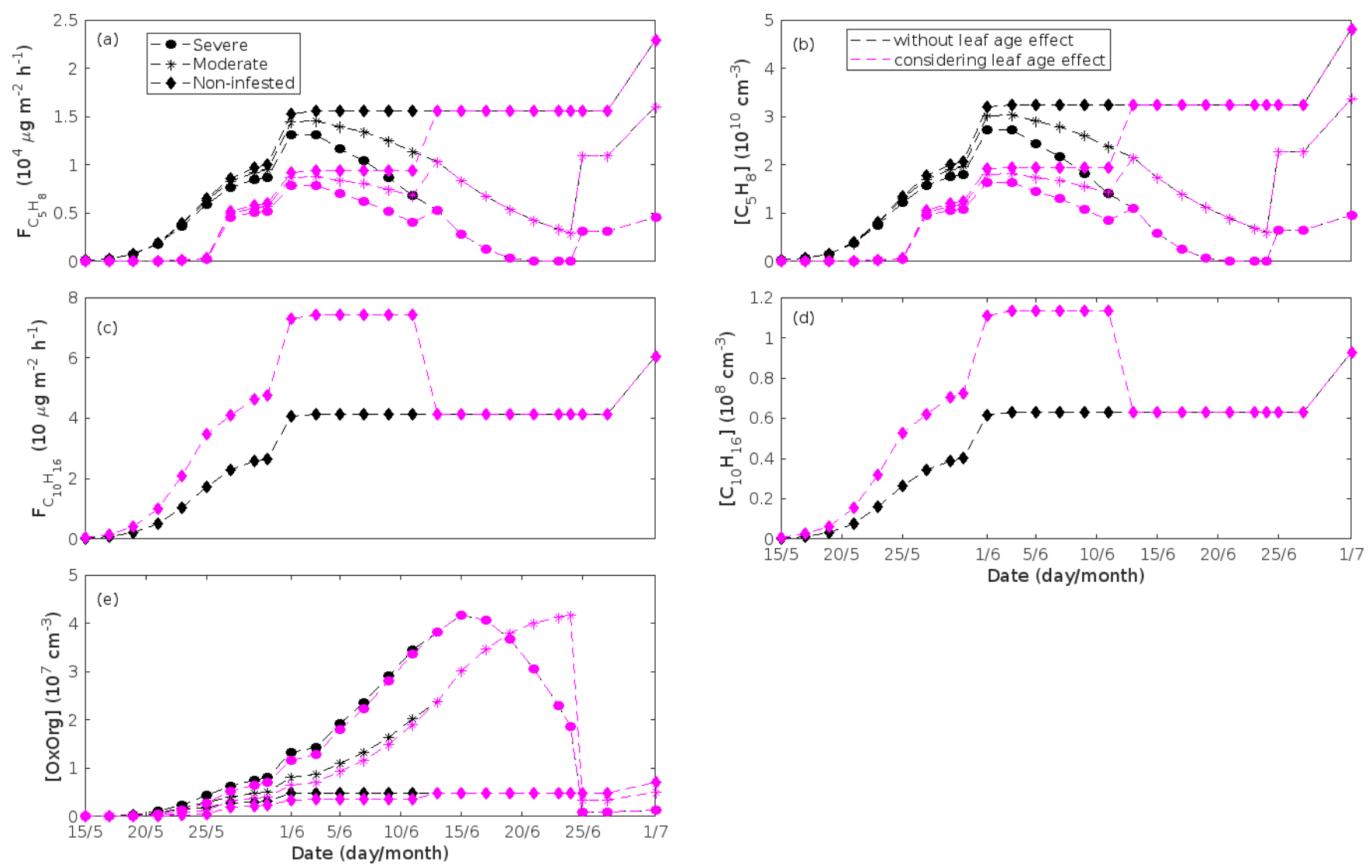

Figure B1. An oak stand infested with European gypsy moth larvae in comparison to a non-infested oak stand simulated with and without considering the impact of leaf age on the rates of emissions. Canopy emissions of (a) isoprene and (c) monoterpenes and atmospheric concentrations of (b) isoprene, (d) monoterpenes, and (e) OxOrg. "Moderately" and "severely" refer to $30 \%$ and $80 \%$, respectively, of the leaf area having been consumed by the end of the feeding period. Black markers are for simulations where the effect of leaf age was not considered, while magenta markers are for simulations where the effect of leaf age was considered. Simulation results for severe are always indicated by circles, by asterisks for moderate, and by diamonds for non-infested (independent of whether the effect of leaf age was considered or not). 

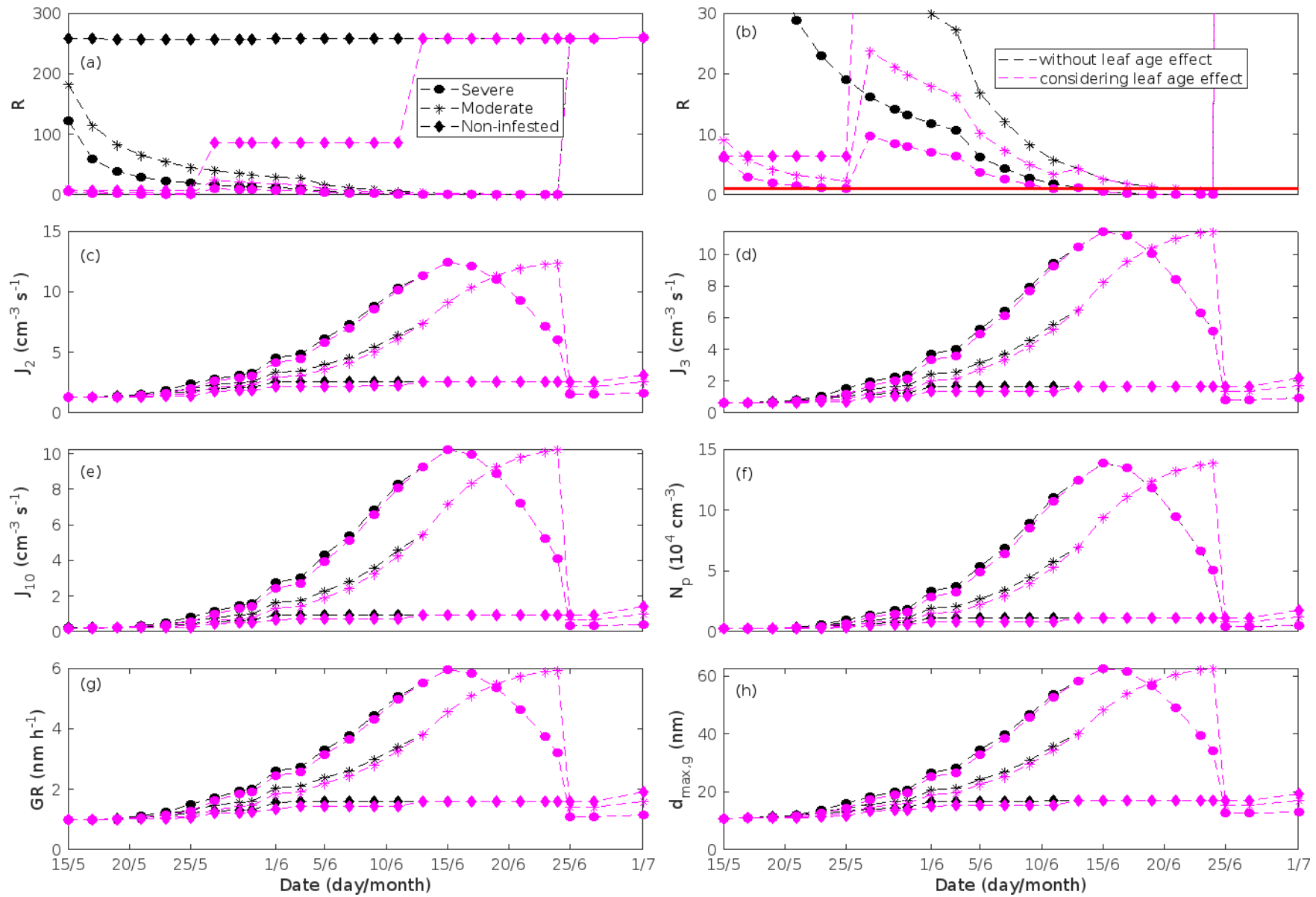

Figure B2. An oak stand infested with European gypsy moth larvae in comparison to a non-infested oak stand simulated with and without considering the impact of leaf age on the rates of emissions. (a) The ratios of isoprene-to-monoterpene carbon concentrations are provided as a zoom in (b), where the red line indicates $R=1$. Formation rates of (c) 2, (d) 3, and (e) $10 \mathrm{~nm}$ particles. (f) Number concentrations of formed particles, $(\mathbf{g})$ growth rates of newly formed particles, and (h) the daily maxima diameter of the growing particle mode. Symbols are used in the same way as in Fig. B1. 

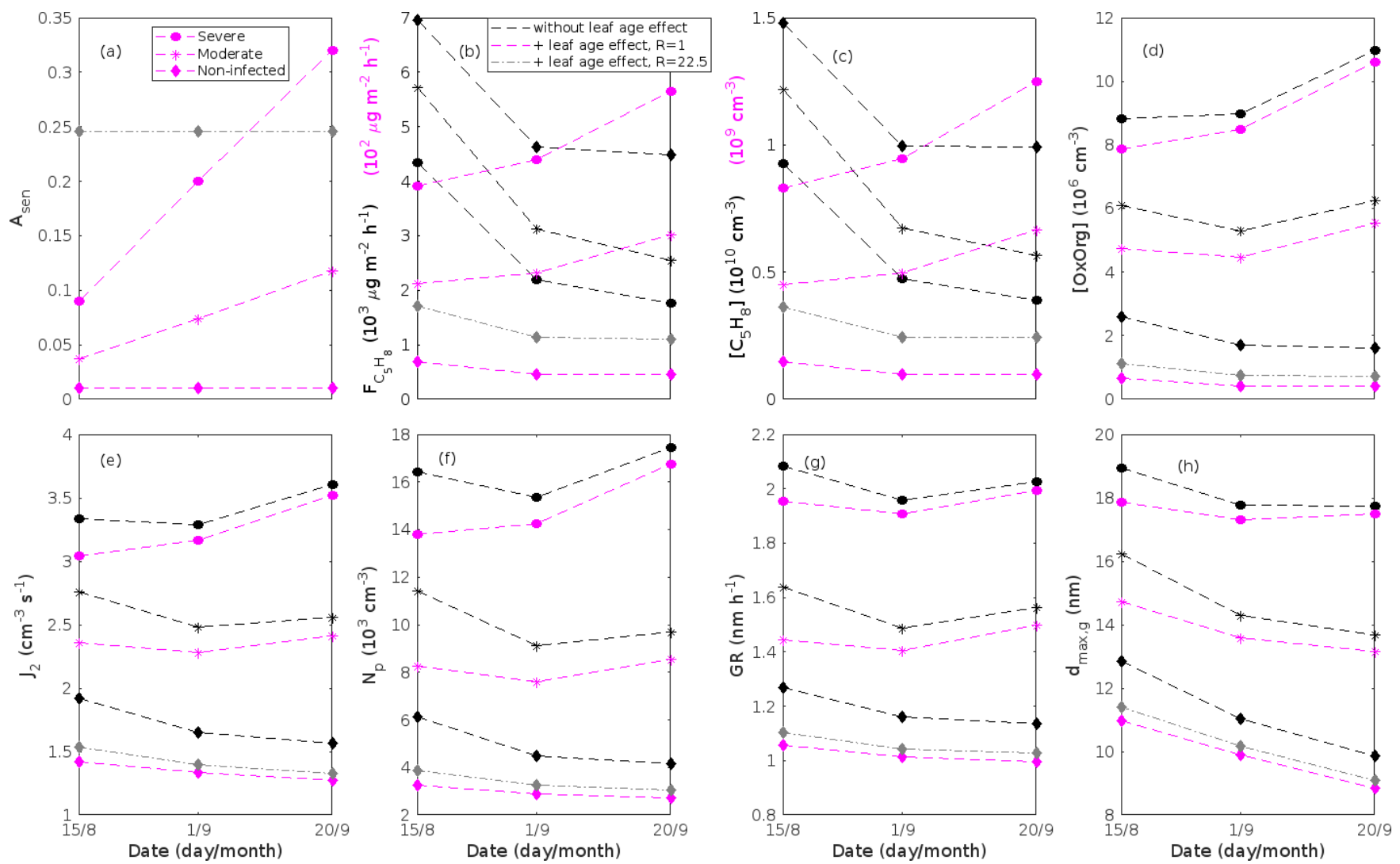

Figure B3. An oak stand infected by oak powdery mildew in comparison to a non-infected oak stand simulated with and without considering the impact of leaf age on the rates of isoprene emissions. (a) The fraction of isoprene emitted in comparison to simulations where the leaf age effect was not considered. For example, in order to reach $R=1$ in simulations of a non-infected stand (magenta diamonds), the leaves are assumed to only emit $1 \%$ of isoprene compared to our default simulations of a non-infected stand (black diamonds in Fig. 7a). The syntax is equivalent to that of Guenther et al. (2012, p. 1476). (b) Canopy emissions of isoprene and atmospheric concentrations of (c) isoprene and (d) OxOrg. The units provided in black in (b)-(c) are connected to black and grey data points, while the units in magenta in (b)-(c) are connected to magenta data points. (e) Formation rate of $2 \mathrm{~nm}$ particles, (f) number concentrations of formed particles, (g) growth rates of newly formed particles, and (h) the daily maxima diameter of the growing particle mode. The values of other parameters during these simulations are the same as in Fig. 7. "Moderately" and "severely" refer to $30 \%$ and $80 \%$ of the leaf area being infected by fungi by the 20th of September, respectively. Black markers are for simulations where the effect of leaf age was not considered (see Fig. 7 for $R$ ), while magenta markers are for simulations where the emission of isoprene was reduced sufficiently for $R$ to be just under 1 . Grey diamonds are used to illustrate simulation results of a non-infected oak stand, where the emission of isoprene has been reduced sufficiently for $R$ to be just under 22.5. Simulation results for severe are always indicated by circles, for moderate by asterisks, and for non-infected by diamonds (independent of whether the effect of leaf age was considered or not). 

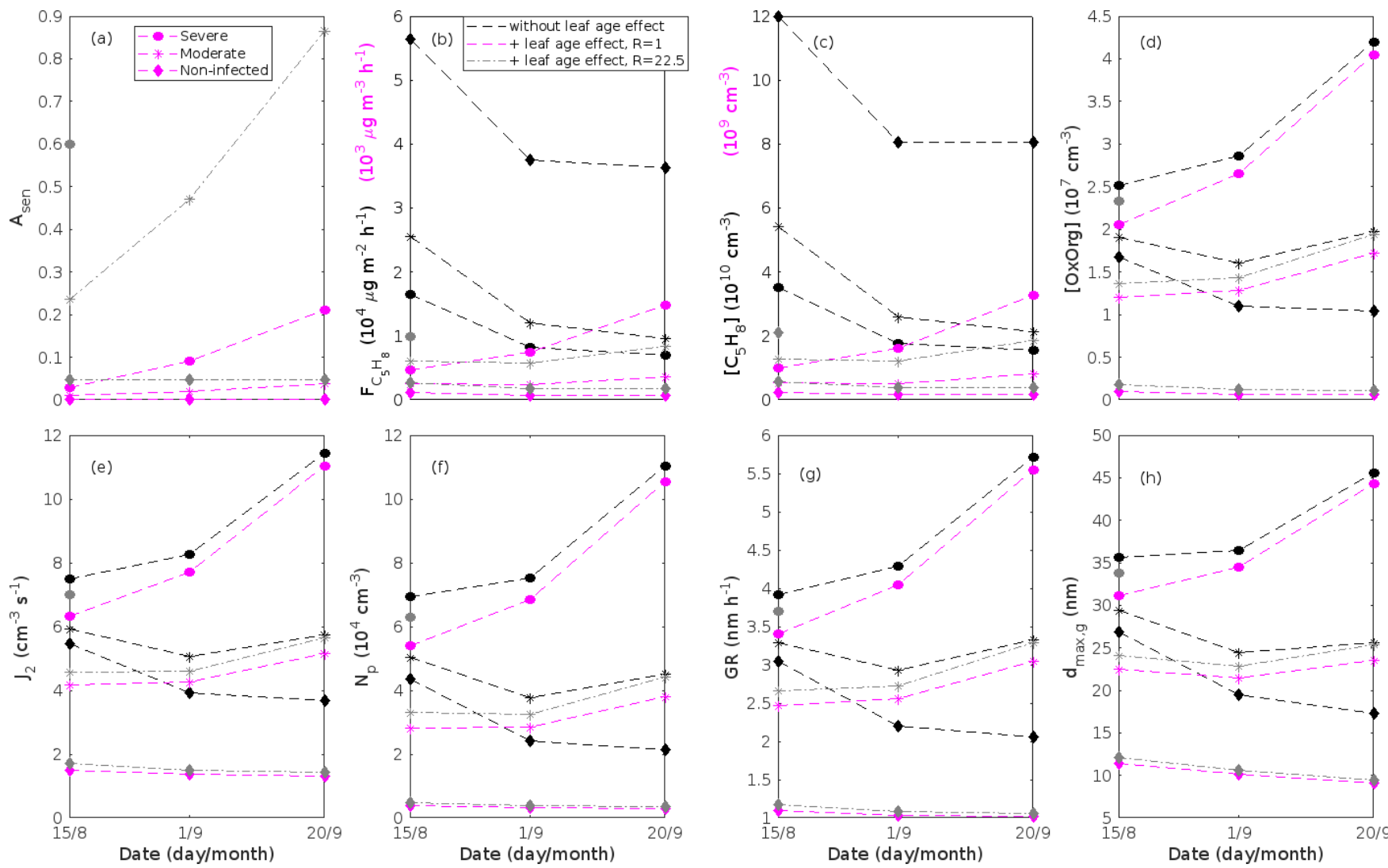

Figure B4. A poplar stand infected by rust in comparison to a non-infected poplar stand simulated with and without considering the impact of leaf age on the rates of isoprene emissions. (a) The fraction of isoprene emitted in comparison to simulations where the leaf age effect was not considered. (b) Canopy emissions of isoprene and atmospheric concentrations of (c) isoprene and (d) OxOrg. The units provided in black in (b) - (c) are connected to black and grey data points, while the units in magenta in (b)-(c) are connected to magenta data points. (e) Formation rate of $2 \mathrm{~nm}$ particles, (f) number concentrations of formed particles, (g) growth rates of newly formed particles, and (h) the daily maxima diameter of the growing particle mode. The values of other parameters during these simulations are the same as in Fig. 8. Grey markers are for simulations where the emission of isoprene was reduced sufficiently for $R$ to be just under 22.5. Symbols are used in the same way as in Fig. B3. 


\section{Appendix C: Chemical reactions in the model}

We considered the following chemical reactions in our model.

$\mathrm{OH}+$ isoprene $\rightarrow$ product $+\gamma \mathrm{OxOrg}_{(\mathrm{g})}$,

$k=2.7 \times 10^{-11} \times e^{(390 / T)} \mathrm{cm}^{3}$ molec $^{-1} \mathrm{~s}^{-1}$,

$\gamma_{\mathrm{a}}=0.03 \%$

$\mathrm{O}_{3}+$ isoprene $\rightarrow$ product $+\gamma \mathrm{OxOrg}_{(\mathrm{g})}$,

$k=1.03 \times 10^{-14} \times e^{(-1995 / T)} \mathrm{cm}^{3}$ molec. ${ }^{-1} \mathrm{~s}^{-1}$,

$\gamma_{\mathrm{b}}=0.01 \%$

$\mathrm{OH}+$ monoterpenes $\rightarrow$ product $+\gamma \mathrm{OxOrg}_{(\mathrm{g})}$,

$k=1.2 \times 10^{-11} \times e^{(440 / T)} \mathrm{cm}^{3}$ molec. ${ }^{-1} \mathrm{~s}^{-1}$,

$\gamma_{\mathrm{c}}=1.7 \%$

$\mathrm{O}_{3}+$ monoterpenes $\rightarrow$ product $+\gamma \mathrm{OxOrg}_{(\mathrm{g})}$,

$k=8.05 \times 10^{-16} \times e^{(-640 / T)} \mathrm{cm}^{3}$ molec. ${ }^{-1} \mathrm{~s}^{-1}$,

$\gamma_{d}=5.0 \%$

$\mathrm{OH}+$ methyl salicylate $\rightarrow$ product $+\gamma \mathrm{OxOrg}_{(\mathrm{g})}$,

$k=4.0 \times 10^{-12} \mathrm{~cm}^{3}$ molec. $^{-1} \mathrm{~s}^{-1}$,

$\gamma_{\mathrm{e}}=10.0 \%$

$\mathrm{OH}+\mathrm{LOX} \rightarrow$ product,

$k=6.0 \times 10^{-11} \mathrm{~cm}^{3}$ molec. ${ }^{-1} \mathrm{~s}^{-1}$

$\mathrm{OH}+$ methanol $\rightarrow$ product,

$k=2.85 \times 10^{-12} \times e^{(-345 / T)} \mathrm{cm}^{3}$ molec $^{-1} \mathrm{~s}^{-1}$

$\mathrm{O}_{3}+$ DMNT, sesquiterpenes or oxidised

sesquiterpenes $\rightarrow$ product $+\gamma \mathrm{OxOrg}_{(\mathrm{g})}$,

$k=1.2 \times 10^{-14} \mathrm{~cm}^{3}$ molec. $^{-1} \mathrm{~s}^{-1}, \gamma_{\mathrm{f}}=7.7 \%$

$\operatorname{OxOrg}_{(\mathrm{g})} \rightarrow \mathrm{OxOrg}_{(\mathrm{p})}, k=\mathrm{CS} \times 0.5$

$\mathrm{OH}+\mathrm{SO}_{2} \rightarrow \mathrm{H}_{2} \mathrm{SO}_{4(\mathrm{~g})}$,

$k=1.5 \times 10^{-12} \mathrm{~cm}^{3}$ molec. $^{-1} \mathrm{~s}^{-1}$

$\mathrm{H}_{2} \mathrm{SO}_{4(\mathrm{~g})} \rightarrow \mathrm{H}_{2} \mathrm{SO}_{4(\mathrm{p})}, k=\mathrm{CS}$

$T$ is temperature (K), $\mathrm{p}$ indicates particle phase, CS is the condensation sink, and $\gamma_{i}$ is the fraction of organic products that can partition to the particle phase (OxOrg). In practice, $\gamma_{i}$ is either reported HOM yields, as defined in Ehn et al. (2014), or reported SOA yields divided by 2.2. SOA yields are decreased by a factor of 2.2 in order to account for the fact that SOA yields represent mass yields and not molar yields (as is the case for HOM yields). We utilised HOM yields based on Jokinen et al. (2015) $\left(\gamma_{\mathrm{a}}, \gamma_{\mathrm{b}}, \gamma_{\mathrm{c}}, \gamma_{\mathrm{d}}\right)$, Berndt et al. (2016) $\left(\gamma_{\mathrm{c}}\right)$, and Ehn et al. (2014) $\left(\gamma_{\mathrm{d}}\right)$. We used SOA yields from Mentel et al. (2013) $\left(\gamma_{\mathrm{e}}, \gamma_{\mathrm{f}}\right)$. 


\section{Appendix D: Sensitivity tests}

Table D1. Constrained parameters for sensitivity tests and their range of values. Nine different sensitivity tests (ST1-9) were conducted for all plant species and infections, and only one parameter was changed at a time between these test. BHL is the planetary boundary layer height, $\mathrm{PPFD}_{\max }$ is the daily maximum photosynthetic photon flux density, $T_{\max }$ is the maximum daily temperature, LAI is the leaf area index of non-infested leaves, CS is the condensation sink, and $\gamma_{\text {OxOrg }}$ is the yield of OxOrg. HPB and SMEAR I refer to simulations conducted under Hohenpeißenberg (i.e. oak and poplar) and SMEAR I (i.e. birch) conditions, respectively.

\begin{tabular}{|c|c|c|c|c|}
\hline $\begin{array}{l}\text { Sensitivity } \\
\text { test no. }\end{array}$ & Parameter that changes & HPB & SMEAR I & Notes and references \\
\hline ST1 & $\mathrm{BLH}(\mathrm{m})$ & \multicolumn{2}{|c|}{$200-2500$} & Classical textbook example. \\
\hline ST2 & $\operatorname{PPFD}_{\max }\left(\mu \mathrm{mol} \mathrm{m}{ }^{-2} \mathrm{~s}^{-1}\right)$ & 200-2000 & $200-1600$ & $\begin{array}{l}\text { The lower limit is based on } \\
\text { observations at the SMEAR I } \\
\text { station, and the upper limit is } \\
\text { based on the theoretical clear } \\
\text { sky maxima. }\end{array}$ \\
\hline ST3 & $T_{\max }\left({ }^{\circ} \mathrm{C}\right)$ & $10-40$ & $5-35$ & $\begin{array}{l}\text { Based on observations and the } \\
\text { IPCC } 2014 \text { predictions of the } \\
\text { regional temperature increase. }\end{array}$ \\
\hline ST4 & $\operatorname{LAI}\left(\mathrm{m}^{2} \mathrm{~m}^{-2}\right)$ & $1-9$ & $0.5-4$ & $\begin{array}{l}\text { The upper limit is based on Tri- } \\
\text { pathi et al. (2016). }\end{array}$ \\
\hline ST5 & {$\left[\mathrm{O}_{3}\right](\mathrm{ppb})$} & $35-100$ & $20-70$ & $\begin{array}{l}\text { Naja et al. (2003), Ruuskanen } \\
\text { et al. (2003). The upper end for } \\
\text { HPB simulations is similar to } \\
\text { the highest values that are ob- } \\
\text { served in the Amazon, where } \\
\text { concentrations of isoprene can } \\
\text { be very high (e.g. Pacifico et al., } \\
\text { 2015) }\end{array}$ \\
\hline ST6 & {$[\mathrm{OH}]_{\max }\left(\right.$ molec. $\left.\mathrm{cm}^{-3}\right)$} & $0.1-10 \times 10^{6}$ & $1-25 \times 10^{5}$ & $\begin{array}{l}\text { Based on Petäjä et al. (2009), } \\
\text { Berresheim et al. (2000), and } \\
\text { Rohrer and Berresheim (2006). } \\
\text { The lower limit has not been } \\
\text { observed in HPB but is included } \\
\text { in order to test the impact of po- } \\
\text { tential OH depletion on our re- } \\
\text { sults. }\end{array}$ \\
\hline ST7 & {$\left[\mathrm{H}_{2} \mathrm{SO}_{4}\right]_{\max }\left(\right.$ molec. $\left.\mathrm{cm}^{-3}\right)$} & $5-25 \times 10^{6}$ & $1-6.5 \times 10^{6}$ & $\begin{array}{l}\text { Birmili et al. (2003), Kyrö et } \\
\text { al. (2014). }\end{array}$ \\
\hline ST8 & $\mathrm{CS}\left(\mathrm{s}^{-1}\right)$ & $2-8 \times 10^{-3}$ & $0.2-3.5 \times 10^{-3}$ & $\begin{array}{l}\text { Birmili et al. (2003), Vana et } \\
\text { al. (2016), Kyrö et al. (2014). }\end{array}$ \\
\hline ST9 & $\gamma_{\mathrm{OxOrg}}$ & $0.1-2 \times$ & xOrg, default & $\begin{array}{l}\text { Ehn et al. (2014), Jokinen et } \\
\text { al. (2015), Bianchi et al. (2019), } \\
\text { McFiggans et al. (2019). }\end{array}$ \\
\hline
\end{tabular}



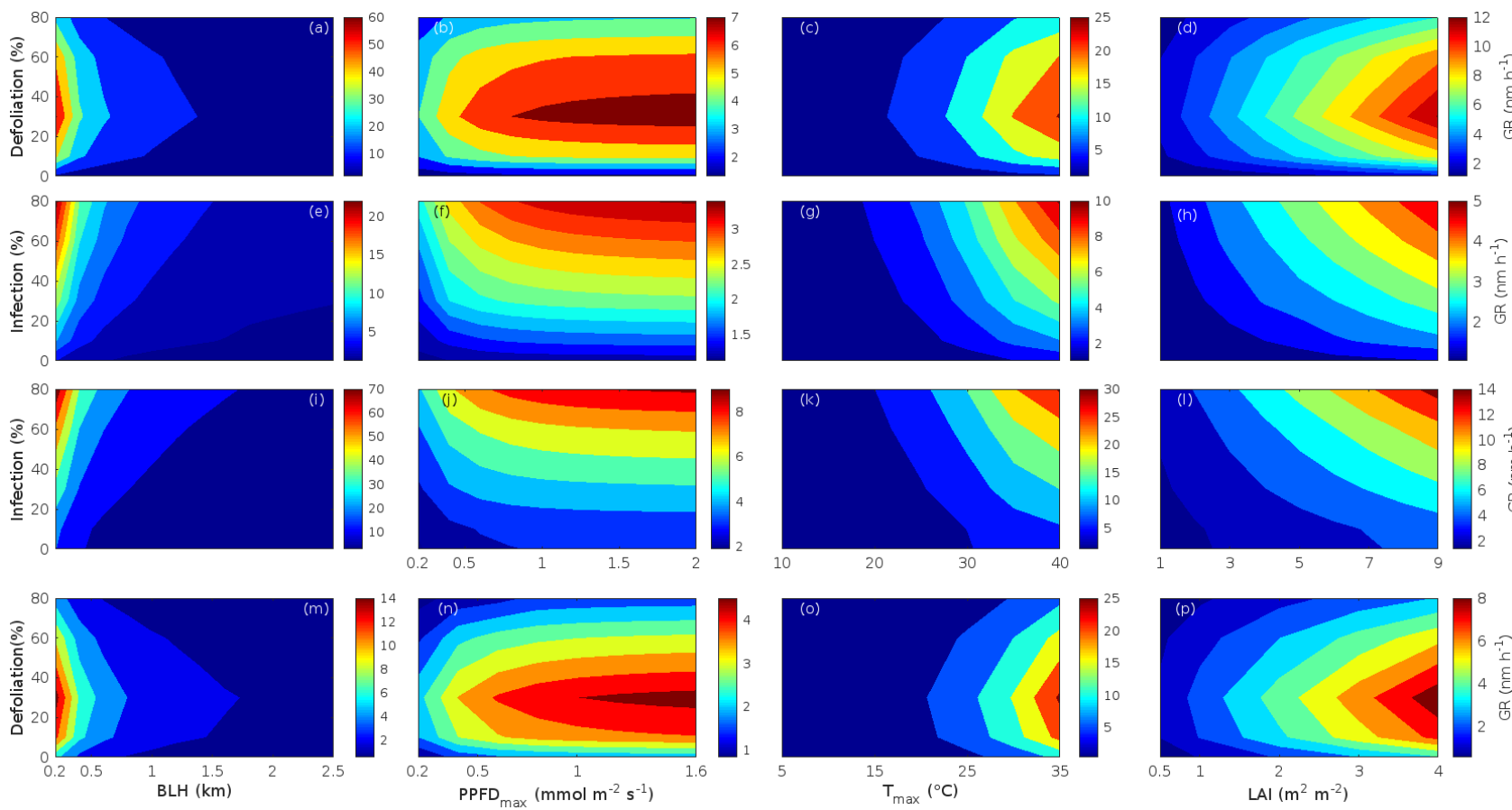

Figure D1. Impact of changed boundary conditions on the growth rate of small particles in non-infected and biotically stressed forest stands. The subplots correspond to those in Fig. 10, but the subplots here display growth rate instead of the number of particles. Thus, we refer the reader to Fig. 10 for further details.
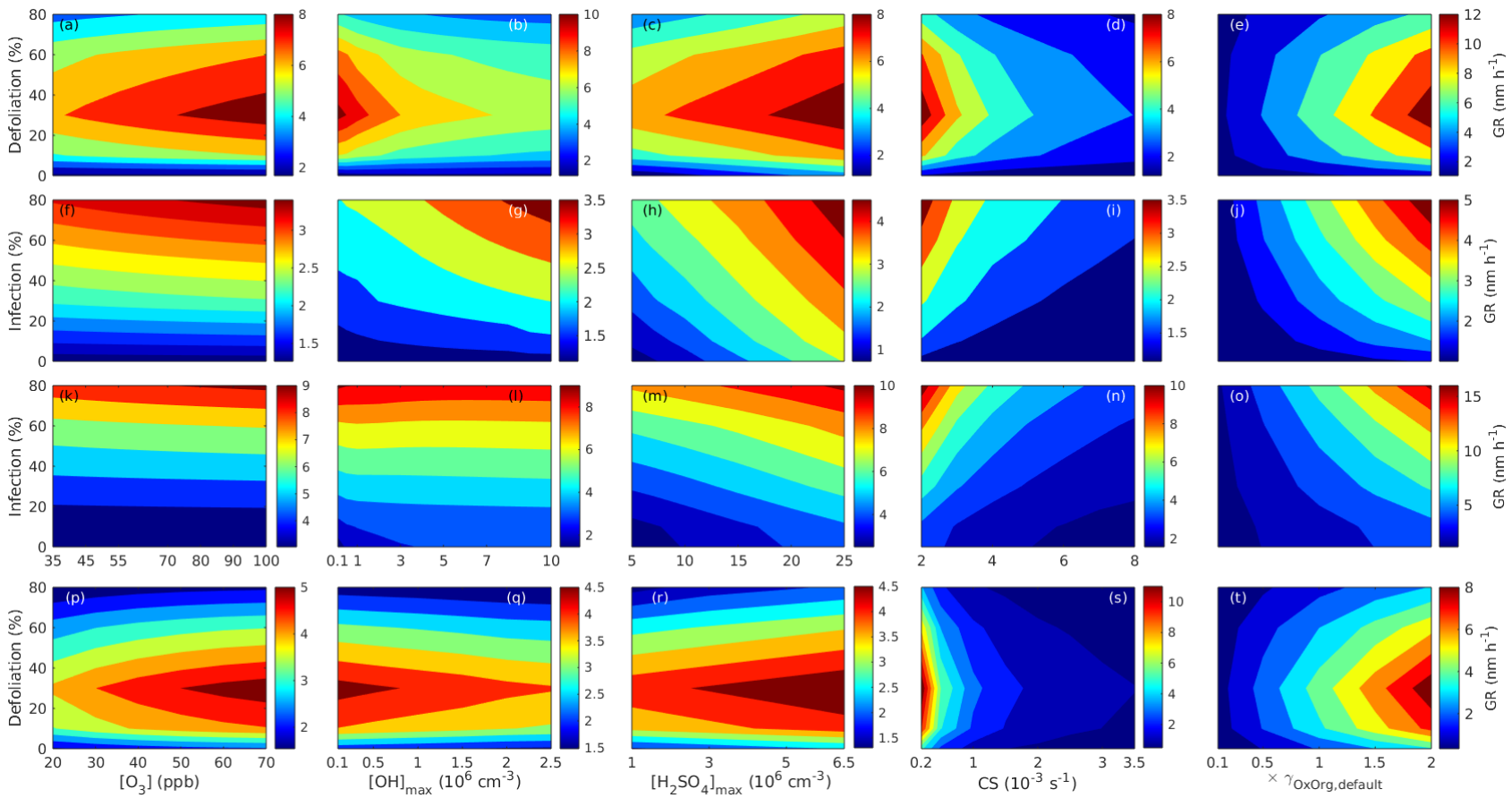

Figure D2. Impact of changed boundary conditions on the growth rate of small particles in non-infected and biotically stressed forest stands. The subplots correspond to those in Fig. 11, but the subplots here display growth rate instead of the number of particles. Thus, we refer the reader to Fig. 11 for further details. 
Data availability. The model code is available upon reasonable request by contacting Ditte Taipale (ditte.taipale@helsinki.fi). SMEAR I mountain birch leafing data can be obtained by contacting Vesa Haataja (vesa.haataja@ helsinki.fi). All other data used to constrain the model are publicly available from the provided references.

Author contributions. The idea and concept for this work was created by ÜN. ÜN standardised the published emission rates. VMK, $\mathrm{MK}$, and ME developed the theory for the aerosol module. DT developed the model code, conducted the simulations, and wrote the manuscript with input from all authors. All authors discussed the results and commented on and edited the manuscript.

Competing interests. The contact author has declared that neither they nor their co-authors have any competing interests.

Disclaimer. Publisher's note: Copernicus Publications remains neutral with regard to jurisdictional claims in published maps and institutional affiliations.

Acknowledgements. Ditte Taipale thanks Pekka Kaitaniemi for the valuable discussions related to autumnal moth simulation set-up and Juho Aalto, Yifan Jiang, and Tero Klemola for the use of photos.

Financial support. This work was supported by the European Regional Development Fund (Centre of Excellence EcolChange), the European Research Council (advanced grant no. 322603, SIP-VOL+), the Academy of Finland Center of Excellence (project no. 307331), and the Academy of Finland Flagship funding (grant no. 337549). Ditte Taipale was also supported by the Academy of Finland (grant no. 307957)

Open-access funding was provided by the Helsinki University Library.

Review statement. This paper was edited by Susannah Burrows and reviewed by Alex B. Guenther and one anonymous referee.

\section{References}

Aalto, J., Kolari, P., Hari, P., Kerminen, V.-M., Schiestl-Aalto, P., Aaltonen, H., Levula, J., Siivola, E., Kulmala, M., and Bäck, J.: New foliage growth is a significant, unaccounted source for volatiles in boreal evergreen forests, Biogeosciences, 11, 13311344, https://doi.org/10.5194/bg-11-1331-2014, 2014.

Aalto, P., Aalto, T., and Keronen, P. SMEAR I Värriö forest meteorology, air quality and soil, Institute for Atmospheric and Earth System Research [data set], available at: http://urn.fi/urn: nbn:fi:att:2a9c28bd-ca13-4a17-8b76-922bafa067a7 (last access: 29 November 2021), 2019.
Åhman, I: Rust scorings in a plantation of Salix viminalis clones during ten consecutive years, Eur. J. For. Path., 28, 251-258, https://doi.org/10.1111/j.1439-0329.1998.tb01180.x, 1998.

Albrecht, B. A.: Aerosols, cloud microphysics, and fractional cloudiness, Science, 245, 1227-1230, https://doi.org/10.1126/science.245.4923.1227, 1989.

Ammunét, T., Klemola, T., and Saikkonen, K.: Impact of host plant quality on geometrid moth expansion on environmental and local population scales, Ecogeg., 34, 848-855, https://doi.org/10.1111/j.1600-0587.2011.06685.x, 2011.

Andreae, M. O., Afchine, A., Albrecht, R., Holanda, B. A., Artaxo, P., Barbosa, H. M. J., Borrmann, S., Cecchini, M. A., Costa, A., Dollner, M., Fütterer, D., Järvinen, E., Jurkat, T., Klimach, T., Konemann, T., Knote, C., Krämer, M., Krisna, T., Machado, L. A. T., Mertes, S., Minikin, A., Pöhlker, C., Pöhlker, M. L., Pöschl, U., Rosenfeld, D., Sauer, D., Schlager, H., Schnaiter, M., Schneider, J., Schulz, C., Spanu, A., Sperling, V. B., Voigt, C., Walser, A., Wang, J., Weinzierl, B., Wendisch, M., and Ziereis, H.: Aerosol characteristics and particle production in the upper troposphere over the Amazon Basin, Atmos. Chem. Phys., 18, 921-961, https://doi.org/10.5194/acp-18-921-2018, 2018.

Aphalo, P. J., Lahti, M., Lehto, T., Repo, T., Rummukainen, A., Mannerkoski, H., and Finér, L.: Responses of silver birch saplings to low soil temperature, Silva Fenn., 40, 429-444, https://doi.org/10.14214/sf.328, 2006.

Arimura, G.-I., Köpke, S., Kunert, M., Volpe, V., David, A., Brand, P., Dabrowska, P., Maffei, M. E., and Boland, W.: Effects of feeding Spodoptera littoralis on lima bean leaves, IV. Diurnal and nocturnal damage differentially initiate plant volatile emission, Plant Physiol., 146, 965-973, https://doi.org/10.1104/pp.107.111088, 2008.

Asmi, E., Kivekäs, N., Kerminen, V.-M., Komppula, M., Hyvärinen, A.-P., Hatakka, J., Viisanen, Y., and Lihavainen, H.: Secondary new particle formation in Northern Finland Pallas site between the years 2000 and 2010, Atmos. Chem. Phys., 11, 12959-12972, https://doi.org/10.5194/acp-11-12959-2011, 2011.

Atkinson, R. and Arey, J.: Atmospheric degradation of volatile organic compounds, Chem. Rev., 103, 4605-4638, https://doi.org/10.1021/cr0206420, 2003.

Atkinson, R., Aschmann, S. M, Arey, J., and Shorees, B.: Formation of $\mathrm{OH}$ radicals in the gas phase reactions of $\mathrm{O}_{3}$ with a series of terpenes, J. Geophys. Res. A, 97, 6065-6073, https://doi.org/10.1029/92JD00062, 1992.

Ayres, M. P. and MacLean, Jr. S. F.: Molt as a component of insect development: Galerucella sagittariae (Chrysomelidae) and Epirrita autumnata (Geometridae), Oikos, 48, 273-279, https://doi.org/10.2307/3565514, 1987.

Bale, J. S., Masters, G. J., Hodkinson, I. D., Awmack, C., Bezemer, T. M., Brown, V. K., Butterfield, J., Buse, A., Coulson, J. C., Farrar, J., Good, J. E. G., Harrington, R., Hartley, S., Jones, T. H., Lindroth, R. L., Press, M. C., Symrnioudis, I., Watt, A. D., and Whittaker, J. B.: Herbivory in global climate change research: direct effects of rising temperature on insect herbivores, Glob. Change Biol., 8, 1-16, https://doi.org/10.1046/j.13652486.2002.00451.x, 2002.

Berg, A. R., Heald, C. L., Huff Hartz, K. E., Hallar, A. G., Meddens, A. J. H., Hicke, J. A., Lamarque, J.-F., and Tilmes, S.: The impact of bark beetle infestations on monoterpene emissions and secondary organic aerosol formation in western North America, At- 
mos. Chem. Phys., 13, 3149-3161, https://doi.org/10.5194/acp13-3149-2013, 2013.

Bergström, R., Hallquist, M., Simpson, D., Wildt, J., and Mentel, T. F.: Biotic stress: a significant contributor to organic aerosol in Europe?, Atmos. Chem. Phys., 14, 13643-13660, https://doi.org/10.5194/acp-14-13643-2014, 2014.

Berndt, T., Richters, S., Jokinen, T., Hyttinen, N., Kurtén, T., Otkjær, R. V., Kjaergaard, H. G., Stratmann, F., Herrmann, H., Sipilä, M., Kulmala, M., and Ehn, M.: Hydroxyl radical-induced formation of highly oxidized organic compounds, Nat. Commun., 7, 13677, https://doi.org/10.1038/ncomms13677, 2016.

Berresheim, H., Elste, T., Plass-Dülmer, C., Eisele, F. L., and Tanner, D. J.: Chemical ionization mass spectrometer for longterm measurements of atmospheric $\mathrm{OH}$ and $\mathrm{H} 2 \mathrm{SO} 4$, Int. J. Mass. Spectrom., 202, 91-109, https://doi.org/10.1016/S13873806(00)00233-5, 2000.

Bert, D., Lasnier, J.-B., Capdevielle, X., Dugravot, A., and Desprez-Loustau, M.-L.: Powdery mildew decreases the radial growth of oak trees with cumulative and delayed effects over years, PLoS ONE, 11, e0155344, https://doi.org/10.1371/journal.pone.0155344, 2016.

Bianchi, F., Kurtén, T., Riva, M., Mohr, C., Rissanen, M. P., Roldin, P., Berndt, T., Crounse, J. D., Wennberg, P. O., Mentel, T. F., Wildt, J., Junninen, H., Jokinen, T., Kulmala, M., Worsnop, D. R., Thronton, J. A., Donahue, N., Kjaergaard, H. G., and Ehn, M.: Highly oxygenated organic molecules (HOM) from gas-phase autoxidation involving peroxy radicals: A key contributor to atmospheric aerosol, Chem. Rev., 119, 3472-3509, https://doi.org/10.1021/acs.chemrev.8b00395, 2019.

Bilde, M., Barsanti, K., Booth, M. D., Cappa, C. D., Donahue, N. M., McFiggans, G., Krieger, U. K., Marcolli, C., Topping, D., Ziemann, P., Barley, M., Clegg, S., Dennis-Smither, B., Emanuelsson, E. U., Hallquist, M., Hallquist, A. M., Khlystov, A., Kulmala, M., Mogensen, D., Percival, C. P., Pope, F., Reid, J. R., Ribeiro da Silva, M. A. V., Rosenoern, T., Salo, K., Soonsin, V. P., Yli-Juuti, T., Prisle, N. L., Pagels, J., Rarey, J., Zardini, A. A., and Riipinen, I.: Saturation vapor pressures and transition enthalpies of low-volatility organic molecules of atmospheric relevance: from dicarboxylic acids to complex mixtures, Chem. Rev., 115, 3679-4570, https://doi.org/10.1021/cr5005502, 2015.

Birmili, W., Berresheim, H., Plass-Dülmer, C., Elste, T., Gilge, S., Wiedensohler, A., and Uhrner, U.: The Hohenpeissenberg aerosol formation experiment (HAFEX): a long-term study including size-resolved aerosol, $\mathrm{H} 2 \mathrm{SO} 4, \mathrm{OH}$, and monoterpenes measurements, Atmos. Chem. Phys., 3, 361-376, https://doi.org/10.5194/acp-3-361-2003, 2003.

Blande, J. D., Tiiva, P., Oksanen, E., and Holopainen, J. K.: Emission of herbivore-induced volatile terpenoids from two hybrid aspen (Populus tremula $\times$ tremuloides) clones under ambient and elevated ozone concentrations in the field, Glob. Change Biol., 13, 2538-2550, https://doi.org/10.1111/j.13652486.2007.01453.x, 2007.

Blande, J. D., Turunen, K., and Holopainen, J. K.: Pine weevil feeding on Norway spruce bark has a stronger impact on needle VOC emissions than enhanced ultraviolet-B radiation, Environ. Pollut., 157, 174-180, https://doi.org/10.1016/j.envpol.2008.07.007, 2009.

Boy, M., Kulmala, M., Ruuskanen, T. M., Pihlatie, M., Reissell, A., Aalto, P. P., Keronen, P., Dal Maso, M., Hellen, H., Hakola,
H., Jansson, R., Hanke, M., and Arnold, F.: Sulphuric acid closure and contribution to nucleation mode particle growth, Atmos. Chem. Phys., 5, 863-878, https://doi.org/10.5194/acp-5863-2005, 2005.

Boyd, I. L., Freer-Smith, P. H., Gilligan, C. A., and Godfray, H. C. J: The consequence of tree pests and diseases for ecosystem services, Science, 342, 1235773, https://doi.org/10.1126/science.1235773, 2013.

Brilli, F., Ciccioli, P., Frattoni, M., Prestininzi, M., Spanedda, A. F., and Loreto, F.: Constitutive and herbivore-induced monoterpenes emitted by Populus $\times$ euroamericana leaves are key volatiles that orient Chrysomela populi beetles, Plant Cell Environ., 32, 542552, https://doi.org/10.1111/j.1365-3040.2009.01948.x, 2009.

Bylund, H.: Long-term interactions between the autumnal moth and mountain birch: The roles of resources, competitors, natural enemies, and weather (PhD Thesis), Swedish University Agricultural Sciences, Uppsala, Sweden, 1995.

Cannon, R. J. C.: The implications of predicted climate change for insect pests in the UK, with emphasis on non-indigenous species, Glob. Change Biol., 4, 785-796, https://doi.org/10.1046/j.13652486.1998.00190.x, 1998.

Calvert, J., Atkinson, R., Kerr, J. A., Madronich, S., Moortgat, G. K., Wallington, T. J., and Yarwood, G.: The Mechanisms of Atmospheric Oxidation of the Alkenes, Oxford University Press, Oxford, UK, 2000.

Coleman, T. W., Haavik, L. J., Foelker, C., and Liebhold, A. M.: Forest Insect \& Disease Leaflet 162 April 2020, US Forest Service, 2020.

Copolovici, L., Väärtnõu, F., Portillo Estrada, M., and Niinemets, Ü.: Oak powdery mildew (Erysiphe alphitoides)induced volatile emissions scale with the degree of infection in Quercus robur, Tree Physiol., 34, 1399-1410, https://doi.org/10.1093/treephys/tpu091, 2014.

Copolovici, L., Pag, A., Kännaste, A., Bodescu, A., Tomescu, D., Copolovici, D., Soran, M.-L., and Niinemets, Ü.: Disproportionate photosynthetic decline and inverse relationship between constitutive and induced volatile emissions upon feeding of Quercus robur leaves by large larvae of gypsy moth (Lymantria dispar), Environ. Exp. Bot., 138, 184-192, https://doi.org/10.1016/j.envexpbot.2017.03.014, 2017.

Covarelli, L., Beccari, G., Tosi, L., Fabre, B., and Frey, P.: Threeyear investigations on leaf rust of poplar cultivated for biomass production in Umbria, Central Italy, Biomass Bioenerg., 49, 315322, https://doi.org/10.1016/j.biombioe.2012.12.032, 2013.

Dahlberg, U., Berge, T. W., Petersson, H., and Vencatasawmy, C. P.: Modelling biomass and leaf area index in a sub-arctic Scandinavian mountain area, Scand. J. Forest Res., 19, 60-71, https://doi.org/10.1080/02827580310019266, 2004.

Dal Maso, M., Sogacheva, L., Aalto, P. P., Riipinen, I., Komppula, M., Tunved, P., Korhonen, L., Suur-Uski, V., Hirsikko, A., Kurtén, T., Kerminen, V.-M., Lihavainen, H., Viisanen, Y., Hansson, H.-C., and Kulmala, M.: Aerosol size distribution measurements at four Nordic field stations: identification, analysis and trajectory analysis of new particle formation bursts, Tellus B, 59, 350-361, https://doi.org/10.1111/j.1600-0889.2007.00267.x, 2007.

Dal Maso, M., Hyvärinen, A., Komppula, M., Tunved, P., Kerminen, V.-M., Lihavainen, H., Viisanen, Y., Hansson, H.-C., and Kulmala, M.: Annual and interannual variation in boreal 
forest aerosol particle number and volume concentration and their connection to particle formation, Tellus B, 60, 495-508, https://doi.org/10.1111/j.1600-0889.2008.00366.x, 2008.

Desprez-Loustau, M. L., Feau, N., Mougou-Hamdane, A., and Dutech, C.: Interspecific and intraspecific diversity in oak powdery mildews in Europe: coevolution history and adaptation to their hosts, Mycoscience, 52, 165-173, https://doi.org/10.1007/s10267-010-0100-5, 2011.

Di Carlo, P., Brune, W. H., Martinez, M., Harder, H., Lesher, R., Ren, X., Thornberry, T., Carroll, M. A., Young, V., Shepson, P. B., Riemer, D., Apel, E., and Campbell, C.: Missing $\mathrm{OH}$ reactivity in a forest: Evidence for unknown reactive biogenic VOCs, Science, 304, 722-725, https://doi.org/10.1126/science.1094392, 2004.

Donahue, N. M., Ortega, I. K., Chuang, W., Riipinen, I., Riccobono, F., Schobesberger, S., Dommen, J., Baltensperger, U., Kulmala, M., Worsnop, D. R., and Vehkamäki, H.: How do organic vapors contribute to new-particle formation?, Faraday Discuss., 165, 91-104, https://doi.org/10.1039/C3FD00046J, 2013.

Douma, J. C., Ganzeveld, L. N., Unsicker, S. B., Boeckler, A., and Dicke, M.: What makes a volatile organic compound a reliable indicator of insect herbivory?, Plant Cell Environ., 42, 33083325, https://doi.org/10.1111/pce.13624, 2019.

Dunne, E. M., Gordon, H., Kürten, A., Almeida, J., Duplissy, J., Williamson, C., Ortega, I. K., Pringle, K. J., Adamov, A., Baltensperger, U., Barmet, P., Benduhn, F., Bianchi, F., Breitenlechner, M., Clarke, A., Curtius, J., Dommen, J., Donahue, N. M., Ehrhart, S., Flagan, R. C., Franchin, A., Guida, R., Hakala, J., Hansel, A., Heinritzi, M., Jokinen, T., Kangasluoma, J., Kirkby, J., Kulmala, M., Kupic, A., Lawler, M. J., Lehtipalo, K., Makhmutov, V., Mann, G., Mathot, S., Merikanto, J., Miettinen, P., Nenes, A., Onnela, A., Rap, A., Reddington, C. L. S., Riccobono, F., Richards, N. A. D., Rissanen, M. P., Rondo, L., Sarnela, N., Schobesberger, S., Sengupta, K., Simon, M., Sipilä, M., Smith, J. N., Stozkhov, Y., Tomé, A., Tröstl, J., Wagner, P. E., Wimmer, D., Winkler, P. M., Worsnop, D. R., and Carslaw, K. S.: Global atmospheric particle formation from CERN CLOUD measurements, Science, 354, 1119-1124, https://doi.org/10.1126/science.aaf2649, 2016.

Ehn, M., Kleist, E., Junninen, H., Petäjä, T., Lönn, G., Schobesberger, S., Dal Maso, M., Trimborn, A., Kulmala, M., Worsnop, D. R., Wahner, A., Wildt, J., and Mentel, Th. F.: Gas phase formation of extremely oxidized pinene reaction products in chamber and ambient air, Atmos. Chem. Phys., 12, 5113-5127, https://doi.org/10.5194/acp-12-5113-2012, 2012.

Ehn, M., Thornton, J. A., Kleist, E., Sipilä, M., Junninen, H., Pullinen, I., Springer, M., Rubach, F., Tillmann, R., Lee, B., Lopez-Hilfiker, F., Andres, S., Acir, I-H., Rissanen, M., Jokinen, T., Schobesberger, S., Kangasluoma, J., Kontkanen, J., Nieminen, T., Kurtén, T., Nielsen, L. B., Jørgensen, S., Kjaergaard, H. G., Canagaratna, M., Maso, M. D., Berndt, T., Petäjä, T., Wahner, A., Kerminen, V.-M., Kulmala, M., Worsnop, D. R., Wildt, J., and Mentel, T. F.: A large source of lowvolatility secondary organic aerosol, Nature, 506, 476-479, https://doi.org/10.1038/nature13032, 2014.

El-Ghany, T. M. A., Eman, M. E., and EI-Sheikh, H. H.: Efficacy of fungal rust disease on willow plant in Egypt, Aust. J. Basic Appl. Sci., 3, 1527-1539, 2009.
Faiola, C. and Taipale, D.: Impact of insect herbivory on plant stress volatile emissions from trees: A synthesis of quantitative measurements and recommendations for future research, Atmos. Environ. X, 5, 100060, https://doi.org/10.1016/j.aeaoa.2019.100060, 2020.

Faiola, C. L., Buchholz, A., Kari, E., Yli-Pirilä, P., Holopainen, J. K., Kivimäenpää, M., Miettinen, P., Worsnop, D. R., Lehtinen, K. E. J., Guenther, A. B., and Virtanen, A.: Terpene composition complexity controls secondary organic aerosol yields from Scots pine volatile emissions, Sci. Rep., 8, 3053, https://doi.org/10.1038/s41598-018-21045-1, 2018.

Faiola, C. L., Pullinen, I., Buchholz, A., Khalaj, F., Ylisirniö, A., Kari, E., Miettinen, P., Holopainen, J. K., Kivimäenpää, M., Schobesberger, S., Yli-Juuti, T., and Virtanen, A.: Secondary Organic aerosol formation from healthy and aphid-stressed Scots pine emissions, ACS Earth Space Chem., 3, 1756-1772, https://doi.org/10.1021/acsearthspacechem.9b00118, 2019.

Fiedler, V., Dal Maso, M., Boy, M., Aufmhoff, H., Hoffmann, J., Schuck, T., Birmili, W., Hanke, M., Uecker, J., Arnold, F., and Kulmala, M.: The contribution of sulphuric acid to atmospheric particle formation and growth: a comparison between boundary layers in Northern and Central Europe, Atmos. Chem. Phys., 5, 1773-1785, https://doi.org/10.5194/acp-5-1773-2005, 2005.

Gérard, P. R., Husson, C., Pinon, J., and Frey, P.: Comparison of genetic and virulence diversity of Melampsora laricipopulina populations on wild and cultivated poplar and influence of the alternate host, Phytopathology, 96, 1027-1036, https://doi.org/10.1094/PHYTO-96-1027, 2006.

Ghimire, R. P., Kivimäenpää, M., Kasurinen, A., Häikiö, E., Holopainen, T., and Holopainen, J. K.: Herbivoreinduced BVOC emissions of Scots pine under warming, elevated ozone and increased nitrogen availability in an open-field exposure, Agr. Forest Meteorol., 242, 21-32, https://doi.org/10.1016/j.agrformet.2017.04.008, 2017.

Ghirardo, A., Koch, K., Taipale, R., Zimmer, I., Schnitzler, J.-P., and Rinne, J.: Determination of de novo and pool emissions of terpenes from four common boreal/alpine trees by ${ }^{13} \mathrm{CO}_{2}$ labelling and PTR-MS analysis, Plant Cell Environ., 33, 781-792, https://doi.org/10.1111/j.1365-3040.2009.02104.x, 2010.

Gill, A. L., Gallinat, A. S., Sanders-DeMott, R., Rigden, A. J., Short Gianotti, D. J., Mantooth, J. A., and Templer, P. H.: Changes in autumn senescence in northern hemisphere deciduous trees: a meta-analysis of autumn phenology studies, Ann. Bot., 116, 875-888, https://doi.org/10.1093/aob/mcv055, 2015.

Glawe, D. A.: The powdery mildews: a review of the world's most familiar (yet poorly known) plant pathogens, Annu. Rev. Phytopathol., 46, 27-51, https://doi.org/10.1146/annurev.phyto.46.081407.104740, 2008.

Goldstein, A., Goulden, M., Munger, J. W., Wofsy, S., and Geron, C.: Seasonal course of isoprene emissions from a midlatitude forest, J. Geophys. Res., 103, 31045-31056, https://doi.org/10.1029/98JD02708, 1998.

Größ, J., Hamed, A., Sonntag, A., Spindler, G., Manninen, H. E., Nieminen, T., Kulmala, M., Hõrrak, U., Plass-Dülmer, C., Wiedensohler, A., and Birmili, W.: Atmospheric new particle formation at the research station Melpitz, Germany: connection with gaseous precursors and meteorological parameters, At- 
mos. Chem. Phys., 18, 1835-1861, https://doi.org/10.5194/acp18-1835-2018, 2018.

Grote, R., Monson, R. K., and Niinemets, Ü.: Leaf-level models of constitutive and stress-driven volatile organic compound emissions, Biology, Controls and Models of Tree Volatile Organic Compound Emissions, Tree Physiology, Springer, Dordrecht, 315-355, https://doi.org/10.1007/978-94-007-6606-8_12, 2013.

Grote, R., Sharma, M., Ghirardo, A., Schnitzler, J.-P.: A new modeling approach for estimating abiotic and biotic stressinduced de novo emissions of biogenic volatile organic compounds from plants, Front. Forest Glob. Change, 2, 26, https://doi.org/10.3389/ffgc.2019.00026, 2019.

Gryspeerdt, E., Stier, P., and Partridge, D. G.: Satellite observations of cloud regime development: the role of aerosol processes, Atmos. Chem. Phys., 14, 1141-1158, https://doi.org/10.5194/acp14-1141-2014, 2014.

Guenther, A.: Seasonal and spatial variations in natural volatile organic compound emissions, Ecol. Appl., $\quad 7, \quad 34-45, \quad$ https://doi.org/10.1890/10510761(1997)007[0034:SASVIN]2.0.CO;2, 1997.

Guenther, A., Zimmerman, P., and Wildermuth, M.: Natural volatile organic compound emission rate estimates for U.S. woodland landscapes, Atmos. Environ., 28, 1197-1210, https://doi.org/10.1016/1352-2310(94)90297-6, 1994.

Guenther, A., Karl, T., Harley, P., Wiedinmyer, C., Palmer, P. I., and Geron, C.: Estimates of global terrestrial isoprene emissions using MEGAN (Model of Emissions of Gases and Aerosols from Nature), Atmos. Chem. Phys., 6, 3181-3210, https://doi.org/10.5194/acp-6-3181-2006, 2006.

Guenther, A. B., Monson, R. K., and Fall, R.: Isoprene and monoterpene emission rate variability: Observations with eucalyptus and emission rate algorithm development, J. Geophys. Res., 96, 10799-10808, https://doi.org/10.1029/91JD00960, 1991.

Guenther, A. B., Jiang, X., Heald, C. L., Sakulyanontvittaya, T., Duhl, T., Emmons, L. K., and Wang, X.: The Model of Emissions of Gases and Aerosols from Nature version 2.1 (MEGAN2.1): an extended and updated framework for modeling biogenic emissions, Geosci. Model Dev., 5, 1471-1492, https://doi.org/10.5194/gmd-5-1471-2012, 2012.

Hajji, M., Dreyer, M., and Marçais, B.: Impact of Erysiphe alphitoides on transpiration and photosynthesis in Quercus robur leaves, Eur. J. Plant. Pathol., 125, 63-72, https://doi.org/10.1007/s10658-009-9458-7, 2009.

Häkkinen, S. A. K., Manninen, H. E., Yli-Juuti, T., Merikanto, J., Kajos, M. K., Nieminen, T., D’Andrea, S. D., Asmi, A., Pierce, J. R., Kulmala, M., and Riipinen, I.: Semi-empirical parameterization of size-dependent atmospheric nanoparticle growth in continental environments, Atmos. Chem. Phys., 13, 7665-7682, https://doi.org/10.5194/acp-13-7665-2013, 2013.

Hakola, H., Arey, J., Aschmann, S. M., and Atkinson, R.: Product formation from the gas phase reactions of $\mathrm{OH}$ radicals and $\mathrm{O}_{3}$ with a series of monoterpenes, J. Atmos. Chem., 18, 75-102, https://doi.org/10.1007/BF00694375, 1994.

Hari, P., Kulmala, M., Pohja, T., Lahti, T., Siivola, R., Palva, L., Aalto, P., Hämeri, K., Vesala, T., Luoma, S., and Pulliainen, E.: Air pollution in eastern Lapland: challenge for an environmental measurement station, Silva Fenn., 28, 29-39, https://doi.org/10.14214/sf.a9160, 1994.
Harrington, R., Clark, S. J., Welham, S. J., Verrier, P. J., Denholm, C. H., Hullé, M., Maurice, D., Rounsevell, M. D., and Cocu, N.: Environmental change and the phenology of European aphids, Glob. Change Biol., 13, 1550-1564, https://doi.org/10.1111/j.1365-2486.2007.01394.x, 2007.

Haukioja, E., Neuvonen, S., Hanhimäki, S., and Niemelä, P.: The autumnal moth in Fennoscandia. In: Dynamics of forest insect populations, Springer, Boston, MA, 163-178, 1988.

Heinritzi, M., Dada, L., Simon, M., Stolzenburg, D., Wagner, A. C., Fischer, L., Ahonen, L. R., Amanatidis, S., Baalbaki, R., Baccarini, A., Bauer, P. S., Baumgartner, B., Bianchi, F., Brilke, S., Chen, D., Chiu, R., Dias, A., Dommen, J., Duplissy, J., Finkenzeller, H., Frege, C., Fuchs, C., Garmash, O., Gordon, H., Granzin, M., El Haddad, I., He, X., Helm, J., Hofbauer, V., Hoyle, C. R., Kangasluoma, J., Keber, T., Kim, C., Kürten, A., Lamkaddam, H., Laurila, T. M., Lampilahti, J., Lee, C. P., Lehtipalo, K., Leiminger, M., Mai, H., Makhmutov, V., Manninen, H. E., Marten, R., Mathot, S., Mauldin, R. L., Mentler, B., Molteni, U., Müller, T., Nie, W., Nieminen, T., Onnela, A., Partoll, E., Passananti, M., Petäjä, T., Pfeifer, J., Pospisilova, V., Quéléver, L. L. J., Rissanen, M. P., Rose, C., Schobesberger, S., Scholz, W., Scholze, K., Sipilä, M., Steiner, G., Stozhkov, Y., Tauber, C., Tham, Y. J., Vazquez-Pufleau, M., Virtanen, A., Vogel, A. L., Volkamer, R., Wagner, R., Wang, M., Weitz, L., Wimmer, D., Xiao, M., Yan, C., Ye, P., Zha, Q., Zhou, X., Amorim, A., Baltensperger, U., Hansel, A., Kulmala, M., Tomé, A., Winkler, P. M., Worsnop, D. R., Donahue, N. M., Kirkby, J., and Curtius, J.: Molecular understanding of the suppression of new-particle formation by isoprene, Atmos. Chem. Phys., 20, 11809-11821, https://doi.org/10.5194/acp-20-11809-2020, 2020.

Heiskanen, J.: Estimating aboveground tree biomass and leaf area index in a mountain birch forest using ASTER satellite data, Int. J. Remote Sens., 6, 1135-1158, https://doi.org/10.1080/01431160500353858, 2006.

Hirsikko, A., Laakso, L., Hõrrak, U., Aalto, P. P., Kerminen, V.M., and Kulmala, M.: Annual and size dependent variation of growth rates and ion concentrations in boreal forest, Boreal Environ. Res., 10, 357-369, 2005.

Holopainen, J. K. and Gershenzon, J.: Multiple stress factors and the emission of plant VOCs, Trends Plant Sci. Special Issue: Induc. Biog. Volatile Org. Compd. Plant, 15, 176-184, https://doi.org/10.1016/j.tplants.2010.01.006, 2010.

Hunter, M. D., Kozlov, M. V., Itämies, J., Pulliainen, E., Bäck, J., Kyrö, E. M., and Niemelä, P.: Current temporal trends in moth abundance are counter to predicted effects of climate change in an assemblage of subarctic forest moths, Glob. Change Biol., 20, 1723-1737, https://doi.org/10.1111/gcb.12529, 2014.

Hyvönen, S., Junninen, H., Laakso, L., Dal Maso, M., Grönholm, T., Bonn, B., Keronen, P., Aalto, P., Hiltunen, V., Pohja, T., Launiainen, S., Hari, P., Mannila, H., and Kulmala, M.: A look at aerosol formation using data mining techniques, Atmos. Chem. Phys., 5, 3345-3356, https://doi.org/10.5194/acp-5-3345-2005, 2005.

ICP Forests (Forest Condition in Europe): The 2020 Assessment, ICP Forests Technical Report under the UNECE Convention on Long-range Transboundary Air Pollution (Air Convention), available at: https://www.icp-forests.org/pdf/ICPForests_ TR2020.pdf (last access: 29 November 2021), 2020. 
IPCC: Climate Change 2013: the physical science basis, in: Contribution of Working Group I to the Fifth Assessment Report of the Intergovernmental Panel on Climate Change, edited by: Stocker, T. F., Qin, D., Plattner, G.-K., Tignor, M., Allen, S. K., Boschung, J., Nauels, A., Xia, Y., Bex, V., and Midgley, P. M., Cambridge: Cambridge University Press, 1535 pp., 2013.

Jenkin, M. E. and Clemitshaw, K. C.: Ozone and other secondary photochemical pollutants: chemical processes governing their formation in the planetary boundary layer, Atmos. Environ., 34, 2499-2527, 2000.

Jenkin, M. E., Young, J. C., and Rickard, A. R.: The MCM v3.3.1 degradation scheme for isoprene, Atmos. Chem. Phys., 15, 11433-11459, https://doi.org/10.5194/acp-15-11433-2015, 2015.

Jiang, Y., Ye, J., Veromann, L.-L., and Niinemets, Ü.: Scaling of photosynthesis and constitutive and induced volatile emissions with severity of leaf infection by rust fungus (Melampsora laricipopulina) in Populus balsamifera var. suaveolens, Tree Physiol., 36, 856-872, https://doi.org/10.1093/treephys/tpw035, 2016.

Jimenez, J. L., Canagaratna, M. R., Donahue, N. M., Prevot, A. S., Zhang, Q., Kroll, J. H., DeCarlo, P. F., Allan, J. D., Coe, H., Ng, N. L., Aiken, A. C., Docherty, K. S., Ulbrich, I. M., Grieshop, A. P., Robinson, A. L., Duplissy, J., Smith, J. D., Wilson, K. R., Lanz, V. A., Hueglin, C., Sun, Y. L., Tian, J., Laaksonen, A., Raatikainen, T., Rautiainen, J., Vaattovaara, P., Ehn, M., Kulmala, M., Tomlinson, J. M., Collins, D. R., Cubison, M. J., Dunlea, E. J., Huffman, J. A., Onasch, T. B., Alfarra, M. R., Williams, P. I., Bower, K., Kondo, Y., Schneider, J., Drewnick, F., Borrmann, S., Weimer, S., Demerjian, K., Salcedo, D., Cottrell, L., Griffin, R., Takami, A., Miyoshi, T., Hatakeyama, S., Shimono, A., Sun, J. Y., Zhang, Y. M., Dzepina, K., Kimmel, J. R., Sueper, D., Jayne, J. T., Herndon, S. C., Trimborn, A. M., Williams, L. R., Wood, E. C., Middlebrook, A. M., Kolb, C. E., Baltensperger, U., Worsnop, D. R.: Evolution of organic aerosols in the atmosphere, Science, 326, 1525-1529, https://doi.org/10.1126/science.1180353, 2009.

Johnson, D. M., Liebhold, A. M., and Bjørnstad, O. N.: Geographical variation in the periodicity of gypsy moth outbreaks, Ecography, 29, 367-374, https://doi.org/10.1111/j.2006.09067590.04448.x,2006.

Johansson, L. K.-H. and Alström, S.: Field resistance to willow leaf rust Melampsora epitea in inter- and intraspecific hybrids of Salix viminalis and S. dasyclados, Eur. J. Plant Pathol., 106, 763-769, https://doi.org/10.1023/A:1026573219481, 2000.

Jokinen, T., Berndt, T., Makkonen, R., Kerminen, V.-M., Junninen, H., Paasonen, P., Stratmann, F., Herrmann, H., Guenther, A. B., Worsnop, D. R., Kulmala, M., Ehn, M., and Sipilä, M.: Production of extremely low volatile organic compounds from biogenic emissions: Measured yields and atmospheric implications, P. Natl. Acad. Sci. USA, 112, 7123-7128, https://doi.org/10.1073/pnas.1423977112, 2015.

Joutsensaari, J., Yli-Pirilä, P., Korhonen, H., Arola, A., Blande, J. D., Heijari, J., Kivimäenpää, M., Mikkonen, S., Hao, L., Miettinen, P., Lyytikäinen-Saarenmaa, P., Faiola, C. L., Laaksonen, A., and Holopainen, J. K.: Biotic stress accelerates formation of climate-relevant aerosols in boreal forests, Atmos. Chem. Phys., 15, 12139-12157, https://doi.org/10.5194/acp-15-121392015, 2015.
Kaitaniemi, P. and Ruohomäki, K.: Effects of autumn temperature and oviposition date on timing of larval development and risk of parasitism in a spring folivore, Oikos, 84, 435-442, https://doi.org/10.2307/3546422, 1999.

Kaitaniemi, P., Ruohomäki, K., and Haukioja, E.: Consequences of defoliation on phenological interaction between Epirrita autumnata and its host plant, mountain birch, Funct. Ecol., 11, 199208, https://doi.org/10.1046/j.1365-2435.1997.00063.x, 1997.

Kaitaniemi, P., Ruohomäki, K., Ossipov, V., Haukioja, E., and Pihlaja, K.: Delayed induced changes in the biochemical composition of host plant leaves during an insect outbreak, Oecologia, 116, 182-190, https://doi.org/10.1007/s004420050578, 1998.

Kanakidou, M., Seinfeld, J. H., Pandis, S. N., Barnes, I., Dentener, F. J., Facchini, M. C., Van Dingenen, R., Ervens, B., Nenes, A., Nielsen, C. J., Swietlicki, E., Putaud, J. P., Balkanski, Y., Fuzzi, S., Horth, J., Moortgat, G. K., Winterhalter, R., Myhre, C. E. L., Tsigaridis, K., Vignati, E., Stephanou, E. G., and Wilson, J.: Organic aerosol and global climate modelling: a review, Atmos. Chem. Phys., 5, 1053-1123, https://doi.org/10.5194/acp-5-10532005, 2005.

Kanawade, V. P., Jobson, B. T., Guenther, A. B., Erupe, M. E., Pressley, S. N., Tripathi, S. N., and Lee, S.-H.: Isoprene suppression of new particle formation in a mixed deciduous forest, Atmos. Chem. Phys., 11, 6013-6027, https://doi.org/10.5194/acp11-6013-2011, 2011.

Karel, T. H. and Man, G.: Major Forest Insect and Disease Conditions in the United States: 2015 (No. FS-1093), U.S. Department of Agriculture, 2017.

Kari, E., Faiola, C. L., Isokääntä, S., Miettinen, P., Yli-Pirilä, P., Buchholz, A., Kivimäenpää, M., Mikkonen, S., Holopainen, J. K., and Virtanen, A.: Time-resolved characterization of biotic stress emissions from Scots pines being fed upon by pine weevil by means of PTR-ToF-MS, Boreal Environ. Res., 24, 25-49, 2019.

Kerminen, V.-M. and Kulmala, M.: Analytical formulae connecting the "real" and the "apparent" nucleation rate and the nuclei number concentration for atmospheric nucleation events, J. Aerosol Sci., 33, 609-622, https://doi.org/10.1016/S00218502(01)00194-X, 2002.

Kerminen, V.-M., Lihavainen, H., Komppula, M., Viisanen, Y., and Kulmala, M.: Direct observational evidence linking atmospheric aerosol formation and cloud droplet activation, Geophys. Res. Lett., 32, L14803, https://doi.org/10.1029/2005GL023130, 2005.

Kerminen, V.-M., Paramonov, M., Anttila, T., Riipinen, I., Fountoukis, C., Korhonen, H., Asmi, E., Laakso, L., Lihavainen, H., Swietlicki, E., Svenningsson, B., Asmi, A., Pandis, S. N., Kulmala, M., and Petäjä, T.: Cloud condensation nuclei production associated with atmospheric nucleation: a synthesis based on existing literature and new results, Atmos. Chem. Phys., 12, 1203712059, https://doi.org/10.5194/acp-12-12037-2012, 2012.

Kiendler-Scharr, A., Wildt, J., Dal Maso, M., Hohaus, T., Kleist, E., Mentel, T. F., Tillmann, R., Uerlings, R., Schurr, U., and Wahner, A.: New particle formation in forests inhibited by isoprene emissions, Nature, 461, 381-384, https://doi.org/10.1038/nature08292, 2009.

Kiendler-Scharr, A., Andres, S., Bachner, M., Behnke, K., Broch, S., Hofzumahaus, A., Holland, F., Kleist, E., Mentel, T. F., Rubach, F., Springer, M., Steitz, B., Tillmann, R., Wahner, A., Schnitzler, J.-P., and Wildt, J.: Isoprene in poplar emissions: 
effects on new particle formation and $\mathrm{OH}$ concentrations, Atmos. Chem. Phys., 12, 1021-1030, https://doi.org/10.5194/acp12-1021-2012, 2012.

Kirkby, J., Duplissy, J., Sengupta, K., Frege, C., Gordon, H., Williamson, C., Heinritzi, M., Simon, M., Yan, C., Almeida, J., Tröstl, J., Nieminen, T., Ortega, I. K., Wagner, R., Adamov, A., Amorim, A., Bernhammer, A.-K., Bianchi, F., Breitenlechner, M., Brilke, S., Chen, X., Craven, J., Dias, A., Ehrhart, S., Flagan, R. C., Franchin, A., Fuchs, C., Guida, R., Hakal, J., Hoyle, C. R., Jokinen, T., Junninen, H., Kangasluoma, J., Him, J., Krapf, M., Kürten, A., Laaksonen, A., Lehtipalo, K., Makhmutov, V., Mathot, S., Molteni, U., Onnela, A., Peräkylä, O., Piel, F., Petäjä, T., Praplan, A. P., Pringle, K., Rap, A., Richards, N. A. D., Riipinen, I., Rissanen, M. P., Rondo, L., Sarnela, N., Schobesberger, S., Scott, C. E., Seinfeld, J. H., Sipilä, M., Steiner, G., Stozhkov, Y., Stratmann, F., Tomé, A., Virtanen, A., Vogel, A. L., Wagner, A. C., Wagner, P. E., Weingartner, E., Wimmer, D., Winkler, P. M., Ye, P., Zhang, X., Hansel, A., Dommen, J., Donahue, N. M., Worsnop, D. R., Baltensperger, U., Kulmala, M., Carslaw, K. S., and Curtius, J.: Ion-induced nucleation of pure biogenic particles, Nature, 533, 521-526, https://doi.org/10.1038/nature17953, 2016.

Kivimäenpää, M., Ghimire, R. P., Sutinen, S., Häikiö, E., Kasurinen, A., Holopainen, T., and Holopainen, J. K.: Increases in volatile organic compound emissions of Scots pine in response to elevated ozone and warming are modified by herbivory and soil nitrogen availability, Eur. J. For. Res., 135, 343-360, https://doi.org/10.1007/s10342-016-0939-x, 2016.

Klemola, T., Ruohomäki, K., Andersson, T., and Neuvonen, S.: Reduction in size and fecundity of the autumnal moth, Epirrita autumnata, in the increase phase of a population cycle, Oecologia, 141, 47-56, https://doi.org/10.1007/s00442-004-1642-z, 2004.

Komppula, M., Sihto, S.-L., Korhonen, H., Lihavainen, H., Kerminen, V.-M., Kulmala, M., and Viisanen, Y.: New particle formation in air mass transported between two measurement sites in Northern Finland, Atmos. Chem. Phys., 6, 2811-2824, https://doi.org/10.5194/acp-6-2811-2006, 2006.

Kula, E., Pešlová, A., Martinek, P., and Mazal, P.: The development of caterpillars of gypsy moth (Lymantria dispar L.) feeding on food affected by nitrogen, Sumar. List, 137, 51-60, 2013.

Kulmala, M., Petäjä, T., Nieminen, T., Sipilä, M., Manninen, H. E., Lehtipalo, K., Dal Maso, M., Aalto, P. P., Junninen, H., Paasonen, P., Riipinen, I., Lehtinen, K. E. J., Laaksonen, A., and Kerminen, V.-M.: Measurement of the nucleation of atmospheric aerosol particles, Nat. Protoc., 7, 1651-1667, https://doi.org/10.1038/nprot.2012.091, 2012.

Kulmala, M., Kontkanen, J., Junninen, H., Lehtipalo, K., Manninen, H. E., Nieminen, T., Petäjä, T., Sipilä, M., Schobesberger, S., Rantala, P., Franchin, A., Jokinen, T., Järvinen, E., Äijälä, M., Kangasluoma, J., Hakala, J., Aalto, P. P., Paasonen, P., Mikkilä, J., Vanhanen, J., Aalto, J., Hakola, H., Makkonen, U., Ruuskanen, T., Mauldin, R. L. III, Duplissy, J., Vehkamäki, H., Bäck, J., Kortelainen, A., Riipinen, I., Kurtén, T., Johnston, M. V., Smith, J. N., Ehn, M., Mente,1 T. F., Lehtinen, K. E. J., Laaksonen, A., Kerminen, V.-M., and Worsnop, D. R.: Direct observations of atmospheric aerosol nucleation, Science, 339, 943-946, https://doi.org/10.1126/science.1227385, 2013.

Kulmala, M., Petäjä, T., Ehn, M., Thornton, J., Sipilä, M., Worsnop, D. R., Kerminen, V.-M.: Chemistry of atmospheric nucleation: on the recent advances on precursor characterization and atmospheric cluster composition in connection with atmospheric new particle formation, Annu. Rev. Phys. Chem., 65, 2137, https://doi.org/10.1146/annurev-physchem-040412-110014, 2014.

Kyrö, E.-M., Väänänen, R., Kerminen, V.-M., Virkkula, A., Petäjä, T., Asmi, A., Dal Maso, M., Nieminen, T., Juhola, S., Shcherbinin, A., Riipinen, I., Lehtipalo, K., Keronen, P., Aalto, P. P., Hari, P., and Kulmala, M.: Trends in new particle formation in eastern Lapland, Finland: effect of decreasing sulfur emissions from Kola Peninsula, Atmos. Chem. Phys., 14, 4383-4396, https://doi.org/10.5194/acp-14-4383-2014, 2014.

Lee, S.-H., Uin, J., Guenther, A. B., de Gouw, J. A., Yu, F., Nadykto, A. B., Herb, J., Ng, N. L., Koss, A., Brune, W. B., Baumann, K., Kanawade, V. P., Keutsch, F. N., Nenes, A., Olsen, K., Goldstein, A., and Ouyang, Q.: Isoprene suppression of new particle formation: Potential mechanisms and implications, J. Geophys. Res., 121, 14621-14635, https://doi.org/10.1002/2016JD024844, 2016.

Lehtinen, K. E. J., Dal Maso, M., Kulmala, M., and Kerminen, V. M.: Estimating nucleation rates from apparent particle formation rates and vice versa: Revised formulation of the Kerminen-Kulmala equation, J. Aerosol Sci., 38, 988-994, https://doi.org/10.1016/j.jaerosci.2007.06.009, 2007.

Lelieveld, J., Butler, T. M., Crowley, J. N., Dillon, T. J., Fischer, H., Ganzeveld, L., Harder, H., Lawrence, M. G., Martinez, M., Taraborrelli, D., and Williams, J.: Atmospheric oxidation capacity sustained by a tropical forest, Nature, 452, 737-740, https://doi.org/10.1038/nature06870, 2008.

Lempa, K., Agrawal, A. A., Salminen, J.P., Turunen, T., Ossipov, V., Ossipova, S., Haukioja, E., and Pihlaja, K.: Rapid herbivore-induced changes in mountain birch phenolics and nutritive compounds and their effects on performance of the major defoliator, Epirrita autumnata, J. Chem. Ecol., 30, 303-321, https://doi.org/10.1023/B:JOEC.0000017979.94420.78, 2004.

Li, T., Holst, T., Michelsen, A., and Rinnan, R.: Amplification of plant volatile defence against insect herbivory in a warming Arctic tundra, Nat. Plants, 5, 568-574, https://doi.org/10.1038/s41477-019-0439-3, 2019.

Lin, Y. H., Zhang, H., Pye, H. O. T., Zhang, Z., Marth, W. J., Park, S., Arashiro, M., Cui, T., Budisulistiorini, S. H., Sexton, K. G., Vizuete, W., Xie, Y., Luecken, D. J., Piletic, I. R., Edney, E. O., Bartolotti, L. J., Gold, A., and Surratt, J. D.: Epoxide as a precursor to secondary organic aerosol formation from isoprene photooxidation in the presence of nitrogen oxides, P. Natl. Acad. Sci. USA, 110, 6718-6723, https://doi.org/10.1073/pnas.1221150110, 2013.

Major, I. T., Nicole, M.-C., Duplessis, S., and Seguin, A.: Photosynthetic and respiratory changes in leaves of poplar elicited by rust infection, Photosynth. Res., 104, 41-48, https://doi.org/10.1007/s11120-009-9507-2, 2010.

Makkonen, R., Asmi, A., Korhonen, H., Kokkola, H., Järvenoja, S., Räisänen, P., Lehtinen, K. E. J., Laaksonen, A., Kerminen, V.M., Järvinen, H., Lohmann, U., Bennartz, R., Feichter, J., and Kulmala, M.: Sensitivity of aerosol concentrations and cloud properties to nucleation and secondary organic distribution in ECHAM5-HAM global circulation model, Atmos. Chem. Phys., 9, 1747-1766, https://doi.org/10.5194/acp-9-1747-2009, 2009. 
Marçais, B. and Desprez-Loustau, M.-L.: European oak powdery mildew: impact on trees, effects of environmental factors, and potential effects of climate change, Ann. For. Sci., 71, 633-642, https://doi.org/10.1007/s13595-012-0252-x, 2014.

Marçais, B., Kavkova, M., and Desprez-Loustau, M.-L.: Phenotypic variation in the phenology of ascospore production between European populations of oak powdery mildew, Ann. For. Sci., 66, 814-822, https://doi.org/10.1051/forest/2009077, 2009.

McFiggans, G., Mentel, T. F., Wildt, J., Pullinen, I., Kang, S., Kleist, E., Schmitt, S., Springer, M., Tillmann, R., Wu, C., Zhao, D., Hallquist, M., Faxon, C., Le Breton, M., Hallquist, A. M., Simpson, D., Bergström, R., Jenkin, M. E., Ehn, M., Thornton, J. A., Alfarra, M. R., Bannan, T. J., Percival, C. J., Priestley, M., Topping, D., and Kiendler-Scharr, A.: Secondary organic aerosol reduced by mixture of atmospheric vapours, Nature, 565, 587-593, https://doi.org/10.1038/s41586-018-0871-y, 2019.

McManus, M., Schneeberger, N., Reardon, R., and Mason, G.: Forest insect and disease (No 162): Gypsy Moth, Washington, D.C., United States Department of Agriculture Forest Service, 1989.

Mentel, Th. F., Kleist, E., Andres, S., Dal Maso, M., Hohaus, T., Kiendler-Scharr, A., Rudich, Y., Springer, M., Tillmann, R., Uerlings, R., Wahner, A., and Wildt, J.: Secondary aerosol formation from stress-induced biogenic emissions and possible climate feedbacks, Atmos. Chem. Phys., 13, 8755-8770, https://doi.org/10.5194/acp-13-8755-2013, 2013.

Merikanto, J., Spracklen, D. V., Mann, G. W., Pickering, S. J., and Carslaw, K. S.: Impact of nucleation on global CCN, Atmos. Chem. Phys., 9, 8601-8616, https://doi.org/10.5194/acp-9-86012009, 2009.

Miller, J. C., Hanson, P. E., and Kimberling, D. N.: Development of the gypsy moth (Lepidoptera: Lymantriidae) on garry oak and red alder in Western North America, Environ. Entomol., 20, 10971101, https://doi.org/10.1093/ee/20.4.1097, 1991.

Mogensen, D., Smolander, S., Sogachev, A., Zhou, L., Sinha, V., Guenther, A., Williams, J., Nieminen, T., Kajos, M. K., Rinne, J., Kulmala, M., and Boy, M.: Modelling atmospheric OH-reactivity in a boreal forest ecosystem, Atmos. Chem. Phys., 11, 97099719, https://doi.org/10.5194/acp-11-9709-2011, 2011.

Mogensen, D., Gierens, R., Crowley, J. N., Keronen, P., Smolander, S., Sogachev, A., Nölscher, A. C., Zhou, L., Kulmala, M., Tang, M. J., Williams, J., and Boy, M.: Simulations of atmospheric OH, $\mathrm{O}_{3}$ and $\mathrm{NO}_{3}$ reactivities within and above the boreal forest, Atmos. Chem. Phys., 15, 3909-3932, https://doi.org/10.5194/acp15-3909-2015, 2015.

Monson, R. K., Harley, P. C., Litvak, M. E., Wildermuth, M., Guenther, A. B., Zimmerman, P. R., and Fall, R.: Environmental and developmental controls over the seasonal pattern of isoprene emission from aspen leaves, Oecologia, 99, 260-270, https://doi.org/10.1007/BF00627738, 1994.

Mutzel, A., Poulain, L., Berndt, T., Iinuma, Y., Rodigast, M., Böge, O., Richters, S., Spindler, G., Sipilä, M., Jokinen, T., Kulmala, M., and Herrmann, H.: Highly oxidized multifunctional organic compounds observed in tropospheric particles: a field and laboratory study, Environ. Sci. Technol., 49, 7754-7761, https://doi.org/10.1021/acs.est.5b00885, 2015.

Naja, M., Akimoto, H., and Staehelin, J.: Ozone in background and photochemically aged air over central Europe: analysis of long-term ozonesonde data from Hohen- peissenberg and Payerne, J. Geophys. Res., 108, 4063, https://doi.org/10.1029/2002JD002477 2003.

Nieminen, T., Lehtinen, K. E. J., and Kulmala, M.: Sub-10 nm particle growth by vapor condensation - effects of vapor molecule size and particle thermal speed, Atmos. Chem. Phys., 10, 97739779, https://doi.org/10.5194/acp-10-9773-2010, 2010.

Nieminen, T., Asmi, A., Dal Maso, M., Aalto, P. P., Keronen, P., Petäjä, T., Kulmala, M., and Kerminen, V.-M.: Trends in atmospheric new-particle formation: 16 years of observations in a boreal-forest environment, Boreal Environ. Res., 19, 191-214, 2014.

Nieminen, T., Yli-Juuti, T., Manninen, H., Petäjä, T., Kerminen, V.-M., and Kulmala, M.: Technical note: New particle formation event forecasts during PEGASOS-Zeppelin Northern mission 2013 in Hyytiälä, Finland, Atmos. Chem. Phys., 15, 1238512396, https://doi.org/10.5194/acp-15-12385-2015, 2015.

Niinemets, Ü.: Mild versus severe stress and BVOCs: thresholds, priming and consequences, Trends Plant Sci., 15, 145-153, https://doi.org/10.1016/j.tplants.2009.11.008, 2010.

Niinemets, Ü., Reichstein, M., Staudt, M., Seufert, G., and Tenhunen, J. D.: Stomatal constraints may affect emission of oxygenated monoterpenoids from the foliage of Pinus pinea, Plant Physiol., 130, 1371-1385, https://doi.org/10.1104/pp.009670, 2002.

Niinemets Ü., Kännaste, A., and Copolovici, L.: Quantitative patterns between plant volatile emissions induced by biotic stresses and the degree of damage, Front. Plant Sci., 4, 262, https://doi.org/10.3389/fpls.2013.00262, 2013.

Nikula, A.: Animals as forest pests in Finnish Lapland, in: Forest Pathological Research in Northern Forests with a Special Reference to Abiotic Stress Factors, edited by: Jalkanen, R., Aalto, T., and Lahti, M.-L., Extended SNS Meeting in Forest Pathology, Lapland, Finland, 3-7 August 1992, Finnish Forest Research Institute, Research Papers 451, 22-29, 1993.

Nölscher, A. C., Williams, J., Sinha, V., Custer, T., Song, W., Johnson, A. M., Axinte, R., Bozem, H., Fischer, H., Pouvesle, N., Phillips, G., Crowley, J. N., Rantala, P., Rinne, J., Kulmala, M., Gonzales, D., Valverde-Canossa, J., Vogel, A., Hoffmann, T., Ouwersloot, H. G., Vilà-Guerau de Arellano, J., and Lelieveld, J.: Summertime total $\mathrm{OH}$ reactivity measurements from boreal forest during HUMPPA-COPEC 2010, Atmos. Chem. Phys., 12, 8257-8270, https://doi.org/10.5194/acp-12-8257-2012, 2012.

Nölscher, A. C., Yañez-Serrano, A. M., Wolff, S., Carioca de Araujo, A., Lavrič, J. V., Kesselmeier, J., and Williams, J.: Unexpected seasonality in quantity and composition of Amazon rainforest air reactivity, Nat. Commun., 7, 10383, https://doi.org/10.1038/ncomms10383, 2016.

Oláh, V., Szőllősi, E., Lakatos, Á., Kanalas, P., Nyitrai, B., and Mészáros, I.: Springtime leaf development of mature sessile oak trees as based on multi-seasonal monitoring data, Acta Silv. Lign. Hung., 8, 21-30, https://doi.org/10.2478/v10303-0120002-7, 2012.

Paasonen, P., Nieminen, T., Asmi, E., Manninen, H. E., Petäjä, T., Plass-Dülmer, C., Flentje, H., Birmili, W., Wiedensohler, A., Hõrrak, U., Metzger, A., Hamed, A., Laaksonen, A., Facchini, M. C., Kerminen, V.-M., and Kulmala, M.: On the roles of sulphuric acid and low-volatility organic vapours in the initial steps of atmospheric new particle formation, Atmos. Chem. 
Phys., 10, 11223-11242, https://doi.org/10.5194/acp-10-112232010, 2010.

Paasonen, P., Asmi, A., Petäjä, T., Kajos, M. K., Äijälä, M., Junninen, H., Holst, T., Abbatt, J. P. D., Arneth, A., Birmili, W., van der Gon, H. D., Hamed, A., Hoffer, A., Laakso, L., Laaksonen, A., Leaitch, W. R., Plass-Dülmer, C., Pryor, S. C., Räisänen, P., Swietlicki, E., Wiedensohler, A., Worsnop, D. R., Kerminen, V.-M., and Kulmala, M.: Warming-induced increase in aerosol number concentration likely to moderate climate change, Nat. Geosci., 6, 438-442, https://doi.org/10.1038/ngeo1800, 2013.

Pacifico, F., Folberth, G. A., Sitch, S., Haywood, J. M., Rizzo, L. V., Malavelle, F. F., and Artaxo, P.: Biomass burning related ozone damage on vegetation over the Amazon forest: a model sensitivity study, Atmos. Chem. Phys., 15, 2791-2804, https://doi.org/10.5194/acp-15-2791-2015, 2015.

Pautasso, M., Döring, T. F., Garbelotto, M., Pellis, L., and Jeger, M. J.: Impacts of climate change on plant diseases - opinions and trends, Eur. J. Plant Pathol., 133, 295-313, https://doi.org/10.1007/s10658-012-9936-1, 2012.

Perez-Rial, D., Penuelas, J., Lopez-Mahia, P., and Llusia, J.: Terpenoid emissions from Quercus robur, A case study of Galicia (NW Spain), J. Environ. Monitor., 11, 1268-1275, https://doi.org/10.1039/b819960d, 2009.

Petäjä, T., Mauldin, III, R. L., Kosciuch, E., McGrath, J., Nieminen, T., Paasonen, P., Boy, M., Adamov, A., Kotiaho, T., and Kulmala, M.: Sulfuric acid and $\mathrm{OH}$ concentrations in a boreal forest site, Atmos. Chem. Phys., 9, 7435-7448, https://doi.org/10.5194/acp9-7435-2009, 2009.

Petron, G., Harley, P., Greenberg, J., and Guenther, A.: Seasonal temperature variations influence isoprene emission, Geophys. Res. Lett., 28, 1707-1710, https://doi.org/10.1029/2000GL011583, 2001.

Pinon, J., Frey, P., and Husson, C.: Wettability of poplar leaves influences dew formation and infection by Melampsora laricipopulina, Plant Dis., 90, 177-184, https://doi.org/10.1094/PD-900177, 2006.

Pöhlker, C., Wiedemann, K. T., Sinha, B., Shiraiwa, M., Gunthe, S. S., Smith, M., Su, H., Artaxo, P., Chen, Q., Cheng, Y., Elbert, W., Gilles, M. K., Kilcoyne, A. L. D., Moffet, R. C., Weigand, M., Martin, S. T., Pöschl, U., and Andreae, M. O.: Biogenic potassium salt particles as seeds for secondary organic aerosol in the Amazon, Science, 337, 1075-1078, https://doi.org/10.1126/science.1223264, 2012.

Pöschl, U., Martin, S. T., Sinha, B., Chen, Q., Gunthe, S. S., Huffman, J. A., Borrmann, S., Farmer, D. K., Garland, R. M., Helas, G., Jimenez, J. L., King, S. M., Manzi, A., Mikhailov, E., Pauliquevis, T., Petters, M. D., Prenni, A. J., Roldin, P., Rose, D., Schneider, J., Su, H., Zorn, S. R., Artaxo, P., and O., A. M.: Rainforest aerosols as biogenic nuclei of clouds and precipitation in the Amazon, Science, 329, 1513-1516, https://doi.org/10.1126/science.1191056, 2010.

Praplan, A. P., Tykkä, T., Chen, D., Boy, M., Taipale, D., Vakkari, V., Zhou, P., Petäjä, T., and Hellén, H.: Long-term total OH reactivity measurements in a boreal forest, Atmos. Chem. Phys., 19, 14431-14453, https://doi.org/10.5194/acp-19-14431-2019, 2019.

Pullinen, I., Schmitt, S., Kang, S., Sarrafzadeh, M., Schlag, P., Andres, S., Kleist, E., Mentel, T. F., Rohrer, F., Springer, M., Tillmann, R., Wildt, J., Wu, C., Zhao, D., Wahner, A., and Kiendler-Scharr, A.: Impact of NOx on secondary organic aerosol (SOA) formation from $\alpha$-pinene and $\beta$-pinene photooxidation: the role of highly oxygenated organic nitrates, Atmos. Chem. Phys., 20, 10125-10147, https://doi.org/10.5194/acp-2010125-2020, 2020.

Quéléver, L. L. J., Kristensen, K., Normann Jensen, L., Rosati, B., Teiwes, R., Daellenbach, K. R., Peräkylä, O., Roldin, P., Bossi, R., Pedersen, H. B., Glasius, M., Bilde, M., and Ehn, M.: Effect of temperature on the formation of highly oxygenated organic molecules (HOMs) from alpha-pinene ozonolysis, Atmos. Chem. Phys., 19, 7609-7625, https://doi.org/10.5194/acp19-7609-2019, 2019.

Radhakrishnan, K. and Hindmarsh, A. C.: Description and use of LSODE, the Livermore Solver for Ordinary Differential Equations, LLNL report UCRL-ID-113855, LLNL, United States, https://doi.org/10.2172/15013302, 1993.

Riccobono, F., Schobesberger, S., Scott, C. E., Dommen, J., Ortega, I. K., Rondo, L., Almeida, J., Amorim, A., Bianchi, F., Breitenlechner, M., David, A., Downard, A., Dunne, E. M., Duplissy, J., Ehrhart, S., Flagan, R. C., Franchin, A., Hansel, A., Junninen, H., Kajos, M., Keskinen, H., Kupc, A., Kürten, A., Kvashin, A. N., Laaksonen, A., Lehtipalo, K., Makhmutov, V., Mathot, S., Nieminen, T., Onnela, A., Petäjä, T., Praplan, A. P., Santos, F. D., Schallhart, S., Seinfeld, J. H., Sipilä, M., Spracklen, D. V., Stozhkov, Y., Stratmann, F., Tomé, A., Tsagkogeorgas, G., Vaattovaara, P., Viisanen, Y., Vrtala, A., Wagner, P. E., Weingartner, E., Wex, H., Wimmer, D., Carslaw, K. S., Curtius, J., Donahue, N. M., Kirkby, J., Kulmala, M., Worsnop, D. R., and Baltensperger, U.: Oxidation products of biogenic emissions contribute to nucleation of atmospheric particles, Science, 344, 717721, https://doi.org/10.1126/science.1243527, 2014.

Rieksta, J., Li, T., Junker, R. R., Jepsen, J. U., Ryde, I., and Rinnan, R.: Insect herbivory strongly modifies mountain birch volatile emissions, Front. Plant Sci., 11, 558979, https://doi.org/10.3389/fpls.2020.558979, 2020.

Riipi, M., Lempa, K., Haukioja, E., Ossipov, V., and Pihlaja, K.: Effects of simulated winter browsing on mountain birch foliar chemistry and on the performance of insect herbivores, Oikos, 111, 221-234, https://doi.org/10.1111/j.00301299.2005.13781.x, 2005.

Riipinen, I., Yli-Juuti, T., Pierce, J. R., Petäjä, T., Worsnop, D. R., Kulmala, M., and Donahue, N. M.: The contribution of organics to atmospheric nanoparticle growth, Nat. Geosci., 5, 453-458, https://doi.org/10.1038/ngeo1499, 2012.

Rohrer, F. and Berresheim, H.: Strong correlation between levels of tropospheric hydroxyl radicals and solar ultraviolet radiation, Nature, 442, 184-187, https://doi.org/10.1038/nature04924, 2006.

Rosenfeld, D., Andreae, M. O., Asmi, A., Chin, M., de Leeuw, G., Donovan, D. P., Kahn, R., Kinne, S., Kivekäs, N., Kulmala, M., Lau, W., Schmidt, S., Suni, T., Wagner, T., Wildt, M., and Quass, J.: Global observations of aerosol-cloudprecipitation-climate interactions, Rev. Geophys., 52, 750-808, https://doi.org/10.1002/2013RG000441, 2014.

Ruohomäki, K., Tanhuanpää, M., Ayres, M. P., Kaitaniemi, P., Tammaru, T., and Haukioja, E.: Causes of cyclicity of Epirrita autumnata (Lepidoptera, Geometridae): grandiose theory and tedious practice, Popul. Ecol., 42, 211-223, https://doi.org/10.1007/PL00012000, 2000. 
Ruuhola, T., Salminen, J.-P., Haviola, S., Yang, S., and Rantala, M. J.: Immunological memory of mountain birches: effects of phenolics on performance of the autumnal moth depend on herbivory history of trees, J. Chem. Ecol., 33, 1160-1176, https://doi.org/10.1007/s10886-007-9308-z, 2007.

Ruuskanen, T. M., Reissell, A., Keronen, P., Aalto, P. P., Laakso, L., Grönholm, T., Hari, P., and Kulmala, M.: Atmospheric trace gas and aerosol particle concentration measurements in Eastern Lapland, Finland 1992-2001, Boreal Environ. Res., 8, 335-349, 2003.

Schaub, A., Blande, J. D., Graus, M., Oksanen, E., Holopainen, J. K., and Hansel, A.: Real-time monitoring of herbivore induced volatile emissions in the field, Physiol. Plant., 138, 123-133, https://doi.org/10.1111/j.1399-3054.2009.01322.x, 2010.

Schnitzler, J.-P., Lehning, A., and Steinbrecher, R.: Seasonal pattern of isoprene synthase activity in Quercus robur leaves and its significance for modeling isoprene emission rates, Bot. Acta, 110, 240-243, https://doi.org/10.1111/j.14388677.1997.tb00635.x, 1997.

Schobesberger, S., Junninen, H., Bianchi, F., Lönn, G., Ehn, M., Lehtipalo, K., Dommen, J., Ehrhart, S., Ortega, I. K., Franchin, A., Nieminen, T., Riccobono, F., Hutterli, M., Duplissy, J., Almeida, J., Amorim, A., Breitenlechner, M., Downard, A. J., Dunne, E. M., Flagan, R. C., Kajos, M., Keskinen, H., Kirkby, J., Kupc, A., Kürten, A., Kurtén, T., Laaksonen, A., Mathot, S., Onnela, A., Praplan, A. P., Rondo, L., Santos, F. D., Schallhart, S., Schnitzhofer, R., Sipilä, M., Tomé, A., Tsagkogeorgas, G., Vehkamäki, H., Wimmer, D., Baltensperger, U., Carslaw, K. S., Curtius, J., Hansel, A., Petäjä, T., Kulmala, M., Donahue, N. M., and Worsnop, D. R.: Molecular understanding of atmospheric particle formation from sulfuric acid and large oxidized organic molecules, P. Natl. Acad. Sci USA, 110, 17223-17228, https://doi.org/10.1073/pnas.1306973110, 2013.

Seidel, D. J., Zhang, Y., Beljaars, A., Golaz, J.-C., Jacobson, A. R., and Medeiros, B.: Climatology of the planetary boundary layer over the continental United States and Europe, J. Geophys. Res. A, 117, D17106, https://doi.org/10.1029/2012JD018143, 2012.

Shifflett, S. D., Hazel, D. W., and Guthrie Nichols, E.: Subsoiling and genotype selection improves Populus productivity grown on a North Carolina sandy soil, Forests, 7, 74-84, https://doi.org/10.3390/f7040074, 2016.

Simon, M., Dada, L., Heinritzi, M., Scholz, W., Stolzenburg, D., Fischer, L., Wagner, A. C., Kürten, A., Rörup, B., He, X.-C., Almeida, J., Baalbaki, R., Baccarini, A., Bauer, P. S., Beck, L., Bergen, A., Bianchi, F., Bräkling, S., Brilke, S., Caudillo, L., Chen, D., Chu, B., Dias, A., Draper, D. C., Duplissy, J., El-Haddad, I., Finkenzeller, H., Frege, C., Gonzalez-Carracedo, L., Gordon, H., Granzin, M., Hakala, J., Hofbauer, V., Hoyle, C. R., Kim, C., Kong, W., Lamkaddam, H., Lee, C. P., Lehtipalo, K., Leiminger, M., Mai, H., Manninen, H. E., Marie, G., Marten, R., Mentler, B., Molteni, U., Nichman, L., Nie, W., Ojdanic, A., Onnela, A., Partoll, E., Petäjä, T., Pfeifer, J., Philippov, M., Quéléver, L. L. J., Ranjithkumar, A., Rissanen, M. P., Schallhart, S., Schobesberger, S., Schuchmann, S., Shen, J., Sipilä, M., Steiner, G., Stozhkov, Y., Tauber, C., Tham, Y. J., Tomé, A. R., Vazquez-Pufleau, M., Vogel, A. L., Wagner, R., Wang, M., Wang, D. S., Wang, Y., Weber, S. K., Wu, Y., Xiao, M., Yan, C., Ye, P., Ye, Q., Zauner-Wieczorek, M., Zhou, X., Baltensperger, U., Dommen, J., Flagan, R. C., Hansel, A., Kulmala,
M., Volkamer, R., Winkler, P. M., Worsnop, D. R., Donahue, N. M., Kirkby, J., and Curtius, J.: Molecular understanding of newparticle formation from $\alpha$-pinene between -50 and $+25^{\circ} \mathrm{C}$, Atmos. Chem. Phys., 20, 9183-9207, https://doi.org/10.5194/acp20-9183-2020, 2020.

Simpson, D. Winiwarter, W., Börjesson, G., Cinderby, S., Ferreiro, A., Guenther, A., Hewitt, C. N., Janson, R., Aslam K. Khalil, M., Owen, S., Pierce, T. E., Puxbaum, H., Shearer, M., Skiba, U., Steinbrecher, R., Tarrasón, L., and Öquist, M. G.: Inventorying emissions from Nature in Europe, J. Geophys. Res. A, 104, 8113-8152, https://doi.org/10.1029/98JD02747, 1999.

Simpson, D., Benedictow, A., Berge, H., Bergström, R., Emberson, L. D., Fagerli, H., Flechard, C. R., Hayman, G. D., Gauss, M., Jonson, J. E., Jenkin, M. E., Nyíri, A., Richter, C., Semeena, V. S., Tsyro, S., Tuovinen, J.-P., Valdebenito, Á., and Wind, P.: The EMEP MSC-W chemical transport model - technical description, Atmos. Chem. Phys., 12, 7825-7865, https://doi.org/10.5194/acp-12-7825-2012, 2012.

Sinha, V., Williams, J., Lelieveld, J., Ruuskanen, T. M., Kajos, M. K., Patokoski, J., Hellén, H., Hakola, H., Mogensen, D., Boy, M., Rinne, J., and Kulmala, M.: OH reactivity measurements within a boreal forest: evidence for unknown reactive emissions, Environ. Sci. Technol., 44, 6614-6620, 2010.

Smiatek, G. and Steinbrecher, R.: Temporal and spatial variation of forest VOC emissions inGermany in the decade 1994-2003, Atmos. Environ., 40, 166-177, https://doi.org/10.1016/j.atmosenv.2005.11.071, 2006.

Spear, R. J.: The Great Gypsy Moth War: A history of the first campaign in Massachusetts to eradicate the gypsy moth, 1890-1901, University of Massachusetts Press, Amherst, 2005.

Spracklen, D. V., Carslaw, K. S., Kulmala, M., Kerminen, V.-M., Sihto, S.-L., Riipinen, I., Merikanto, J., Mann, G. W., Chipperfield, M. P., Wiedensohler, A., Birmili, W., and Lihavainen, H.: Contribution of particle formation to global cloud condensation nuclei concentrations, Geophys. Res. Lett., 35, L06808, https://doi.org/10.1029/2007GL033038, 2008.

Stolzenburg, D., Fischer, L., Vogel, A. L., Heinritzi, M., Schervish, M., Simon, M., Wagner, A. C., Dada, L., Ahonen, L. R., Amorim, A., Baccarini, A., Bauer, P. S., Baumgartner, B., Bergen, A., Bianchi, F., Breitenlechner, M., Brilke, S., Mazon, S. B., Chen, D., Dias, A., Draper, D. C., Duplissy, J., El Haddad, I., Finkenzeller, H., Frege, C., Fuchs, C., Garmash, O., Gordon, H., He, X., Helm, J., Hofbauer, V., Hoyle, C. R., Kim, C., Kirkby, J., Kontkanen, J., Kürten, A., Lampilahti, J., Lawler, M., Lehtipalo, K., Leiminger, M., Mai, H., Mathot, S., Mentler, B., Molteni, U., Nie, W., Nieminen, T., Nowak, J. B., Ojdanic, A., Onnela, A., Passananti, M., Petäjä, T., Quéléver, L. L. J., Rissanen, M. P., Sarnela, N., Schallhart, S., Tauber, C., Tomé, A., Wagner, R., Wang, M., Weitz, L., Wimmer, D., Xiao, M., Yan, C., Ye, P., Zha, Q., Baltensperger, U., Curtius, J., Dommen, J., Flagan, R. C., Kulmala, M., Smith, J. N., Worsnop, D. R., Hansel, A., Donahue, N. M., and Winkler, P. M.: Rapid growth of organic aerosol nanoparticles over a wide tropospheric temperature range, P. Natl. Acad. Sci. USA, 115, 9122-9127, https://doi.org/10.1073/pnas.1807604115, 2018.

Stoyenoff, J. L., Witter, J. A., and Montgomery, M. E.: Nutritional indices in the gypsy moth (Lymantria dispar (L.)) under field conditions and host switching situations, Oecologia, 97, 158170, https://doi.org/10.1007/BF00323145, 1994. 
Sun, Z., Copolovici, L., and Niinemets, Ü.: Can the capacity for isoprene emission acclimate to environmental modifications during autumn senescence in temperate deciduous tree species Populus tremula?, J. Plant Res., 125, 263-274, https://doi.org/10.1007/s10265-011-0429-7, 2012.

Surratt, J. D., Chan, A. W. H., Eddingsaas, N. C., Chan, M., Loza, C. L., Kwan, A. J., Hersey, S. P., Flagan, R. C., Wennberg, P. O., and Seinfeld, J. H.: Reactive intermediates revealed in secondary organic aerosol formation from isoprene, P. Natl. Acad. Sci. USA, 107, 6640-6645, https://doi.org/10.1073/pnas.0911114107, 2010.

Taipale, D.: Impact of biotic and environmental stress and perturbations of Scots pines on formation and growth of atmospheric aerosol particles - a modelling study with quantitative estimates, in preparation, 2021.

Taipale, D., Aalto, J., Schiestl-Aalto, P., Kulmala, M., and Bäck, J.: The importance of accounting for enhanced emissions of monoterpenes from new Scots pine foliage in models - A Finnish case study, Atmos. Environ. X., 8, 100097, https://doi.org/10.1016/j.aeaoa.2020.100097, 2020.

Tammaru, T., Kaitaniemi, P., and Ruohomäki, K.: Realized fecundity in Epirrita autumnata (Lepidoptera: Geometridae): relation to body size and consequences to population dynamics, Oikos, 77, 407-16, https://doi.org/10.2307/3545931, 1996.

Taraborrelli, D., Lawrence, M., G., Crowley, J. N., Dillon, T. J., Gromov, S., Groß, C. B. M., Vereecken, L., and Lelieveld, J.: Hydroxyl radical buffered by isoprene oxidation over tropical forests, Nat. Geosci., 5, 190-193, https://doi.org/10.1038/ngeo1405, 2012.

Tenow, O.: Topographical dependence of an outbreak of oporinia autumnata Bkh. (lep., geometridae) in a mountain birch forest in northern Sweden, Zoon, 3, 85-110, 1975.

Tripathi, A. M., Fischer, M., Orság, M., Marek, M. V., Žalud, Z., and Trnka, M.: Evaluation of indirect measurement method of seasonal patterns of leaf area index in a high-density short rotation coppice culture of poplar, Acta Univ. Agric. Silvic. Mendelianae Brun., 64, 549-556, https://doi.org/10.11118/actaun201664020549, 2016.

Tröstl, J., Chuang, W. K., Gordon, H., Heinritzi, M., Yan, C., Molteni, U., Ahlm, L., Frege, C., Bianchi, F., Wagner, R., Simon, M., Lehtipalo, K., Williamson, C., Craven, J. S., Duplissy, J., Adamov, A., Almeida, J., Bernhammer, A.-K., Breitenlechner, M., Brilke, S., Dias, A., Ehrhart, S., Flagan, R. C., Franchin, A., Fuchs, C., Guida, R., Gysel, M., Hansel, A., Hoyle, C. R., Jokinen, T., Junninen, H., Kangasluoma, J., Keskinen, H., Kim, J., Krapf, M., Kürten, A., Laaksonen, A., Lawler, M., Leiminger, M., Mathot, S., Möhler, O., Nieminen, T., Onnela, A., Petäjä, T., Piel, F. M., Miettinen, P., Rissanen, M. P., Rondo, L., Sarnela, N., Schobesberger, S., Sengupta, K., Sipilä, M., Smith, J. N., Steiner, G., Tomè, A., Virtanen, A., Wagner, A. C., Weingartner, E., Wimmer, D., Winkler, P. M., Ye, P., Carslaw, K. S., Curtius, J., Dommen, J., Kirkby, J., Kulmala, M., Riipinen, I., Worsnop, D. R., Donahue, N. M., and Baltensperger, U.: The role of low-volatility organic compounds in initial particle growth in the atmosphere, Nature, 533, 527-531, https://doi.org/10.1038/nature18271, 2016.

Twomey, S.: The influence of pollution on the shortwave albedo of clouds, J., Atmos. Sci., 34, 1149-1152, 1977.
Vana, M., Komsaare, K., Hõrrak, U., Mirme, S., Nieminen, T., Kontkanen, J., Manninen, H. E., Petäjä, T., Noe, S. M., and Kulmala, M.: Characteristics of new-particle formation at three SMEAR stations, Boreal Environ. Res., 21, 345-362, 2016.

van Meeningen, Y., Schurgers, G., Rinnan, R., and Holst, T.: BVOC emissions from English oak (Quercus robur) and European beech (Fagus sylvatica) along a latitudinal gradient, Biogeosciences, 13, 6067-6080, https://doi.org/10.5194/bg-13-6067-2016, 2016.

Vapaavuori, E., Holopainen, J. K., Holopainen, T., Julkunen-Tiitto, R., Kaakinen, S., Kasurinen, A., Kontunen-Soppela, S., Kostiainen, K., Oksanen, E., Peltonen, P., Riikonen, J., and Tulva, I.: Rising atmospheric $\mathrm{CO}_{2}$ concentration partially masks the negative effects of elevated $\mathrm{O}_{3}$ in silver birch (Betula pendula roth), Ambio, 38, 418-424, https://doi.org/10.1579/0044-744738.8.418, 2009.

Verlinden, M. S., Broeckx, L. S., Van den Bulcke, J., Van Acker, J., and Ceulemans, R.: Comparative study of biomass determinants of 12 poplar (Populus) genotypes in a high-density short-rotation culture, Forest Ecol. Manag., 307, 101-111, https://doi.org/10.1016/j.foreco.2013.06.062, 2013.

Vialle, A., Frey, P., Hambleton, S., Bernier, L., and Hamelin, R. C.: Poplar rust systematics and refinement of Melampsora species delineation, Fungal Divers., 50, 227-248, https://doi.org/10.1007/s13225-011-0129-6, 2011.

Voegele, R. T. and Mendgen, K.: Rust haustoria: nutrient uptake and beyond, New Phytol., 159, 93-100, https://doi.org/10.1046/j.1469-8137.2003.00761.x, 2003.

Waring, P. and Townsend, M.: Field Guide to the Moths of Great Britain and Ireland, British Wildlife Publishing, London, UK, 2009.

Wells, K. C., Millet, D. B., Payne, V. H., Deventer, M. J., Bates, K. H., de Gouw, J., Graus, M., Warneke, C., Wisthaler, A., and Fuentes, J. D.: Satellite isoprene retrievals constrain emissions and atmospheric oxidation, Nature, 585, 225-233, https://doi.org/10.1038/s41586-020-2664-3, 2020.

Williamson, C. J., Kupc, A., Axisa, D., Bilsback, K. R., Bui, T., Campuzano-Jost, P., Dollner, M., Froyd, K. D., Hodshire, A. L., Jimenez, J. L., Kodros, J. K., Luo, G., Murphy, D. M., Nault, B. A., Ray, E. A., Weinzierl, B., Wilson, J. C., Yu, F., Yu, P., Pierce, J. R., and Brock, C. A.: A large source of cloud condensation nuclei from new particle formation in the tropics, Nature, 574, 399-403, https://doi.org/10.1038/s41586-019-1638-9, 2019.

Winterhalter, R., Herrmann, F., Kanawati, B., Nguyen, T. L., Peeters, J., Vereecken, L., and Moortgat, G. K.: The gasphase ozonolysis of $\beta$-caryophyllene (C15H24), Part I: an experimental study, Phys. Chem. Chem. Phys., 11, 4152-4172, https://doi.org/10.1039/B817824K, 2009.

Yan, C., Nie, W., Vogel, A. L., Dada, L., Lehtipalo, K., Stolzenburg, D., Wagner, R., Rissanen, M. P., Xiao, M., Ahonen, L., Fischer, L., Rose, C., Bianchi, F., Gordon, H., Simon, M., Heinritzi, M., Garmash, O., Roldin, P., Dias, A., Ye, P., Hofbauer, V., Amorim, A., Bauer, P. S., Bergen, A., Bernhammer, A.-K., Breitenlechner, M., Brilke, S., Buchholz, A., Buenrostro Mazon, S., Canagaratna, M. R., Chen, X., Ding, A., Dommen, J., Draper, D. C., Duplissy, J., Frege, C., Heyn, C., Guida, R., Hakala, J., Heikkinen, L., Hoyle, C. R., Jokinen, T., Kangasluoma, J., Kirkby, J., Kontkanen, J., Kürten, A., Lawler, M. J., Mai, H., Mathot, S., Maulding III, R. L., Molteni, U., Nichman, L., Nieminen, T., Nowak, J., Ojdanic, A., Onnela, A., Pajunoja, A., Petäjä, T., Piel, 
F., Quéléver, L. L. J., Sarnela, N., Schallhart, S., Sengupta, K., Sipilä, M., Tomé, A., Tröstl, J., Väisänen, O., Wagner, A. C., Ylisirniö, A., Zha, Q., Baltensperger, U., Carslaw, K. S., Curtius, J., Flagan, R. C., Hansel, A., Riipinen, I., Smith, J. N., Virtanen, A., Winkler, P. M., Donahue, N. M., Kerminen, V.-M., Kulmala, M., Ehn, M., and Worsnop, D. R.: Size-dependent influence of NOx on the growth rates of organic aerosol particles, Sci. Adv., 6, eaay4945, https://doi.org/10.1126/sciadv.aay4945, 2020.

Ye, J., Jiang, Y., Veromann-Jürgenson, L.-L., Niinemets, Ü.: Petiole gall aphid (Pemphigus spyrothecae) infestation of Populus $\times$ petrovskiana leaves alters foliage photosynthetic characteristics and leads to enhanced emissions of both constitutive and stress-induced volatiles, Trees, 33, 37-51, https://doi.org/10.1007/s00468-018-1756-2, 2019.

Yli-Juuti, T., Riipinen, I., Aalto, P. P., Nieminen, T., Maenhaut, W., Janssens, I. A., Claeys, M., Salma, I., Ocskay, R., Hoffer, A., Imre, K., and Kulmala, M.: Characteristics of new particle formation events and cluster ions at K-puszta, Hungary, Boreal Environ. Res., 14, 683-698, 2009.

Yli-Juuti, T., Nieminen, T., Hirsikko, A., Aalto, P. P., Asmi, E., Hõrrak, U., Manninen, H. E., Patokoski, J., Dal Maso, M., Petäjä, T., Rinne, J., Kulmala, M., and Riipinen, I.: Growth rates of nucleation mode particles in Hyytiälä during 20032009: variation with particle size, season, data analysis method and ambient conditions, Atmos. Chem. Phys., 11, 12865-12886, https://doi.org/10.5194/acp-11-12865-2011, 2011.

Yli-Pirilä, P., Copolovici, L., Kännaste, A., Noe, S., Blande, J. D., Mikkonen, S., Klemola, T., Pulkkinen, J., Virtanen, A., Laaksonen, A., Joutsensaari, J., Niinemets, Ü., and Holopainen, J. K.: Herbivory by an outbreaking moth increases emissions of biogenic volatiles and leads to enhanced secondary organic aerosol formation capacity, Environ. Sci. Technol., 50, 11501-11510, https://doi.org/10.1021/acs.est.6b02800, 2016.

Ylisirniö, A., Buchholz, A., Mohr, C., Li, Z., Barreira, L., Lambe, A., Faiola, C., Kari, E., Yli-Juuti, T., Nizkorodov, S. A., Worsnop, D. R., Virtanen, A., and Schobesberger, S.: Composition and volatility of secondary organic aerosol (SOA) formed from oxidation of real tree emissions compared to simplified volatile organic compound (VOC) systems, Atmos. Chem. Phys., 20, 5629-5644, https://doi.org/10.5194/acp-205629-2020, 2020.
Ylivinkka, I., Itämies, J., Klemola, T., Ruohomäki, K., Kulmala, M., and Taipale, D.: Investigating evidence of enhanced aerosol formation and growth due to autumnal moth larvae feeding on mountain birch at SMEAR I in northern Finland, Boreal Environ. Res., 25, 121-143, 2020.

Yu, H., Ortega, J., Smith, J. N., Guenther, A. B., Kanawade, V. P., You, Yi., Liu, Y., Hosman, K., Karl, T., Seco, R., Geron, C., Pallardy, S. G., Gu, L., Mikkilä, J., and Lee, S.-H.: New particle formation and growth in an isoprene-dominated Ozark forest: from sub-5 nm to CCN-active sizes, Aerosol Sci. Technol., 48, 1285 1298, https://doi.org/10.1080/02786826.2014.984801, 2014.

Zannoni, N., Gros, V., Lanza, M., Sarda, R., Bonsang, B., Kalogridis, C., Preunkert, S., Legrand, M., Jambert, C., Boissard, C., and Lathiere, J.: $\mathrm{OH}$ reactivity and concentrations of biogenic volatile organic compounds in a Mediterranean forest of downy oak trees, Atmos. Chem. Phys., 16, 1619-1636, https://doi.org/10.5194/acp-16-1619-2016, 2016.

Zhao, D., Pullinen, I., Fuchs, H., Schrade, S., Wu, R., Acir, I.-H., Tillmann, R., Rohrer, F., Wildt, J., Guo, Y., Kiendler-Scharr, A., Wahner, A., Kang, S., Vereecken, L., and Mentel, T. F.: Highly oxygenated organic molecule (HOM) formation in the isoprene oxidation by $\mathrm{NO}_{3}$ radical, Atmos. Chem. Phys., 21, 9681-9704, https://doi.org/10.5194/acp-21-9681-2021, 2021.

Zúbrik, M., Novotný, J., and Kozánek, M.: The effect of gamma radiation on the host preferences of the gypsy moth larvae (Lymantria dispar L., Lep.: Lymantriidae), Lesn. Čas. For. J., 53, 15-23, 2007. 